UNIVERSIDADE DE SÃO PAULO

ESCOLA DE ARTES, CIÊNCIAS E HUMANIDADES

PROGRAMA DE PÓS-GRADUAÇÃO EM ESTUDOS CULTURAIS

VANESSA SIMON DA SILVA

\title{
$O$ grotesco e o monstruoso entre culturas: do discurso científico aos folhetos de cordel brasileiros
}

São Paulo

2016 


\title{
O grotesco e o monstruoso entre culturas: do discurso científico aos folhetos de cordel brasileiros
}

\author{
Dissertação apresentada à Escola de Artes, Ciências e \\ Humanidades da Universidade de São Paulo, para a obtenção do \\ título de Mestre em Filosofia pelo Programa de Pós-Graduação \\ em Estudos Culturais. \\ Área de Concentração: Estudos Culturais \\ Orientador: Prof. Dr. Thomás Augusto Santoro Haddad
}

São Paulo

2016

Versão corrigida. Original disponível para consulta na Biblioteca da EACH/USP. 
Autorizo a reprodução e divulgação total ou parcial deste trabalho, por qualquer meio convencional ou eletrônico, para fins de estudo e pesquisa, desde que citada a fonte.

CATALOGAÇÃO-NA-PUBLICAÇÃO

(Universidade de São Paulo. Escola de Artes, Ciências e Humanidades. Biblioteca)

Silva, Vanessa Simon da

O grotesco e o monstruoso entre culturas : do discurso científico aos folhetos de cordel brasileiros / Vanessa Simon da Silva

orientador, Thomás Augusto Santoro Haddad. - São Paulo, 2016 $117 \mathrm{f}$. : il

Dissertação (Mestrado em Filosofia) - Programa de Pós-

Graduação em Estudos Culturais, Escola de Artes, Ciências e Humanidades, Universidade de São Paulo

Versão corrigida

1. Literatura de cordel - Brasil. 2. Monstros. 3. Cultura. 4. Grotesco. 5. Semiologia da imagem. I. Haddad. Thomas Augusto Santoro, orient. II. Título

CDD 22.ed. - 398.50981 
Nome: Silva, Vanessa Simon da

Título: O grotesco e o monstruoso entre culturas: do discurso científico aos folhetos de cordel brasileiros

Aprovada em: 16/02//2016

\section{Banca Examinadora}

Profa. Dra. Palmira Fontes da Costa

Instituição: Universidade Nova de Lisboa

Prof. Dr. Paulo Teixeira Iumatti

Instituição: Universidade de São Paulo

Prof. Dr. Carlos Henrique Barbosa Gonçalves

Instituição: Universidade de São Paulo 


\section{AGRADECIMENTOS}

Ao amigo Pablo Ortellado, que me apresentou o Programa de Estudos Culturais e teve participação decisiva na decisão de nele ingressar.

Ao Professor Rogério Monteiro, que na coordenação do Programa se mostrou sempre solícito diante das mais variadas demandas.

À Professora Palmira Costa, que gentilmente aceitou receber-me na Universidade Nova de Lisboa.

Ao Professor Carlos Gonçalves, que repetidas vezes dedicou seu tempo e atenção em conversas sobre anormalidades de tempos e espaços distantes.

Ao Professor Paulo Iumatti, pelos conselhos e pelo intermédio junto à Universidade de Poitiers.

A toda a equipe do acervo Raymond Cantel.

À Equipe do IEB, especialmente a Gabriela Cardoso e a Elisabete Ribas, exemplo inspirador de profissional, exímia conhecedora de cada caixa presente em seu arquivo, além de profundamente comprometida com o mais fluido acesso à informação e com o melhor atendimento aos pesquisadores.

À amiga Fernanda Augusta, que me recebeu nas empreitadas pelo Rio de Janeiro.

À amiga Juliana Cristina, pela recepção no ENECULT 2015.

À amiga Salete Perroni, pelo companheirismo, pelo encorajamento no momento da radical mudança nos rumos da pesquisa e por ter feito parte de todo este processo. 
À irmã que a vida permitiu escolher, Carolina Costa, pela presença, apoio e pelo suporte imensuráveis.

Aos amigos Nádia Gonfiantini e Waldir Rocha, pela acolhida em Paris.

Aos amigos Zé (Márcio Pedroso) e Maurício Rodrigues, por todo tipo de suporte.

Às amigas Sabrina Veloso, Mariana Telles e Marisa Villi e ao amigo Fausto Oi, pelo apoio, interesse e contribuições de toda ordem.

Ao amigo Helton (Bastos) Saragor, amigo de tantos anos, pelo ouvido disposto e pelas longas conversas sobre meio acadêmico.

Ao querido Luiz, pelo interesse, carinho e atenção.

Aos muitos amigos que não aparecem aqui, mas que, direta ou indiretamente, contribuíram para que esta dissertação se desenvolvesse.

E, finalmente, ao professor e amigo, Thomás Haddad, que me orientou ao longo desta jornada, acompanhando de perto os sofrimentos e as alegrias que dela fizeram parte.

Este trabalho teve apoio financeiro da Capes. 
Gregório não tivera a menor intenção de assustar fosse quem fosse, e muito menos a irmã. Tinha simplesmente começado a virar-se, para rastejar de regresso ao quarto. Compreendia que a operação devia causar medo, pois estava tão diminuído que só lhe era possível efetuar a rotação erguendo a cabeça e apoiando-se com ela no chão a cada passo.

Franz Kafka, A Metamorfose, 1915. 


\section{RESUMO}

SILVA, V. S. O grotesco e o monstruoso entre culturas: do discurso científico aos folhetos de cordel brasileiros. 2016. 117 páginas. Dissertação (Mestrado em Estudos Culturais) Escola de Artes, Ciências e Humanidades, Universidade de São Paulo, São Paulo, 2016.

Seres insólitos estiveram presentes no cordel europeu, especialmente entre os séculos XVIII e XIX, alimentando debates sobre verossimilhança, fé, ciência e política. Mais de um século depois, o fenômeno do cordel arrefece na Europa, mas tem vida no Brasil. Parte desses folhetos trata de criaturas insólitas, especialmente transformações, ou nascimentos extraordinários, abordados como curiosidade ou, mais frequentemente, relacionados à intervenção divina. Ainda que nem sempre datados, é possível presumir que os exemplares coletados para este trabalho tenham sido publicados entre as décadas de 1960 e 1980. Neles, a aparição de monstros é frequente e se situa principalmente entre o satírico e o religioso.

Palavras-chave: Literatura de Cordel - Brasil; Monstros; Cultura; Grotesco; Semiologia da Imagem. 


\begin{abstract}
SILVA, V. S. The grotesque and the monstrous between cultures: from scientific discourse to Brazilian chapbooks. 2016. 117 pages. Dissertation (Master's in Cultural Studies) - Escola de Artes, Ciências e Humanidades, Universidade de São Paulo, São Paulo, 2015.

Uncanny beings were present in European chapbooks, especially during the eighteenth and nineteenth centuries, stimulating debates concerning verisimilitude, faith, science and politics. Over a century later, the chapbook phenomenon loses strength in Europe but gains life in Brazil. Some of these brochures deal with uncanny creatures, mainly metamorphoses, or bizarre births, considered as curiosities or, more frequently, as results of divine intervention. Even though they may not bear a date, it can be presumed that the chapbooks analyzed in this dissertation were published from the 1960s to the 1980s. Monsters appear quite frequently in this material, in registers that are situated mainly between the satirical and the religious.
\end{abstract}

Keywords: Chapbooks ("literatura de cordel") - Brazil; Monsters; Culture; Grotesque; Semiology of Images. 


\section{LISTA DE FIGURAS}

\section{Capas de Cordéis:}

Figura $1 \mathrm{O}$ menino que nasceu barbado, de Severino Gonçalves de Oliveira 87

Figura 2 A menina que nasceu em Minas Gerais, com quatro olhos, duas bôcas, duas ventas, 4 orelhas e 10 dedos em cada mão, as suas palavras viveram 48 dias e falou, de Gilberto Severino Francisco.

Figura 3 A menina fenômeno foi moça com 10 meses, em Arapiraca, de José Soares.......... 87

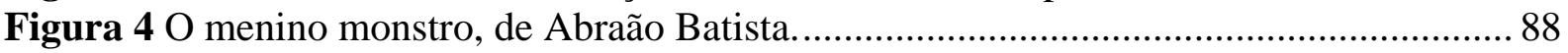

Figura 5 A mulher que deu a luz a um satanaz, de José Soares........................................... 88

Figura 6 O menino que nasceu com a cabeça nas constas, de José Francisco Soares. ........... 89

Figura $7 \mathrm{O}$ menino que nasceu com a pintura do cão, de Manoela Caboblo e Silva.............. 89

Figura 8 A moça que virou jumenta porque falou de top less com Frei Damião, de José Francisco Borges. 90

Figura $9 \mathrm{O}$ encontro da crente que virou besta com o crente que virou jumento, de João de Barros. 90

Figura 10 Protestante que virou num urubu porque quiz matar Frei Damião, de Manoel Serafim Ventura.

Figura 11 A moça que virou cachorro porque deu banana ao padre Frei Damião, de J. J. Andrade.

Figura 12 O rapaz que virou cachorro poque zombou do padre Cícero Romão, de João de

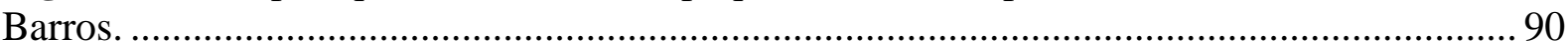

Figura 13 A mulher que virou cobra por zombar de Frei Damião, de Pedro Bandeira. ......... 90

Figura 15 O homem macaco ou o lubisomem do cabo, de José Soares............................... 92

Figura 17 A lâmpada de Aladim, de Antonio Gonçalves (Patativa do Assaré)...................... 92

Figura 18 Mensageira do diabo ou "a mulher vampiro", de João de Barros. .......................... 93

Figura 19 História de Luizinho e o velho feiticeiro, de Vicente Vitorino de Melo. .............. 93

Figura 20 Raquel e a fera encantada, de José Bernardo da Silva......................................... 94

Figura 21 Juvenal e o dragão, de José Bernardo da Silva.................................................... 94

Figura $22 \mathrm{O}$ filho de Juvenal e o dragão vermelho, de Expedito F. Silva. ............................ 94

Figura 24 Mensageira do diabo ou "a mulher vampiro", de João de Barros. ......................... 95

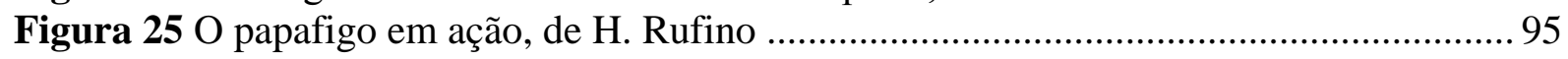

Figura 26 Cavalo encantado, coleção Ruth Terra ............................................................... 96

Figura 27 O cavalo voador ou Juliêta e Custódio, de José Costa Leite. ................................ 96

Figura 28 A mulher de sete metros que apareceu em Itabuna - Estado da Bahia, de Minelvino

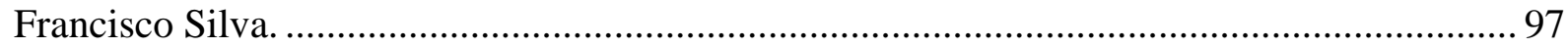

Figura 29 A mulher de quatro metros que anda de feira em feira, de Rodolfo Coelho

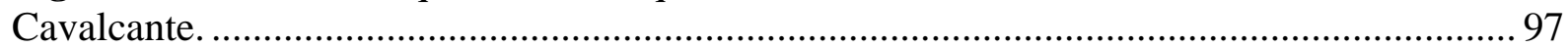

Figura 30 A prisão do gigante da montanha assombrosa, de Minelvino Francisco Silva. ..... 97

\section{Outras:}

Figura 1a Detalhe do quadro A tentação de Santo Antônio, de Hieronymus Bosch, 1504. 
Figura 2a Detalhe do quadro Martírio de Sto. Antônio no retábulo de Isenheim, de

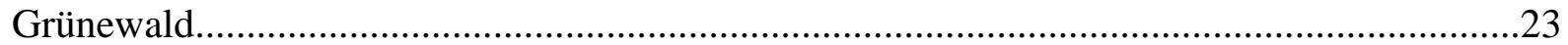

Figura 3a Fauna do Brasil em meados do século XVIII, segundo Nielhoff..........................27

Figura 4a "Emblema vivente, ou notícia de hum portentoso monstro, que da Província de Anatólia foy mandado ao Sultão dos Turcos. Com a sua figura, copiada do retrato, que delle mandou fazer o Biglerbey de Amafia, recebida de Alepo, em huma carta escrita pelo

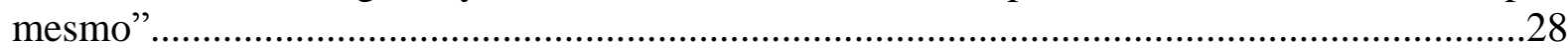

Figura 14 Retratos dos monstros de Schloss Ambras. À esquerda, Petrus Gonçalvus, à direita, sua filha 92

Figura 16 Dessins pour le Cabinet des fées Marillier, Clément-Pierre (1740-1808)..... . .92

Figura 23 Imagem do altar de Marta presente na Igreja St. Lorenz, em Nuremberg (Alemanha), mostrando a santa com uma Tarasca. 


\section{Sumário}

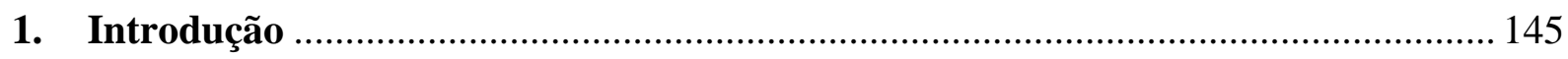

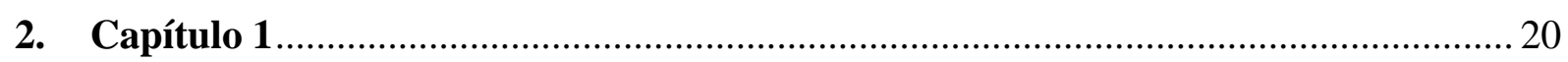

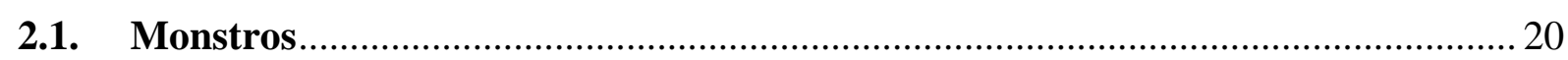

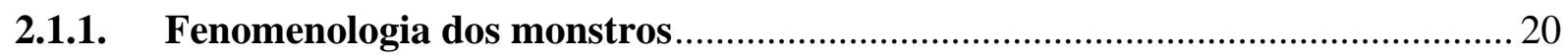

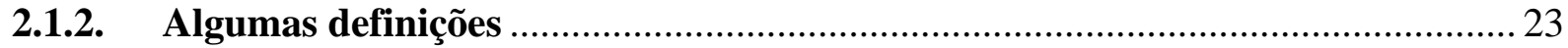

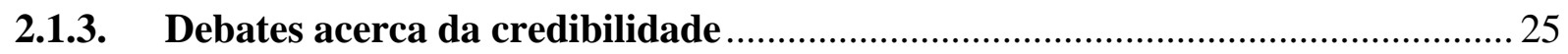

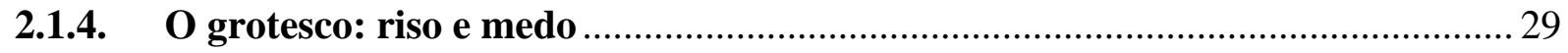

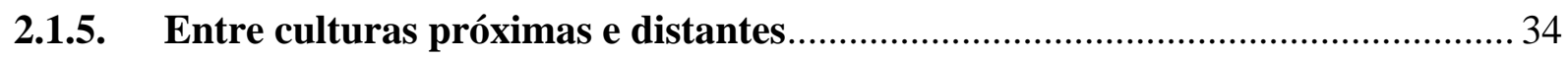

2.1.6. Tradições explicativas acerca de seres monstruosos ........................................... 35

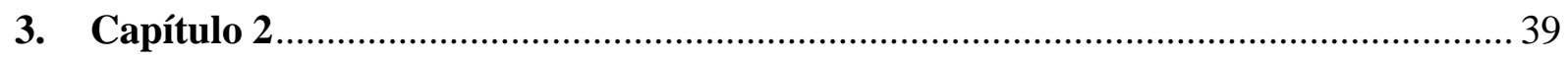

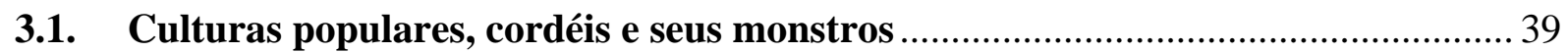

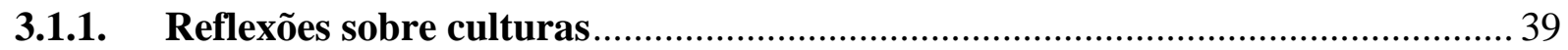

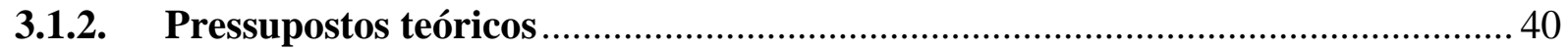

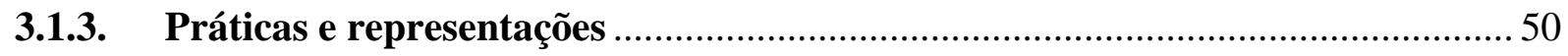

3.1.4. Definindo e localizando o cordel ...................................................................... 53

3.1.5. A cara do Brasil e um nordeste multifacetado .................................................... 56

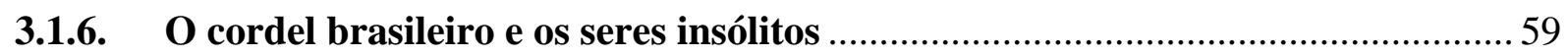

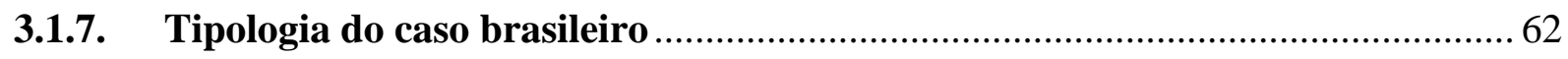

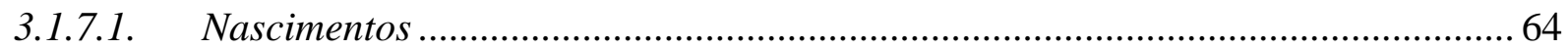

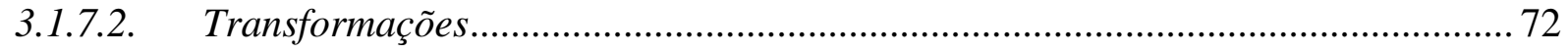

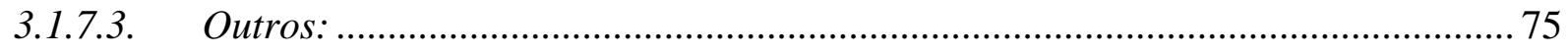

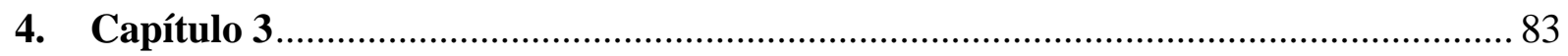

4.1. A xilogravura no cordel brasileiro: aproximações e afastamentos......................... 83

4.2. Considerações acerca das capas de alguns folhetos .......................................... 87

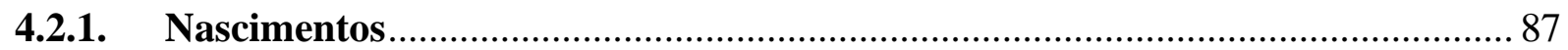

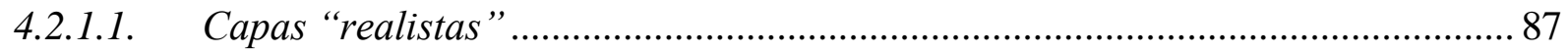

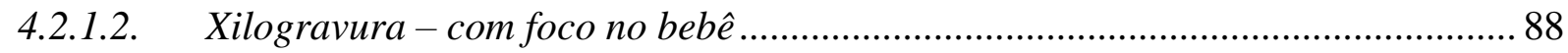

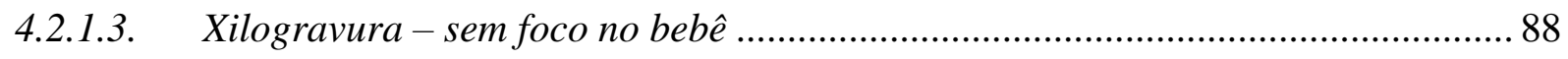

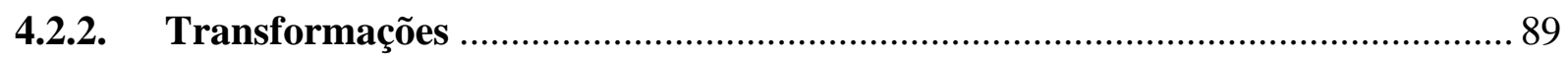

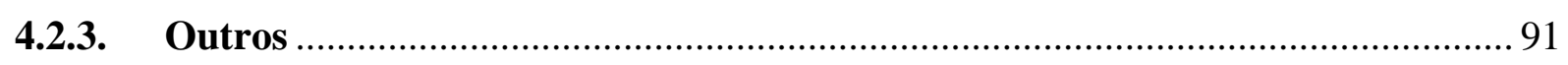

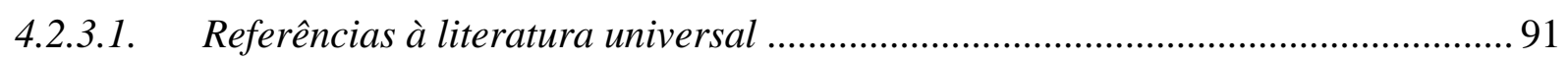

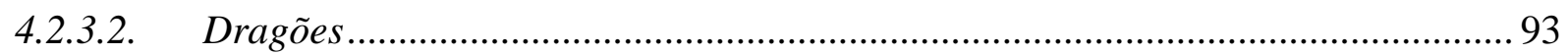

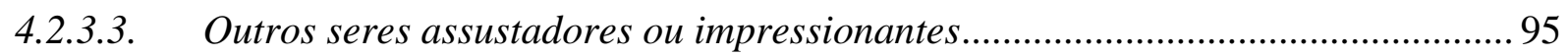

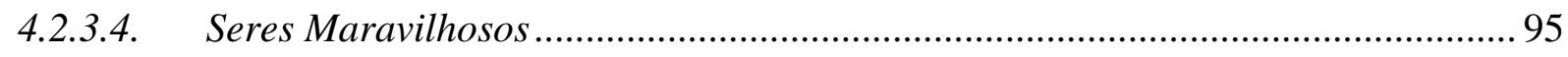

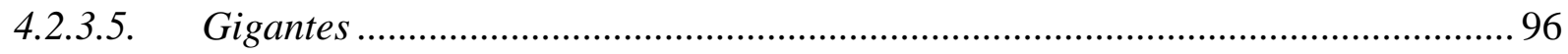




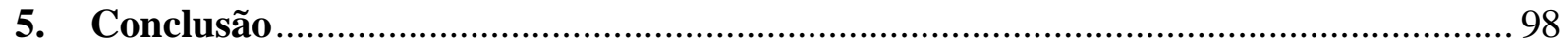

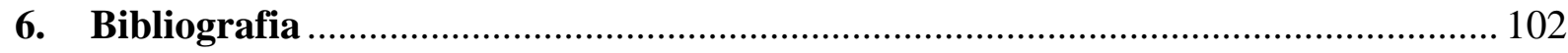

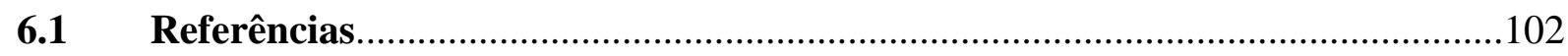

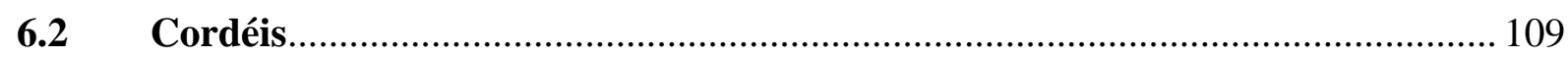




\section{Aviso aos leitores}

Ainda que não tenha sido possível viabilizar a troca em tempo hábil, conforme os trâmites do Programa de Estudos Culturais é oportuno chamar atenção para o título desta dissertação, que já não corresponde ao desenvolvimento da pesquisa. A análise do material apresentado colocou em posição secundária o discurso científico no tratamento do corpo insólito no cordel brasileiro. Assim, o título que melhor representaria seu conteúdo seria simplesmente "Monstros na literatura de cordel brasileira" e esperamos que a pesquisa possa ser lida à luz desta informação. 


\section{Introdução}

“Os Estudos Culturais consistem em um pensamento sem garantias": é o que afirma o pesquisador colombiano Eduardo Restrepo em seu texto "Estudios culturales en América Latina”, publicado pela revista do Programa de Estudos Culturais e discutido no Seminário Internacional promovido também pelo Programa em março de 2014 nesta Escola.

Retomo a afirmativa no intuito de refletir acerca de aprendizados que se fizeram possíveis no desenrolar da dissertação a ser tratada: o exercício da livre experimentação, seus perigos e seus ganhos. Impossível no âmbito da mais tradicional disciplinaridade, esta pesquisa permitiu-se observar seus objetos de modo pouco usual, tanto para a história, quanto para a literatura, e transitou por espinhosas searas no intuito de tentar constituir uma visão panorâmica de algo que se daria na interação entre um recorte temático amplo, o monstro, e o cordel brasileiro, um tipo de suporte bastante vasto em títulos, autores e categorizações.

Procurar ocorrências relativas à monstruosidade no corpo vasto de uma modalidade literária não canônica, e não de um autor, de uma geração, ou de um ciclo específico, pode, inicialmente, ter causado estranheza aos que tiveram contato com a pesquisa. Por outro lado, somente o recorte sobre coleções e não sobre artistas ou ciclos permitiu uma visão panorâmica das edições e revelou o corpo monstruoso, não como tema central de um artista em específico, mas como assunto comum a grande número de folhetos que interseccionam ciclos e gerações. Parece seguro supor que os poetas tenham catalisado um recorrente interesse de seu público consumidor em torno da temática referida e que este interesse tenha garantido a recorrência do tema.

Objeto e suporte revelaram uma riquíssima e promissora união da qual emergiu o verdadeiro problema de fundo desta dissertação que, a certa altura, já não era nem o cordel, nem os monstros em si, mas aquilo que se revela sobre culturas a partir da intersecção de ambos.

Mais uma vez, vale lembrar que os Estudos Culturais constituíram uma tendência importante da crítica que questiona o estabelecimento de hierarquias entre formas e práticas culturais determinadas a partir de oposições como cultura alta/baixa, superior/inferior. 
Embora tenham se pautado em discussões contrárias aos binarismos e à guerra contra os cânones, fronteiras disciplinares e muros acadêmicos, não se caracterizam por uma única teoria ou metodologia unificada. E é no interesse pelos estudos menos tradicionais que os métodos de pesquisa se fazem mais experimentais e desafiadores.

Tendo assumido os riscos desta empreitada já é possível, com algum distanciamento, identificar abordagens merecedoras de releitura em meu próprio trabalho, conexões que ficaram por ser estabelecidas, reflexões deixadas um tanto em aberto, ou a opção por autores que de alguma forma ainda inquietam. Muito das ideias presentes nesta dissertação se constituíram a partir do contato com materiais que surgiram somente em seu processo de finalização. Consciente dos prejuízos que certas mudanças de rumos gerariam, apostei na pesquisa de arquivo e na emergência de tentar compreender autores que até então não haviam aparecido, mas cuja incorporação urgia. A primeira releitura revelou, por exemplo, a necessidade de renomear a dissertação, visto que seus rumos se distanciaram de uma ideia inicial em que a relação entre a cultura médica e o corpo insólito estivessem mais associados no cordel brasileiro. A mudança não foi possível, no entanto, compreendo hoje que o melhor título para esta dissertação seria simplesmente "Monstros na literatura de cordel brasileira". Passemos assim a uma sucinta apresentação do virá.

Gigantes, ciclopes, minotauros, medusas e sereias na literatura clássica; estranhos seres retratados nas telas de Bosch e de Brueghel; as gárgulas da arquitetura gótica; Frankenstein na literatura de terror e no cinema: apenas alguns exemplos das inúmeras aparições de seres fantásticos, terríveis ou prodigiosos que povoaram as artes e a imaginação, desde muito antes da Era Cristã até a contemporaneidade. Alguns deles seres grotescos, monstruosos, ou tão somente insólitos, foram associados a maravilhas, ao medo, mas também ao riso. O interesse pelo fenômeno do monstruoso estendeu-se pelo campo da ciência e teve grande destaque nos séculos XVI e XVII, conservando-se, ainda que de modo menos evidente, ao longo do Século das Luzes ${ }^{1}$. Na literatura de cariz popular, por sua vez, os seres monstruosos mantiveram volumosa presença. Discursos científicos, teológicos e estéticos, nos registros eruditos e populares, variavam e se reinventavam, influenciando-se mutuamente. No plano da medicina, relatos e ilustrações eram, com frequência, ferramentas

\footnotetext{
${ }^{1}$ Segundo a pesquisadora Palmira Fontes da Costa monstros povoaram a literatura médica portuguesa mesmo neste período.
} 
únicas na constituição da verossimilhança de muitas das ocorrências monstruosas, dada sua raridade. Nesse caso, a ciência encontrou suas fontes e seus limites no imaginário e na cultura popular. Esta é uma das discussões presentes no primeiro dos três capítulos que compõem esta dissertação.

A pesquisa nasceu de um interesse primordial por seres insólitos retratados nos mais diversos tempos e realidades. Esta multiplicidade de discursos em torno do tema chamou atenção para sua amplitude transversal, que revela afastamentos, aproximações, trocas culturais e mesclas, das mais evidentes às mais inusitadas no que tange seu tratamento.

A partir daí começou a busca por um suporte que abarcasse a temática em questão e estivesse mais próximo de minha realidade cultural, ou melhor, de realidades culturais múltiplas que compuseram minha noção de Brasil. Em pouco tempo emergiu o cordel como material rico em relatos do corpo insólito e, assim como os monstros, repleto de marcas da circularidade cultural ${ }^{2}$. Tema e suporte revelaram uma riquíssima e promissora união da qual emergiu o verdadeiro problema de fundo desta dissertação: uma preocupação com a compreensão de cultura popular, seus conteúdos e suas formas.

Quanto a constituição do corpus, algumas dificuldades iniciais acabaram por definir especialmente três fontes de busca, escolhidas em função de sua maior disponibilidade no período de coleta desta pesquisa: Acervo Raymond Cantel, localizado na Universidade de Poitiers, na França e as coleções Ruth Terra e Gilmar de Carvalho, alocadas no Instituto de

2 Quanto ao uso da expressão "circularidade cultural", no caso deste trabalho, vale ressaltar que o cordel brasileiro foi marcado por inúmeras referências externas - algumas apontadas por esta dissertação - mas também deixou suas marcas neste espaço "externo", a exemplo do que pode ser observado no que se refere a seu impacto na cultura de massas. Seria este o caso de João Grilo, personagem da literatura portuguesa, ressignificado por Leandro Gomes de Barros. Grilo foi protagonista de uma das mais importantes peças de Ariano Suassuna, “A compadecida". A adaptação rendeu versões para o cinema e televisão: $O$ Auto da Compadecida (minissérie), O Auto da Compadecida (filme), A Compadecida (filme de 1969), Os Trapalhões no Auto da Compadecida (filme de 1987) - João Grilo retorna ainda como personagem de cordéis contemporâneos. Este é apenas um exemplo entre muitos que envolvem a circularidade inscrita sobre os folhetos de cordel. 
Estudos Brasileiros da Universidade de São Paulo. Mais de 200 folhetos foram inicialmente selecionados, ainda sem claros contornos ou obediência a critérios relacionados a grupos temáticos. Também foram observados folhetos de outras origens, especialmente portugueses. No entanto,

\begin{abstract}
A tensão se organiza - com frequência conflituosamente - entre a paixão de recolher o arquivo inteiro, de tudo ler, de brincar com seu lado espetacular e seu conteúdo ilimitado, e a razão, que exige que ele seja finalmente questionado para ganhar sentido. (FARGE, 1989:22)
\end{abstract}

Assim, conforme a pesquisa de arquivo apontava para possibilidades mais solidamente verificáveis, surgiu o objetivo de ilustrar amostragens organizadas em três grupos temáticos - nascimentos, transformações e um apanhado geral de aparições diversas denominado "outros" - 92 folhetos passaram a compor o corpus desta dissertação.

O Capítulo 1 trata de diversas acepções culturais acerca da monstruosidade. Aborda a estética do grotesco, a fenomenologia dos monstros, as relações entre o riso e o medo, o olhar científico e o religioso sobre seres insólitos e a própria atualidade do tema. O trânsito entre diferentes esferas do saber na construção de tais conhecimentos norteia a configuração, não apenas deste, mas também dos demais capítulos.

O Capítulo 2, apresenta uma série de questões referentes a ideia de cultura popular e procura refletir sobre o contexto em que estão inseridos os folhetos de cordel brasileiros. Propõe a classificação tipológica para os títulos selecionados, conforme mencionado.

. Folhetos de diversos autores foram observados e alguns poetas de grande expressão no universo do cordel se destacam por conta da predileção pelo assunto. É o caso de artistas, como Jota Barros, Abraão Batista, José Soares e Minelvino Silva. Um apanhado de folhetos, considerados adequados para demonstração de determinadas recorrências tiveram trechos suscintamente analisados com o objetivo de ilustrar alguns dos apontamentos sugeridos por esta pesquisa.

Nestes folhetos, os trânsitos entre o cômico e o sagrado desorganizaram as fronteiras entre "popular" e "erudito": A abordagem humorística de elementos sacros, tanto nas imagens quanto nos poemas, propõe certa resistência a uma compreensão dura de religião, 
transgredindo-a. Os valores da razão científica também são desorganizados diante das aparições extraordinárias, que por vezes oscilam entre apelos à verossimilhança e à comicidade. Não raro, o tom moralizante divide espaço com a irreverência e personagens da literatura universal convivem com cangaceiros e personalidades religiosas de grande popularidade como o Padre Cícero e o Frei Damião.

Finalmente, no Capítulo 3 há a tentativa de tratar, ainda que de maneira experimental e talvez um pouco incipiente, de elementos presentes no material empírico, ou seja, imagens que ilustram as capas dos folhetos, pensando em algumas de suas implicações estéticas, suas relações com os poemas, aspectos de humor e verossimilhança e, especialmente, nas relações que podem ser estabelecidas tanto para dentro quanto para fora do suporte, isto é, de que modo imagem e poema dialogam no mesmo folheto e de que forma a imagem transcende este diálogo.

Ainda no que tange ao cordel, os capítulo 2 e 3 procuram problematizar o discurso gestado na década de 1970, que contribuiu para um modo de compreensão do objeto ainda persistente entre muitos de seus pesquisadores e endossado, frequentemente, pela própria catalogação: sua associação direta ao "folclore" e não à "literatura brasileira".

De modo mais específico o objeto desta pesquisa não é nem o cordel, nem os monstros em si, mas aquilo que se revela sobre culturas a partir da intersecção entre ambos. Por isso esta dissertação não se localiza genuinamente nem no campo da história, nem no da literatura e, portanto, não deve ser lida com esses olhos.

Os Estudos Culturais constituíram uma tendência importante da crítica que questiona o estabelecimento de hierarquias entre formas e práticas culturais determinadas a partir de oposições como cultura alta/baixa, superior/inferior. Embora tenham se pautado em discussões contrárias aos binarismos e à guerra contra os cânones, fronteiras disciplinares e muros acadêmicos, não se caracterizam por uma única teoria ou metodologia unificada.

Finalmente, é preciso alertar os leitores para a natureza deste trabalho, aberta em desenvolvimento, logo, não deve ser lido como um texto finalizado, mas vivo e em transformação. 


\section{Capítulo 1}

\subsection{Monstros}

\subsubsection{Fenomenologia dos monstros}

Ignoramos el sentido del dragón, como ignoramos el sentido del universo, pero algo hay en su imagen que concuerda con la imaginación de los hombres, y así el dragón en distintas latitudes y edades. (BORGES, 1990.)

Claude Kappler buscou inspiração nas terrificantes obras de Bosch (fig. 1a) e em congêneres da época, como Grünewald (fig. 2a), para produzir sua obra sobre monstros e demônios no fim da Idade Média. Para ele o monstro subverte um universo organizado e que contrasta com sua intrínseca e desconcertante desorganização:

O monstro constitui um problema do qual não nos podemos esquivar: um mundo onde tudo é normal, onde tudo encontrou seu lugar, tanto do ponto de vista geométrico e espacial, quanto do ponto de vista espiritual, em última análise prescinde de comentário; o comentário não passa, em suma, de um discurso de ação de graças ou de uma paráfrase do universo, através dos quais a alma, animada por uma respiração cósmica, tende a aproximar-se de um conhecimento mais perfeito, num caminho cujo único obstáculo é a espessura da matéria. Mas o monstro propõe uma imagem subvertida dessa ordem; é simultaneamente mistério e mistificação. Ele desconcerta, e quanto mais organizado e hierarquicamente justificado é o universo, tanto mais gritante é o problema por ele apresentado. Ele não dispensa explicações: o enigma exige ser decifrado. (KAPPLER, 1994:15)

Ao tratar das tarefas de uma fenomenologia dos monstros (ou da monstruosidade), José Gil compreende que estes seres extrapolam os conteúdos inerentes a sua forma, origem ou causa:

Uma fenomenologia da monstruosidade revelaria sem dúvida que o fascínio provocado pela visão de um monstro, refere-se, em primeiro lugar, à superabundância de realidade que ele oferece ao olhar. Esbocemos alguns passos nessa direção. Um monstro é sempre um excesso de presença. Que a anomalia seja um corpo redundante ou a que faltem órgãos é necessariamente marcado por um 
excesso (...) como entidade não manifesta privações ou faltas; nunca um desses corpos sem cabeça das raças do Oriente é apreendido como menos que um homem, menos que um corpo diminuído. (...) É reconhecer implicitamente a pertinência e autonomia de criaturas, que apesar de privadas de algo, justificam a criação de uma categoria à parte, admitindo assim a sua paradoxal compleição. Ao minotauro não falta nem uma parte de homem, nem de touro; não é nem um-corpo-humano-semcabeça-que-possui-uma-cabeça-de-touro, nem uma cabeça-de-touro-suportadapor-um-corpo-de-homem. (...) O ciclope não é um ser ao qual falta um olho, mas um gigante que possui um olho na testa. (...) O transbordamento que o monstro veicula, ultrapassa o conteúdo representado, está para lá da sua origem e da sua causa (...). (GIL, 2006:74)

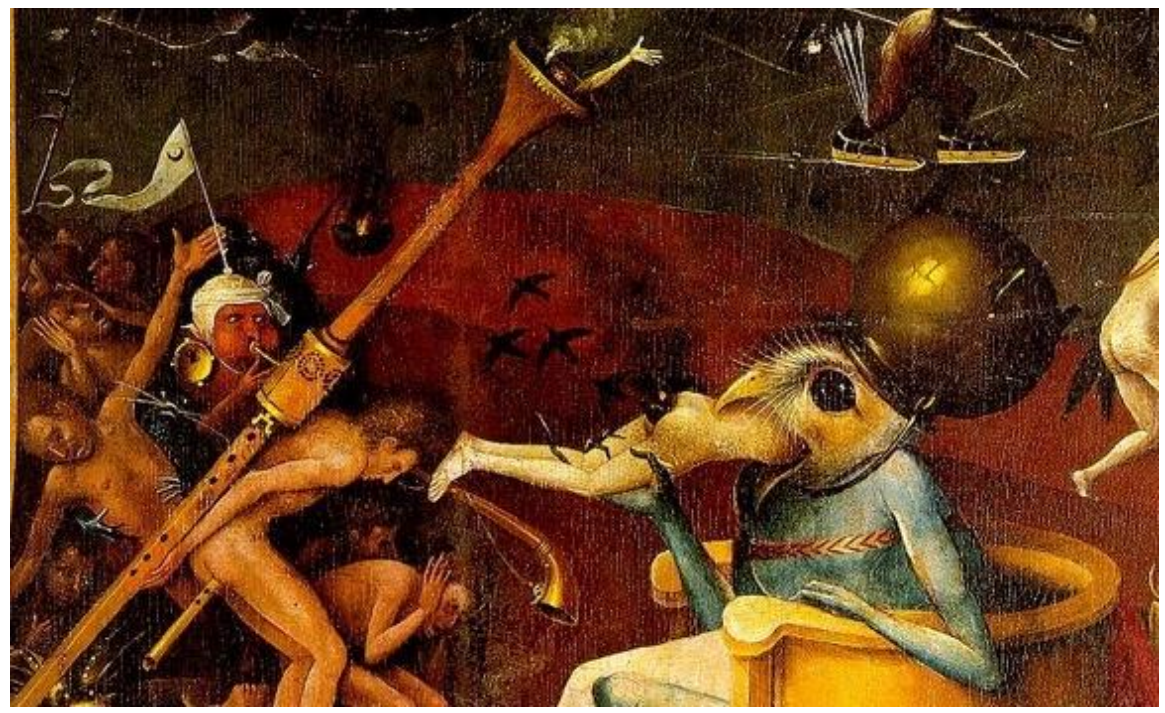

Figura 1a. Detalhe do quadro A tentação de Santo Antônio, de Hieronymus Bosch, 1504. (Fonte: Wikimedia Commons) 


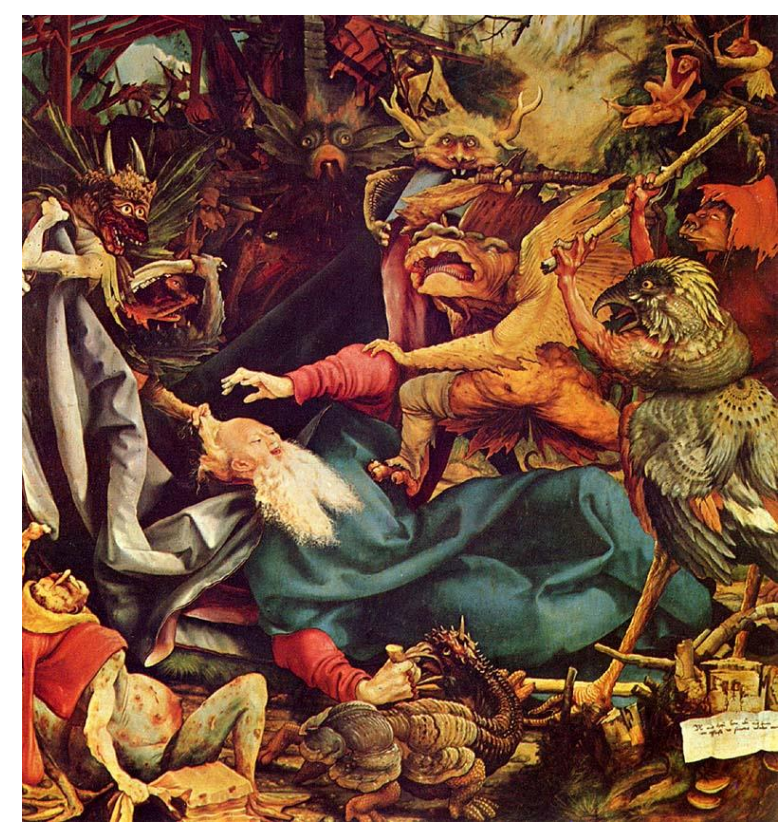

Figura 2a Martírio de Sto. Antônio no retábulo de Isenheim, de Grünewald. (Fonte: Wikimedia Commons)

Lorraine Daston e Katharine Park tratam da fascinação da cultura de elite da Europa Ocidental pelo misterioso e pelo raro. Neste bojo entram supostas raças humanas monstruosas oriundas da Ásia e da África, os nascimentos raros, como de gêmeos siameses, ou de bebês disformes, seres inicialmente entendidos como "maravilhas". No capítulo V da obra Wonders and the Order of Nature: 1150-1750 trata-se especificamente da questão dos monstros: o horror, o prazer e a repugnância - palavras definidoras do tratamento mais comumente dado a este tema, já que os seres insólitos eram tratados como "prodígios", "passatempos", ou "desvios da natureza". Pela idade do Iluminismo, no entanto, essas preocupações passam a ser consideradas banais pela elite cultural. As "maravilhas" continuam fazendo parte da cultura ocidental, mas os tabloides e revistas científicas já não as anunciam. Daston e Park chamam atenção ao fato de que, com tantas mudanças e preocupações relativas à percepção de seres insólitos, essas criaturas, longe de violarem leis naturais, movimentaram costumes e estruturas sociais:

The shift from norms of nature to norms of custom did not weaken the emotional charge of monsters. Rather both norms of nature and custom became more rigid in the early eighteenth. What had once been nature's habits hardened into inviolable 
laws; what had once been irregular and unpredictable public conduct hardened into a regimen of propriety and social rules. Monsters did not, could not, violate nature's laws, but in infringing upon society's customs, they cast doubt on the stability of both orders. (DASTON \& PARK, 1998: 214)

Seus estudos contribuíram para a compreensão do que tem sido um aspecto relativamente negligenciado da história intelectual europeia. As autoras demonstram que aquilo que por muito tempo foi visto como um aspecto periférico do pensamento europeu era parte do mainstream da história intelectual da Europa.

\subsubsection{Algumas definições}

Segundo o dicionário de símbolos de Jean Chevalier,

Monstruo. 1. El monstruo simboliza al guardián de un tesoro, como el tesoro de la inmortalidad por ejemplo, es decir, el conjunto de las dificultades a vencer, los obstáculos a superar, para acceder por último a ese tesoro, material, biológico o espiritual. El monstruo está allí para provocar el esfuerzo, el dominio del miedo, el heroísmo. Interviene en este sentido en numerosos ritos iniciáticos. Al sujeto corresponde presentar sus pruebas, dar la medida de sus capacidades y de sus méritos. Es necesario vencer el dragón. la serpiente, las plantas espinosas, toda especie de monstruo, incluido uno mismo, para poseer los bienes superiores que ansiamos. Los monstruos montan la guardia a la puerta de los palacios reales, de los templos y de las tumbas. En numerosos casos el monstruo no es efectivamente más que la imagen de un cierto yo, ese yo que conviene vencer para desarrollar un yo superior. El conflicto se simboliza a menudo en la imaginería antigua por el combate del águila y la serpiente. (CHEVALIER, s.v. "Monstruo")

As criaturas presentes nos folhetos de cordel aqui examinados serão tratadas como grotescas. Também as trataremos como "ínsólito", do latim insolitus, "não costumeiro, estranho", ou, conforme o dicionário Houaiss (2001), insólito: “1. que não é habitual; infrequente, raro, incomum, anormal; 2. que se opõe aos usos e costumes; que é contrário às regras, à tradição". Poderão ser chamadas ainda, e simplesmente, de "monstros", em função das irregularidades em seus aspectos físicos. O termo monstro gera certa controvérsia quanto a sua origem: teria surgido do latim monstrum, "aquele que mostra, adverte", ou de monere, 
que sugere a ideia de "avisar, chamar atenção para". Estas definições associam o poder divino à figura do monstro, que estaria servindo de meio para que algo fosse comunicado. José Gil, recorrendo ao linguista Benveniste, conclui que "monstro" se originou da palavra monstrare e que essa possui a ideia de "ensinar um comportamento, prescrever a via a seguir" (GIL, 2006:74). Afirma ainda que:

O monstro é, ao mesmo tempo, absolutamente transparente e totalmente opaco. Quando o encaramos, nosso olhar fica paralisado e absorto em um fascínio sem fim, inapto ao reconhecimento, pois este nada revela (...). No entanto, ao exibir sua deformidade (...) oferece ao olhar mais do que qualquer coisa já vista (GIL, 2006:78).

Para Émile Benveniste (1995: 257-265), a forma nominal monstrum e a verbal monstrare tendem à diferenciação de significado, guardando o primeiro termo a designação de coisa que sai do ordinário, algo medonho, que viola de maneira repulsiva a ordem natural das coisas. Já o segundo termo vai designar simplesmente a ação de mostrar, apresentar sem qualquer referência ao elemento terrificante.

A evolução desse conceito desde a Antiguidade, passando pelo Renascimento até o século XIX, época da teratologia, sua relação com o Iluminismo e as grandes metamorfoses sociais, como a Revolução Francesa e a revolução industrial, bem como seu papel na narrativa literária do século dezenove, são de grande importância para a compreensão da complexidade e riqueza de significados que envolvem este termo. Para Mary Del Priore, historiadora brasileira:

A palavra monstro é ambígua, pois recobre realidades diferentes: na Idade Média, ela evoca a ideia de diferença, de estranhamento, mas também de emanação do poder do Criador. Durante o Renascimento, a de maravilha e prodígio e, igualmente, a de força maléfica e abismo devorador. Durante o século XVII, ela se reveste de credulidade científica, envolvendo, contudo, as armadilhas da razão. (...) Duzentos anos de literatura nos revelam as rupturas e permanências das ideias, das mentalidades e dos comportamentos em face dos monstros. Há nessa trajetória uma quase universalidade de imaginação sobre os monstros em todas as sociedades, do passado e do presente. O que leva a pensar que eles têm, aí, um papel importante; 
os homens, todos eles, obrigam-se a construir mentalmente algo que lhes dê medo. E esse medo pode ter suas fontes na religião, na ciência ou na política. (PRIORE, 2000: 34)

\subsubsection{Debates acerca da credibilidade}

Discursos científicos, teológicos e estéticos, nos registros eruditos e populares, variavam e se reinventavam, influenciando-se mutuamente. No plano da medicina, relatos e ilustrações eram, com frequência, ferramentas únicas na constituição da verossimilhança de muitas das ocorrências monstruosas, dada sua raridade. Nesse caso, a ciência encontrou suas fontes e seus limites no imaginário e na cultura popular (COSTA, 2005: 9). Paralelamente, no caso dos cordéis portugueses do século XVIII, era comum o apelo à cientificidade para atribuir credibilidade ao tratamento de seres fantásticos.

A insistência em marcas de referencialidade, bem ao gosto, por exemplo, dos canards franceses, como são a opção pelo discurso em primeira pessoa, a utilização da estrutura da carta, a apresentação de testemunhas e de fatos tão concretos e localizáveis quanto possível, com introdução de pormenores e, até, de alguma aproximação aos assuntos de teor cientificista, também funciona como elemento caracterizador de um gênero de textos que conheceu grande sucesso em diferentes países ao longo de vários séculos. As imagens dos monstros, a par dos títulos claramente codificados do ponto de vista retórico-estilístico, funcionariam como elementos de índole paratextual indicadores do gênero, desempenhando igualmente importante função comercial na divulgação e publicitação dos folhetos junto dos eventuais compradores (RAMOS, 2005: 446).

Veremos à frente que relações semelhantes podem ser observadas na amostragem de folhetos brasileiros selecionados para esta pesquisa e que mesmo a referência aos canards franceses pode ser aproximada, com ressalvas, a paralelos entre esses folhetos e jornais populares da época. Retomando o cenário europeu, observamos trânsitos entre conhecimentos de diferentes níveis de prestígio a respeito de seres fantásticos na Idade Média que chegam a surpreender:

Some Christian writers, especially those most influenced by Augustine, saw skepticism concerning wonders as the hall-mark of the narrow-minded and 
suspicious peasant, trapped in the bubble of his limited experience, while belief characterized the pious, the learned, and the theologically informed (DASTON \& PARK, 1998: 62).

Apesar desses pressupostos culturais em favor da crença, leitores e escritores sabiam que os relatos de maravilhas poderiam ser falsificados ou enganosos. Dados precisos, como data e local das aparições, eram de fundamental importância no processo de construção da verossimilhança a respeito dos prodígios. A produção de imagens e a apresentação de testemunhas tinham grande importância, como afirmam Lorraine Daston e Katharine Park (DASTON \& PARK, 1998:65-66).

A exploração de espaços recém-descobertos pelos europeus alimentou um rico imaginário referente a seres extraordinários. Tratando da aventura rumo ao desconhecido, Afonso d'Escragnolle Taunay (1876-1958) apresenta em Monstros e monstrengos do Brasil uma compilação da "fauna fantástica brasileira". Sua fonte é a literatura que se escreveu sobre o Brasil desde o descobrimento, incluindo clássicos como os Diálogos das grandezas do Brasil, e outros documentos que evidenciavam um imaginário maravilhoso em torno das criaturas exóticas que habitavam o território. $\mathrm{O}$ apanhado de relatos trata dos mais curiosos animais às mais assustadoras feras: uma espécie de gambá cujo fedor deixa um homem ou um cavalo desacordado durante várias horas, javalis que respiram por um buraco no dorso, porcos monteses que têm o umbigo nas costas e que cometem suicídio coletivo, uma espécie de peixe que tem pedras no lugar dos miolos, lagartos que se alimentam de vento, ou envenenam as frutas ao tocá-las, um tipo de onça marinha que é metade jaguar e metade peixe, entre outros. 


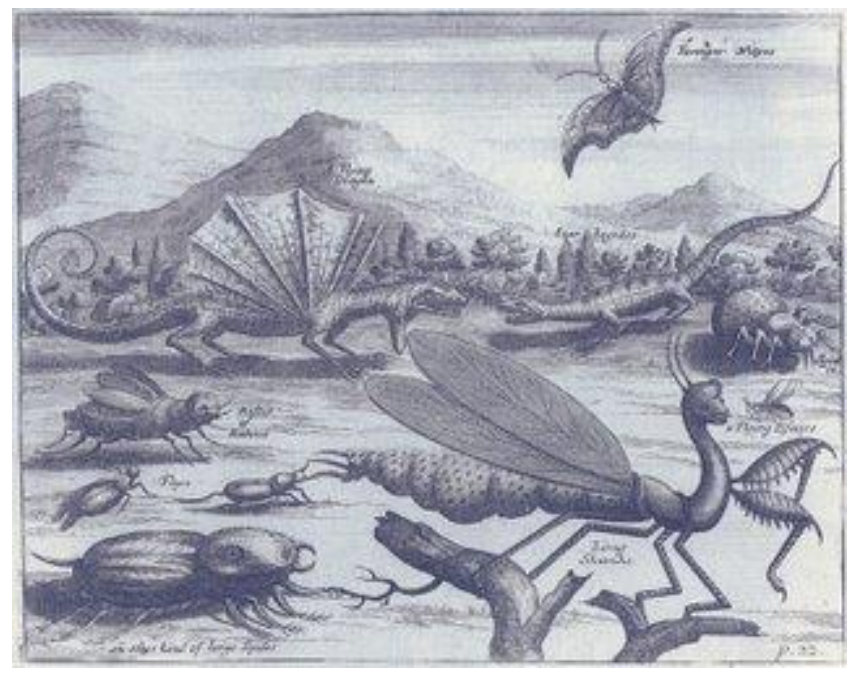

Figura 3a Fauna do Brasil em meados do século XVIII, segundo Nielhoff. (Fonte: TAUNAY, Visconde de (Afonso D'escragnolle Taunay). PRIORE, Mary Del (Org.). Monstros e monstrengos do Brasil. São Paulo: Companhia das Letras, 2011)

Do ponto de vista político, monstros estrangeiros - tais como "o portentoso monstro, que da província da Anatólia foi enviado ao Sultão dos Turcos" (CESARINY, 2004:329) -, contribuíam para a construção da imagem de territórios inimigos repletos de curiosas criaturas que estariam sendo escondidas especialmente pelos distantes povos orientais e não cristãos. 


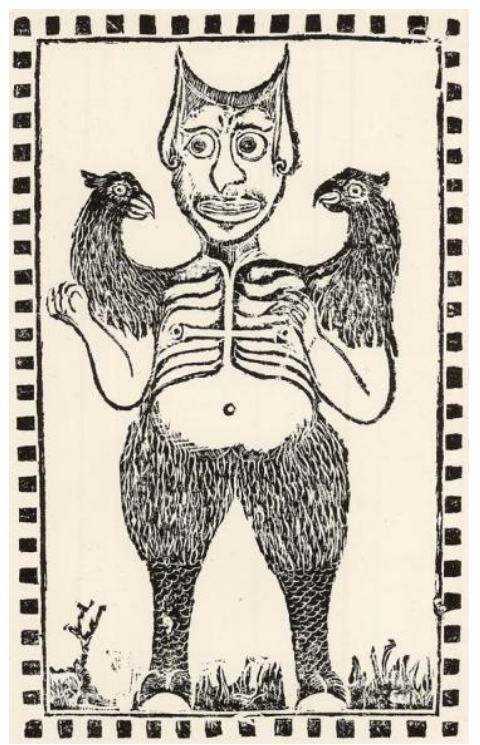

Figura 4 a Emblema vivente, ou notícia de hum portentoso monstro, que da Província de Anatólia foy mandado ao Sultão dos Turcos. Com a sua figura, copiada do retrato, que delle mandou fazer o Biglerbey de Amafia, recebida de Alepo, em huma carta escrita pelo mesmo. (Fonte: CESARINY, Mario. Horta de literatura de cordel. Lisboa: Assírio \& Alvim, 2004)

Mary Del Priore aborda a atualidade destes seres numa contemporaneidade em que a própria humanidade se caracteriza pela fragmentação:

Abandonados por Deus, mas normalmente presentes, pois a humanidade nunca deixou de amar os monstros. (...) A grande imprensa, o cinema, a televisão, a publicidade, as histórias em quadrinhos, mecanismos elaboradores de novas formas de conhecimento, deram espaço a monstros, industrializando imagens e sonhos fantásticos. (...) Numa era que se caracteriza pela ciência e pela tecnologia, é impressionante constatar o fascínio pelos símbolos e motivos monstruosos, que trazem de volta a noção de um universo encantado e fantástico. Mais um dos fenômenos sintomáticos da profunda crise que se instalou no pensamento, o interesse por monstros revela quanto nossa venerada crença no racionalismo e no mecanicismo, bem como na visão de progresso inevitável, está fragmentada (PRIORE, 2000: 12). 


\subsubsection{O grotesco: riso e medo}

Para cada virtude e para cada pecado há um exemplo tirado dos bestiários, e os animais tornam-se figuras do mundo humano (Umberto Eco, 1989: 87).

A origem da palavra é italiana: grottesco. Quando, no século XIV, os italianos começaram a escavar os alicerces dos prédios mais antigos de Roma, encontraram muitas grutas. As pinturas deixadas em suas paredes foram chamadas de grotescas. Exóticas, até ridículas. A palavra passou a designar peças que fogem ao padrão convencional.

O caráter enigmático e secreto do impacto do grotesco parece ter sido associado ao caráter subterrâneo e secreto da sua origem - ruínas soterradas e catacumbas. A palavra não deve ser derivada de grotta no sentido literal, mas de oculto e cavernoso - significações contidas nas palavras caverna e grota (BENJAMIN, 1984: 193).

A dificuldade entre os críticos para formulação de um conceito homogêneo que compreendesse todas as manifestações do grotesco como categoria deveu-se à polissemia imanente ao vocábulo "grotesco". Kayser localiza-o nas zonas do fantástico e do sinistro.

Do "abismo" surgem os animais do apocalipse, demônios irrompem na vida cotidiana. Tão logo pudéssemos nomear os poderes e assinalarmos algo na ordem cósmica, o grotesco perderia algo de sua essência (...) O que irrompe permanece inconcebível, impessoal. Poderíamos usar uma nova expressão: o grotesco é a representação do "id", esse id "fantasmal", que, segundo Ammann, constitui a terceira significação do impessoal. (KAYSER, 2003: 159)

Para o autor, define-se como grotesco uma estética do sobrenatural, do bizarro, do monstruoso, mas também do ridículo, oposta ao sublime. Ele a percebe como algo perturbador da ordem natural das coisas, que desestrutura e assusta, transmutando o mundo e sua ordenação:

O mundo do grotesco é o nosso mundo - e não é. O horror mescla-se ao sorriso e tem seu fundamento justamente na experiência de que nosso mundo confiável, aparentemente arrimado numa ordem bem firme, se alheia sob a irrupção de poderes abismais, se desarticula nas juntas e nas formas e dissolve em suas 
Variando de acordo com os valores estéticos de período histórico para período, de artista para artista, e mesmo no âmbito da fruição estética de espectadores particulares, o grotesco mostra-se como uma categoria mutável; portanto, seu conceito é um terreno movediço para os que buscam uma sentença universal para a definição do que ele seja (SANTOS, 2009:5). As teorias tendem a concordar que são constitutivos do grotesco elementos como: o hibridismo entre contrários, as metamorfoses abruptas, a loucura, o universo onírico, o absurdo, o riso mesclado ao terror, a intervenção do sobrenatural no cotidiano, e demais recursos que visam expressar a obra de arte por meio da surpresa com o fim de provocar, especialmente, o estranhamento (SANTOS, 2009:6).

Já Mikhail Bakhtin, em seu estudo dos elementos oriundos da cultura popular presentes na obra do citado Rabelais, vale-se de uma tipologia do grotesco que atribui suas raízes aos costumes do vulgo, os quais precederiam, cronologicamente, as feições que o grotesco assume no romantismo, foco da análise de Kayser. Bakhtin localiza o grotesco mais no campo da comicidade, menos atrelado ao horror, sendo comum a construção de imagens que tematizem de forma mais leve a hibridização: corpos incompletos, misturados ao mundo, fundidos a animais e a coisas. Para o autor, o grotesco traz em si aspectos libertadores:

O riso e a visão carnavalesca do mundo, que estão na base do grotesco, destroem a seriedade unilateral e as pretensões de significado incondicional e intemporal e liberam a consciência e a imaginação humana, que ficam assim disponíveis para o desenvolvimento de novas possibilidades (BAKHTIN, 1993:43).

O carnaval é para Bakhtin um evento de libertação do homem medieval, oferecendolhe um segundo mundo e uma segunda vida, onde todos são iguais e reina uma espécie de contato livre, diferente da realidade oficial, imposta pelas estruturas feudo-clericais, onde o riso é livre. O princípio do riso se encontra na base de todas as imagens das festas populares:

O riso tem um profundo valor de concepção de mundo, é uma das formas capitais pelas quais se exprime a verdade sobre o mundo na sua totalidade, sobre a história, 
sobre o homem; é um ponto de vista particular e universal sobre o mundo, que percebe de forma diferente, embora não menos importante (talvez mais) do que o sério; por isso a grande literatura (que coloca, por outro lado, problemas universais) deve admiti-lo da mesma forma que ao sério: somente o riso, com efeito, pode ter acesso a certos aspectos extremamente importantes do mundo. (BAKHTIN, 1999:61-62).

Ao analisar a cultura cômica popular da idade média e do renascimento, Bakhtin demonstra a complexidade e riqueza das fontes populares de Rabelais. A riquíssima cultura popular do riso na Idade Média viveu e se desenvolveu fora da esfera oficial da ideologia e da literatura elevada. E foi graças a essa existência extra-oficial que a cultura do riso se distinguiu por seu radicalismo e sua liberdade excepcionais, por sua implacável lucidez.

De fato, logo na epígrafe aos leitores do Gargantua encontramos:

"Não pronunciar palavras vãs ou ridículas; e não amar o riso excessivo ou desmedido. Regra de São Benedito (séc. V-VI)”

A interdição do riso já é rompida e radicalizada no decorrer de Gargantua e Pantagruel. Gargantua é um personagem emblemático da Idade Média, fruto da alegria proporcionada pelo grotesco encontro de Grandgousier com Gargamelle. Os dois costumavam brincar de "bicho de duas costas", esfregando-se alegremente, quando ela ficou grávida de um lindo filho, que carregou consigo durante onze meses. É, portanto, filho de "um folgazão" com rapariga bonita e cara (RABELAIS, 1986, p. 55). Habita um mundo de transgressões na qual o homem e o animal se igualam no primado do instinto, estabelecendo, ainda que provisoriamente, a negação da ordem racional: "Comia na mesma tigela que os cachorrinhos do pai. Mordia-lhes as orelhas e eles lhe arranhavam o nariz; soprava-lhes o cu e eles lambiam-lhe as bochechas" (RABELAIS, 1986, p. 86). Considera a bebedeira e a comilança não como vícios, mas como formas de fugir aos contratempos da vida. "Feliz não é quem cedo se levanta, mas quem cedo bebendo, o mal espanta” (RABELAIS, 1986, p. 125). Ou, então: "Anunciemos, ao som das botijas e garrafas que quem tiver perdido a sede não tem nada a fazer aqui" (RABELAIS, 1986, p. 63). E ainda: "Beba sempre que não morrerá" (RABELAIS, 1986, p. 61). Prega um distanciamento necessário da vida séria e regrada para que se possa ter uma conversa repassada de conclusões filosóficas, que traduzem experiências práticas na confraria desses bebedores. 
A epígrafe é representativa da posição da cultura letrada medieval em relação ao riso, que encontra sua expressão mais articulada nos comentários a Aristóteles. Este apoiou sua visão do cômico como triunfo do amor próprio: o riso nos torna superiores àquele que nos faz rir. São Tomás de Aquino teria defendido que "o humor, faz parte da natureza humana, seguindo na esteira do pensamento aristotélico segundo o qual o riso é próprio do homem (...) a 'laetitia', o deleite espiritual era um bem reservado aos eleitos à salvação eterna" (MACEDO, 2000:70).

$\mathrm{Na}$ alta Idade Média seres maravilhosos eram uma realidade, de certa forma, distante para escritores e leitores europeus. Com a ausência de redes regulares de comunicação e comércio, romances e livros sobre viagens ofereciam prazer e entretenimento, permitindo que seus leitores pudessem fantasiar a respeito de realidades alternativas estranhas ou fabulosas. Futuramente leitores e escritores passaram a ter interesse por uma abordagem mais complexa do tema, o que suscitou debates a respeito de crença e credibilidade, assim como em torno da recepção e verossimilhança. Como seus antecessores da antiguidade clássica, a maioria dos enciclopedistas medievais e cosmógrafos viam-se, em primeira instância como filólogos, engajados na recolha e transmissão de testemunhos, sem avaliar constantemente sua verdade ou plausibilidade. O mundo medieval Cristão, ainda mais do que o de escritores antigos, era um mundo de maravilhas. O cristianismo adicionou uma dimensão temporal para os fenômenos, trazendo-os para o presente, enfatizou súbitas erupções do maravilhoso no curso da vida cotidiana sob a forma de milagres, prodígios, e outras formas de comunicação divina. Assim, se fizeram mito e maravilha, não mais confinados a uma terra distante ou a um descontínuo passado, como se fazia na antiguidade. Os dogmas da providência divina, mais antigo critério de confiança e plausibilidade, trataram com desprezo, mas não diminuíram, no entanto, o impacto dos relatos particulares da experiência comum. Alguns escritores cristãos viam o ceticismo quanto às maravilhas como a marca do camponês tacanho e suspeito, preso na bolha de sua experiência limitada, enquanto a crença caracterizou o piedoso, o aprendido, e o teologicamente informado.

Apesar destes pressupostos culturais em favor da crença, leitores e escritores sabiam claramente que os relatos de maravilhas poderiam ser falsificados ou enganosos. Dados precisos, como data e local das aparições eram de fundamental importância no processo de construção de verossimilhança a respeito dos prodígios. A produção de imagens e a 
apresentação de testemunhas tinham grande importância, conforme vemos nesta descrição registrada por um anônimo em Paris, no século XV:

Item, on June 6, 1429, two children were born at Aubervilliers who were exactly as you see in this image, for I myself truly [pour vray] saw them and held them in my hands: they had as you see two heads, four arms, two necks, four legs, four feet, but only one belly and one navel; two heads, two backs. They were christened, and were kept above ground for three days so that the people of Paris could see this great wonder. And truly [pour vray] more than ten thousand people, men and women, went from Paris to see them. They were born at around seven in the morning and christened in the parish of Saint- Cristophe, and the one on the right was named Agnes and the one on the left Jehanne. Their father was Jean Discret and their mother Gillette, and they lived about an hour after baptism. (DASTON \& PARK, 1998:65)

Apesar de seus temores, os europeus ansiavam por contato direto com os fenômenos raros em todas as suas múltiplas formas. Querendo se tornar testemunhas, eles formaram grupos para ver os gêmeos de Aubervilliers. Espécies exóticas eram vistas com o mesmo fascínio e trazidas por mercadores que as comercializavam junto a artigos relacionados, dotados ou não de veracidade, compondo uma cultura social e material do maravilhoso em complemento à tradição textual (DASTON \& PARK: 1998, p.60). 


\subsubsection{Entre culturas próximas e distantes}

O pavão de asas abertas

Partiu com velocidade

Coroando todo o espaço

Muito acima da cidade

Como era meia noite

Voaram mesmo à vontade.

Então disse o engenheiro:

- Já provei minha invenção

fizemos a experiência

tome conta do pavão

agora o senhor me paga

sem promover discussão.

(MELQUÍADES, [s.d])

O Romance do Pavão Misterioso, um dos maiores clássicos do cordel brasileiro, narra a aventura de um rapaz, chamado Evangelista, jovem turco, que ao contemplar a beleza de Creuza, donzela grega, conservada prisioneira pelo seu pai, sente-se invadido por um forte desejo: tirar a moça do sobrado do conde e tomá-la como mulher. Evangelista foge com Creuza utilizando um curioso "pavão mecânico". A história é povoada de perigos e ameaças, o herói reveste-se de uma atmosfera próxima a de criaturas míticas, habitantes de um espaço e de um tempo distantes. Nesta obra encontramos ressonâncias das "Mil e Uma Noites" e de grandes clássicos ocidentais, como a Ilíada. É relevante observarmos que não é possível dizer ao certo qual teria sido o contato do poeta com essas obras, mas podemos notar marcas da circularidade que, neste caso, teria imprimido na literatura "popular" marcas do cânone literário, e, vale ressaltar que o cordel, relido por diversos autores marcou uma série de produções da contemporaneidade, especialmente na música, como na canção de Edinardo em 1972, regravada anos depois pelo cantor Ney Mato Grosso e em obras voltadas para o público jovem e muitas vezes utilizadas como material paradidático, a exemplo da adaptação homônima lançada em 2004 pela editora Cosac Naify.

Qualificado como misterioso, o pavão é uma figura de significados mágicos. Aparece como montaria em algumas mitologias e na tradição cristã é sinal de imortalidade. O cordel em questão ainda trata da relação entre o universo fantástico e o científico na medida em que a tecnologia da máquina complexa, criada em um reino distante, estre os povos que a 
desconheciam, só poderia ser concebida como exuberância da própria natureza, capaz de façanhas incríveis, como voos inimagináveis para aves comuns.

Seres monstruosos, fantásticos ou zoomórficos habitaram a mitologia e a religiosidade das mais distantes civilizações. A própria Ilíada, mencionada no caso do Pavão Misterioso, revela muito sobre a antiga religiosidade grega, marcada por deuses fantásticos e criaturas mitológicas híbridas como o centauro, ou as sirenes. Seriam incontáveis tais referências se levássemos em consideração um sem número de civilizações, tribos e agrupamentos diversos para os quais a cultura ocidental dedicou pouca atenção. Veremos à frente que certos motivos se repetem no tempo e no espaço, nas tradições de prestígio e nas de desprestígio.

\subsubsection{Tradições explicativas acerca de seres monstruosos}

Criaturas fantásticas foram entendidas das mais diversas formas na cultura ocidental de séculos atrás. Palmira Fontes da Costa, em sua obra sobre o corpo insólito e o tratamento dado a aparições monstruosas no Portugal do século XVIII, recorre a Jean Céard para demonstrar uma possível sistematização destes entendimentos. O estudioso identificava três principais correntes teóricas acerca do corpo monstruoso no universo europeu: a tradição médico-científica, marcada inicialmente pelo pensamento aristotélico; a concepção do ser monstruoso como maravilha da natureza, proposta por Santo Agostinho; e, finalmente, o tratamento do monstruoso como presságio de castigos divinos, conforme definição de Cícero (COSTA, 2005:3-4).

Kappler propõe, com base em registros de variadas origens na Europa da era medieval, a divisão do fantástico entre "fenômenos prodigiosos" e "manifestações das forças naturais" Vulcões, terremotos e fenômenos aquáticos, manifestações excepcionais dos elementos da natureza poderiam se traduzir em produções prodigiosas. Fenômenos que interrompem o ciclo da natureza, tais como eclipses, ou fenômenos acústicos também resultariam em alguma espécie de tradução material. Para ele, os fenômenos prodigiosos de maior afinidade com a monstruosidade, no entanto, são as metamorfoses: todo indivíduo metamorfoseado de alguma maneira se torna um monstro para seus ex-pares e, supostamente, 
tais transformações estariam associadas à ação do demônio (KAPPLER, 1994:242-250).

De volta às possíveis "tradições explicativas" acerca de monstros, e com vistas a não estender demasiadamente o assunto, sugerimos uma divisão em dois grandes grupos: criaturas como seres exteriores à natureza (isto é, ligados a uma intervenção direta de Deus, ou das mais diversas divindades), portanto sobrenaturais ou, como simples desvios de um "curso ordinário" do mundo, portanto, naturais. Desde já, não tenhamos a ingenuidade de localizar as tradições do primeiro tipo como características do "povo", ou de épocas "pouco esclarecidas", opostas às explicações, por assim dizer, naturalistas, que se localizariam no domínio da "ciência moderna". Na verdade, essas tradições jamais se excluem mutuamente, pois podem conviver em uma mesma época ou até em um mesmo autor. A conceitualização de monstros como presságios (teromancia), castigos, ou ainda como signos do poder ilimitado de Deus, por exemplo, não são exclusividade da Antiguidade Clássica ou da Idade Média, pois permanece atuante, ao menos até o século XVII, e não apenas nos registros “populares" - Ambroise Paré sintetiza um pouco disto, pois reconhece essa dimensão "sobrenatural", ao mesmo tempo em que tenta oferecer uma teoria médica, uma teratologia naturalista. Talvez o que esteja em jogo aqui seja justamente a mudança de limites entre "natural" e "sobrenatural", ou melhor, as disputas sobre o que seria o curso ordinário da natureza (que, para alguns, seria interrompido pelos monstros), o que indicaria a operação de uma "causa externa", sobrenatural, enquanto que outros consideram a monstruosidade apenas rara, mas explicável a partir do mesmo quadro conceitual operante na descrição de qualquer outro fenômeno.

Assim, a ideia de monstros como prodígios ou maravilhas, vindos de uma intervenção direta de Deus, não é característica de uma população "crédula" ou "supersticiosa", em contraste com outra pretensamente mais "científica", que buscaria apenas causas naturais para sua existência. As obras de história natural e de filosofia dos séculos XVI e XVII testemunham como os "cientistas" estão frequentemente perto do sobrenatural quando falam dos monstros. Locke e Leibniz (DASTON; PARK, 1998: 239-240), por exemplo, partem de uma metafísica que vem de Aristóteles, segundo a qual as coisas deveriam poder ser agrupadas por suas essências, formando "tipos naturais". A essência estaria nos objetos, e não nos sujeitos de conhecimento. O problema é que existem coisas que parecem pertencer a mais de um grupo: por exemplo, pedras são pedras, metais são metais, mas um ímã, em 
essência, é pedra ou é metal? Um morcego é mamífero porque mama, mas é um pássaro porque voa? (ARISTÓTELES, 2005.)

Os relatos acerca de maravilhas e prodígios problematizam ainda mais esses agrupamentos o que fazer com criaturas que desafiam as classificações, como os monstros, em cuja existência eles acreditam piamente? Locke opta por uma explicação naturalista, Leibniz para Deus e ambos criticam o esquema classificatório aristotélico (cf. LOOK, 2009).

Somente no século XVIII se consolidou uma opção clara pelas explicações naturalistas (elas próprias muito variadas) nos registros "eruditos", talvez por duas razões: uma crescente diferenciação entre "natural" e "sobrenatural" nas explicações científicas e um deslocamento parcial do conceito de "maravilhoso" em parte para o de "exótico", e em parte para o de "sublime".

Explicações naturalistas e sobrenaturais são frequentemente misturadas no âmbito jurídico. Tanto o direito civil europeu quanto o eclesiástico precisaram confrontar com frequência os monstros: o que fazer com um deformado? Ele pode se tornar sacerdote (aqui a resposta é sempre não)? Pode tomar a comunhão? É responsável por seus atos? Pode participar de contratos, ser dono de alguma coisa, ou é considerado permanentemente incapaz? Mas então alguém é responsável por ele, ou mesmo seu proprietário? É fácil pressentir que as respostas a essas perguntas envolvem ponderações complicadas entre o poder de Deus, que quis criar um corpo abjeto, e os direitos naturais desse corpo (cf. FADINI; NEGRI, WOLFE, 2001).

Finalmente, nas inúmeras práticas que os fazem objetos de prazer se observa o difícil estatuto dos monstros. Os circos do século XIX, com mulheres barbadas, anões, gigantes e siameses logo vêm à lembrança, mas essas pessoas já tinham papéis semelhantes na cultura de diversas cortes europeias pelo menos desde o século XV. Nas cortes eram, muitas vezes, as únicas pessoas com autorização para falar o que quisessem para os próprios monarcas, em parte por conta da proteção oferecida pela associação suposta entre deformidade física e incapacidade mental, mas em parte também por suas associações sobrenaturais (cf. BOUZA, 1991).

Algumas dessas questões tangenciam o tratamento do ser monstruoso nos folhetos 
de cordel brasileiros, questionando a existência de muros entre diferentes esferas do saber e mesmo a pretensa uniformidade que cristaliza teorias de prestígio. Assim, seguimos para o capítulo 2 no espírito do aprofundamento dos debates dobre cultura. 


\section{Capítulo 2}

\subsection{Culturas populares, cordéis e seus monstros}

\subsubsection{Reflexões sobre culturas}

Ao refletir sobre a representação do fantástico e do monstruoso em registros que transitam entre os mais variados níveis de prestígio, faz-se premente uma discussão acerca da expressão e da própria ideia de "cultura popular". A começar pelo vocábulo "cultura", temos, do latim, colere (cultivar ou instruir) e cultus (cultivo, instrução). A palavra surge associada ao ambiente agrário e ao trabalho com a terra, uso ainda vigente. A palavra associou-se também à ideia de "cultura letrada". Cultura é hoje um termo vasto e complexo que ainda alimenta o dissenso entre estudiosos de diversas áreas.

Já “cultura popular” é considerada por muitos somente como uma categoria erudita, alegando-se que pretende somente relembrar os debates em torno da própria definiçãa, travados a propósito de um conceito que quer delimitar, caracterizar e nomear práticas raramente designadas pelos seus atores como pertencendo à “cultura popular". Neste ponto torna-se inevitável questionar se há de fato uma cultura erudita separada de uma cultura popular como compartimentos estanques. A separação desses dois polos foi uma invenção dos intelectuais europeus, na segunda metade do século XVIII. Por meio do conceito de folclore ("saber do povo"), eles demarcaram a fronteira das manifestações culturais das camadas sociais abastadas em relação àquelas mais amplamente difundidas.

No século XIX, o povo, especialmente a população rural, foi idealizado, com sua produção cultural tendo sido retratada como "pura", "natural" e "resíduo" do passado. Essa idealização desencadeou o início de muitas pesquisas folclóricas que se empenharam em descobrir uma cultura "primitiva”. Segundo essas pesquisas, as manifestações folclóricas, herdadas do mundo rural, estavam condenadas à morte, devido ao seu crescente contato com influências "deletérias" dos centros urbanos (CERTEAU; JULIA; REVEL, 1989: 63). Entretanto, ao longo do século XX, após uma série de estudos que se debruçou sobre as 
manifestações populares "sobreviventes", essa concepção foi se tornando cada vez mais insustentável. Batizou-se, então, a categoria "cultura popular" no lugar da restritiva "folclore".

\subsubsection{Pressupostos teóricos}

Em seu artigo polêmico “A beleza do morto: o conceito de cultura popular”, Michel de Certeau, Dominique Julia e Jacques Revel declaram que a cultura popular pressupõe uma operação difícil de reconhecer. Centrados, sobretudo, na experiência dos estudos consagrados aos colportage (folhetos conhecidos aqui como literatura de cordel), os autores observam como as elites francesas do século XIX procuraram censurar e patrulhar, por meio da concessão de licenças, o conteúdo desses impressos. Vistos como contrários à ordem, à moral e à religião, os colportages foram perseguidos, retirados de circulação e condenados ao perecimento. Não obstante, tal medida repressiva deu origem à curiosidade científica. As elites intelectuais se interessaram em "salvar" os colportages. Embalsamaram-nos como coisa inofensiva, exótica e em extinção. Na contramão das explicações então correntes, os historiadores franceses argumentaram que a cultura popular resultou de uma fabricação deliberada das elites: concordava-se em exaltar a inocência e a importância da cultura popular quanto mais se mobilizava para acelerar sua morte. Os autores falavam da "beleza do morto" para se referirem à atitude das elites de só atribuírem valor às manifestações da cultura popular quando estas não representam mais perigo, ou seja, estão mortas. A cultura popular, por essa perspectiva, significa uma "sombra", um "fantasma" e um "enigma da Esfinge". Não é de estranhar "que este objeto assuma a imagem de uma origem perdida: a ficção de uma realidade a encontrar mantém a marca da ação política que a organizou" (CERTEAU; JULIA; REVEL, 1989: 63). Assim, “onde estamos, senão no seio da cultura erudita? Ou: a cultura popular existirá fora do ato que a suprime?" (CERTEAU; JULIA; REVEL, 1989: 74).

Alertando para o fato de que a cultura popular é difícil de ser definida devido à polissemia dos termos que a compõem, "cultura" e "popular", o sociólogo Denys Cuche a analisa como uma cultura que se constrói e reconstrói numa situação de dominação. Mesmo sendo dominada, é uma "cultura inteira", baseada em valores originais que dão sentido à sua 
existência, construindo-se na história das relações entre os grupos sociais e na relação, recorrentemente conflituosa, tensa e violenta, com outras culturas. Se numa sociedade existe uma hierarquia social, uma diferenciação social e hierárquica também se refletirá na cultura, ou seja, para o autor as culturas populares são culturas de grupos sociais subalternos ${ }^{3}$. Para Cuche, afirmar que a cultura popular é uma cultura dominada não significa dizer que ela é alienada, ou subjugada o tempo todo, é, antes, admitir que assim está em relação a outras culturas, notadamente, a cultura dominante:

As culturas populares revelam-se, na análise, nem inteiramente dependentes, nem inteiramente autônomas, nem pura imitação, nem pura criação. Por isso, elas confirmam que toda cultura particular é uma reunião de elementos originais e importados, de invenções próprias e de empréstimos. (CUCHE, 1999: 149).

As ideias de Cuche são importantes, especialmente quando se considera as relações, na maioria das vezes, tensas e conflituosas, entre as culturas, ou seja, a partilha de signos e significados, e ao enfatizar a contestação e a provocação como intrínsecas à cultura popular. Procurar-se-á refletir brevemente nestas páginas sobre o que há para além deste conflito.

Anterior a Cuche, o historiador E. P. Thompson produziu estudos interdisciplinares em que a perspectiva teórica e o desenvolvimento do conceito de classe social revelam-se permeados por embates e complementaridades entre a esfera cultural e econômica, entre o plano simbólico e estrutural, e relacionou certo espírito provocatório à cultura popular. Em A formação da classe operária inglesa, acrescentou o exame do mundo cultural dos trabalhadores. O livro conta com um apanhado das principais ideias do autor, incluindo seus problemas de pesquisa, hipóteses formuladas e fontes por ele utilizadas e interpretadas. Segundo ele, a cultura coloca-se, antes de tudo, como prática social originada da experiência compartilhada. Ao realizar sua pesquisa, somou a dimensão cultural ao materialismo histórico. Seu interesse pela problemática cultural não se encerrou aí. Em seus trabalhos posteriores, passou a pesquisar rituais, vendas de esposas, rough music, motins da fome, enfim os costumes dos populares ingleses do século XVIII. Nestes estudos, Thompson examina a tradição popular, a cultura e a sociedade na perspectiva da chamada história vista

\footnotetext{
${ }^{3}$ Derivado de uma concepção gramsciana, o termo subalterno trata das relações de dominação sintetizando um dos principais focos de interesse dos Estudos Culturais, não apenas nos seus primórdios, como também na sua configuração atual.
} 
de baixo. Para tal, recorreu a documentos pouco usuais e considerados ilegítimos por parte dos historiadores da época. Entre as fontes utilizadas estão memórias de indivíduos; matérias de jornais da época como o Tribune e o Morning Post, além de relatos de manifestações e agitações de rua; discursos de políticos e cartas entre estes; diários de diferentes pessoas; registros de inquéritos, depoimentos e fichamentos policiais; panfletos da época, de cunho religioso e político; literatura do período; correspondências entre indivíduos das Sociedades de trabalhadores; atas de julgamentos; e relatórios das atividades das Sociedades, produzidas por estas ou pelas autoridades através de espiões.

Em Costumes em comum, Thompson atrela a cultura à ideia dos costumes populares e afirma que "a cultura popular é rebelde, mas o é em defesa dos costumes" (2010:19), e critica uma espécie de visão paternalista da sociedade, que oculta as formas de exploração do trabalhador de modo que passam a ser sutilmente impostas de maneira consentida.

Assim como Thompson, Raymond Williams foi um ex-militante do PC inglês, desacreditado do marxismo tradicional e engajado na educação popular para adultos. Sua obra teve importância fundamental à formação dos Estudos Culturais. Em Cultura $e$ Sociedade, o autor elaborou um conceito de cultura ligado à experiência dos sujeitos:

\footnotetext{
A história da ideia de cultura é a história do modo por que reagimos em pensamento e em sentimento à mudança de condições por que passou a nossa vida. Chamamos cultura a nossa resposta aos acontecimentos que viemos a definir como indústria e democracia e que determinam a mudança das condições humanas. Essas condições foram criadas pelos homens e por eles modificadas. (WILLIAMS, 1969: 305)
}

Além disso, nesta mesma obra, Williams problematizou a noção de uma cultura da classe trabalhadora:

A cultura que (a classe trabalhadora, por motivo de sua posição) produziu e que é importante assinalar é a instituição democrática coletiva, seja nos sindicatos, no movimento cooperativo ou no partido político. A cultura da classe trabalhadora, nos estágios através dos quais vem passando, é antes social (...) que individual (...). Considerada no contexto da sociedade, essa cultura representa uma realização criadora notável. (WILLIAMS, 1969: 335)

Williams, que se identificava com o pensamento de tradição marxista, designou sua 
posição como "materialismo cultural”. Através de um olhar diferenciado sobre a história literária, ele mostra que cultura é uma categoria-chave que conecta a análise literária com a investigação social.

Tanto para Williams quanto para Thompson, cultura era uma rede vívida de práticas e relações que constituíam a vida cotidiana, dentro da qual o papel do indivíduo merecia atenção. Mas, de certa forma, Thompson resistia ao entendimento de cultura enquanto uma forma de vida global. Em vez disso, preferia entendê-la enquanto um enfrentamento entre modos de vida diferentes. Vale discorrer acerca da importância dos Estudos Culturais para esta pesquisa, pois no momento em que prestam atenção às formas de expressão cultural não tradicionais, modifica-se a ideia de legitimidade cultural. Assim, a cultura popular alcança legitimidade, transformando-se em espaço de atividade crítica e de intervenção. Dessa forma, a consideração sobre a pertinência de analisar práticas que tinham sido vistas fora da esfera da cultura inspirou a geração que desenvolveu os adeptos a estes estudos, principalmente a partir dos anos 1960. Os Estudos Culturais constituíram uma tendência importante da crítica cultural que questiona o estabelecimento de hierarquias entre formas e práticas culturais determinadas a partir de oposições como cultura alta/baixa, superior/inferior. Embora os Estudos Culturais tenham se pautado em discussões contrárias aos binarismos e à guerra contra os cânones, fronteiras disciplinares e muros acadêmicos, não se caracterizam por uma única teoria ou metodologia unificada.

No campo da história cultural importantes discussões são travadas a respeito das relações culturais nas sociedades. Neste grupo, também diversificado, não há exatamente uma unidade teórica ou metodológica. São associados à história cultural nomes como Burke, Darnton, Ginzburg, Chartier e Davis. Este campo de estudo, assim como os Estudos Culturais, gerou críticas por parte dos historiadores marxistas de base economicista: para eles, os chamados "culturalistas" colocavam a cultura em posição de superestrutura entendendo que esta atuaria como determinante da infraestrutura, baseados demasiadamente em impressões e não nas determinações impostas pelos modos de produção.

Peter Burke procurou problematizar algumas destas questões e mesmo admitir algumas das fragilidades do campo de estudo em $O$ que é história cultural?. Também em seu Cultura Popular na Idade Moderna Burke discute a ideia de "descoberta do povo" e 
questiona:

De quem é a cultura popular? Quem é povo? (...) A dificuldade em se definir o "povo" sugere que a cultura popular não era monolítica ou homogênea. (BURKE, 1999: 49).

Segundo o autor, o interesse pela cultura popular teria se desenvolvido especialmente no final do século XVIII. A busca era pelo "natural”, "inculto", "primitivo". Em suma, o primitivismo cultural motivava a descoberta da cultura "popular", "distante", ou "antiga" todas igualadas. O autor observa que praticamente não temos registros das tradições senão aqueles divulgados por seus coletores, que poderiam modificá-los de acordo com aquilo que acreditassem necessário. A própria "descoberta da cultura popular" foi influenciada por movimentos nativistas:

As canções folclóricas podiam evocar um sentimento de solidariedade numa população dispersa, privada de instituições nacionais (...) elas uniam um povo dividido. (...) De maneira bastante irônica a ideia de uma nação veio dos intelectuais e foi imposta ao "povo" com quem eles queriam se identificar. (BURKE, 2010: 18)

Segundo o autor, houve uma série de razões para o interesse pelo povo neste momento específico da história europeia (sécs. XVIII-XIX): razões estéticas, intelectuais e políticas. A principal razão estética era a que se pode chamar de "revolta contra a arte". Escritores, músicos e pintores buscavam inspiração na cultura popular: o pintor Courbet, por exemplo, inspirou-se em xilogravuras populares, ainda que até 1850 não tenha desenvolvido um interesse sério pela arte popular. Houve um movimento dos intelectuais no sentido de valorização do folclórico, do fantástico e da superstição.

Em 1500, desprezavam as pessoas comuns, mas partilhavam de sua cultura. Em 1800, seus descendentes haviam deixado de participar espontaneamente da cultura popular, mas estavam-na redescobrindo como algo exótico e, portanto, interessante. Estavam até começando a admirar o "povo" do qual brotava essa cultura estranha. (BURKE, 1999: 306)

Natalie Zemon Davis também compõe o grupo dos historiadores culturais, focando seu interesse de modo semelhante nas tradições europeias, especialmente nas da França do 
início da idade moderna. Na década de 70 a autora lança Sociedade e Cultura na França Moderna. Este livro é considerado um marco entre os historiadores da cultura, valorizando, assim como Thompson, a "história vista pelos de baixo" ao tratar de pessoas humildes da cidade francesa de Lyon no século XVI. Davis explorou as experiências sociais que constituíram a lógica protestante da época, dando ênfase aos modos de viver e de socializar com o mundo de modo geral, em reuniões, festas, revoltas etc.

Em Culturas do Povo, Davis apresenta uma série de ensaios que segundo ela própria tratam de camponeses e artesãos, ao passo que os poderosos e o clero são descritos do ponto de vista dos "modestos". Para ela,

A cultura oral e a organização social popular eram suficientemente fortes para resistir à mera correção e uniformização vindas de cima (DAVIS, 1990:185).

Interessa-lhe especialmente o estudo da "sabedoria proverbial", o tratamento dos "erros populares" sobre medicina, que se prestam a levantar algumas questões sobre o nosso papel como intérpretes acadêmicos do passado.

No capítulo que trata dos provérbios de Salomão e das respostas de Marcolf ${ }^{4}$ fica clara uma espécie de ressignificação envolvendo uma cultura camponesa e outra erudita, que por vezes se fundem ou se afastam, mesmo que não completamente. Exemplo semelhante de ressignificação pode ser observado em um ensaio sobre o erótico de Carlo Ginzburg (autor que será mais cuidadosamente abordado à frente), ao discutir o resultado do contato entre culturas gerado a partir das relações entre a obra do poeta Ovídio e do pintor Ticiano. ${ }^{5}$

\footnotetext{
${ }^{4}$ No final do século XV foi publicado o livro Os provérbios de Salomão e as respostas de Marcolf, onde o primeiro era apresentado como um rei sóbrio cercado de livros e o segundo, como um homem rústico, descalço e despenteado. Marcolf recriava os ditos de Salomão numa linguagem cotidiana e maliciosa, ou transformavalhes em piadas.

${ }^{5}$ Em seu texto, Carlo Ginzburg levanta questões sobre a interpretação das Metamorfoses de Ovídio nas obras de Ticiano, abordando a questão da figuração erótica no século XVI, e sua relação com a sociedade da época. $\mathrm{O}$ autor ressalta que a Igreja temia essas imagens por proporem de modo deliberado excitar sexualmente o espectador-fruidor, portanto passou a gerenciá-las. De um lado, era uma tentativa de controlar a vida sexual de modo cuidadoso. Por outro, era um propósito de servir-se das imagens para restabelecer uma relação com as massas dos fiéis, pois seria uma reação contra a quebra de hegemonia que as imagens sacras sofreram. Aos poucos essas imagens escaparam dos espaços particulares e do domínio da igreja, passando a ser reproduzidas e distribuídas em maior escala. Esta reprodução, nem tão fidedigna, gerou novos gostos e padrões para a figuração erótica em um público mais ampliado.
} 
Do ponto de vista metodológico, Davis propõe-se a estudar casos ligados por uma cadeia de preocupações históricas que se ramifica. A atenção para dinâmicas de grupos diferentes dentro de uma mesma sociedade aponta, no entanto, para seu afastamento da metodologia marxista de divisão de classes separadas por fatores econômicos. Davis se propôs a tratar de questões de gênero do passado a partir da perspectiva antropológica e de questões relativas às mulheres, especialmente no que tange seu comportamento diante de transformações religiosas.

Também preocupado com a história cultural francesa, destaca-se Robert Darnton. Entre os livros publicados pelo autor, pode ser considerada de especial importância uma coletânea de ensaios, cujo título O Grande Massacre de Gatos e outros episódios da história cultural francesa, já chama atenção para um dos ensaios, Os trabalhadores se revoltam: $o$ grande massacre de gatos na Rua Saint-Sevérin, que pode ser considerada uma importantíssima experiência de interdisciplinaridade entre a história social e a antropologia social. Robert Darnton está ligado à revista dos Annales, que foi fundada em 1929 tendo como principais mentores Marc Bloch e Lucian Febvre. Ele propõe uma tentativa de retomada de uma história reconhecida pelo leitor em versões diferentes da que será por ele relatada com o propósito de iniciar sua análise. Buscando justificar o interesse por trás de um massacre de gatos, o autor trabalha o relato de um operário da época, com o objetivo de interpretar o documento e compreender todo um código social contido naquelas palavras.

A obra de Darnton objetiva uma maneira de tentarmos perceber as classes populares do século XVIII, suas mentalidades, tradições, medos e anseios. No caso do massacre dos gatos ficam claras problemáticas que vão para além da organização de classe dos trabalhadores. Por volta de 1730, operários com péssimas condições de trabalho em uma tipografia da rua Saint-Sevérin, em Paris, perpetraram uma chacina contra os gatos da vizinhança motivados pelo ódio ao patrão e à patroa, que ocupavam o papel de burgueses segundo a estrutura marxista, e adoravam os felinos. Um dia de maior exploração dos trabalhadores foi o estopim de uma revolta de classe na Europa pré-industrial. Mas, para além disso, os documentos informam outro detalhe: durante a matança, e nos dias que se seguiram, os homens riram muito, uma "risada rabelaisiana". 
levam para além das considerações referentes às relações de trabalho no início dos Tempos Modernos, conduzindo-nos ao obscuro tema dos rituais e do simbolismo popular. (DARNTON, 1983: 113)

Darnton não se detém à questão de quem redigiu o relato, estende a análise para a produção artesanal da época e mostra as incontáveis singularidades do momento e do lugar, seguindo por inúmeras superstições, principalmente na fama maligna dos gatos e no hábito bastante comum de torturá-los durante o Carnaval e em outras festas populares.

Carlo Ginzburg produziu a importante obra $O$ queijo $e$ os vermes, focando especialmente o personagem Menocchio. Ela narra o cotidiano, a vida e o julgamento inquisitorial do moleiro de Montereale, zona italiana do Friuli. Domenico Scandella, conhecido por Menocchio, foi perseguido e executado pela Inquisição por disseminar suas ideias heréticas ao povo de sua aldeia. A obra situa-se no século XVI, numa era marcada pela Reforma Protestante e pela difusão da imprensa na Europa pré-industrial. Ginzburg fez um estudo da história cultural e das mentalidades, numa prática de micro-história ${ }^{6}$, que revela as classes subalternas e acaba desenvolvendo uma hipótese geral sobre a cultura popular, na qual trata da influência mútua entre as culturas popular e erudita. O livro discorre sobre possibilidades de como teria o moleiro formulado suas ideias acerca de determinados dogmas religiosos e sobre a criação do mundo. Primeiro o autor compara-o aos grupos heterodoxos: luteranos e anabatistas. Logo percebe que há algumas semelhanças, mas que é improvável a cumplicidade de Menocchio com esses grupos, pois ele ignorava Justificação e Predestinação, temas centrais da Reforma. E por fim, faz uma minuciosa análise dos livros que o próprio acusado confessou ter lido, levando em conta não as páginas lidas, mas a forma como era feita essa leitura, que talvez envolvesse alguma precariedade técnica: a fonte parecia ser menos importante que a rede interpretativa pensada pelo camponês. Menocchio foi, de fato, uma exceção: poucos trabalhadores de fim do século XVI que tiveram acesso a obras semelhantes elaboraram as mesmas ideias que lhe fizeram cair nas malhas da Inquisição. Ao mesmo tempo, a própria existência dessa exceção indica para Ginzburg que havia mecanismos de circulação: seu caso só foi possível porque havia estruturas que o

\footnotetext{
${ }^{6}$ Trata-se de um gênero historiográfico que propõe uma delimitação temática extremamente específica por parte do historiador (inclusive em termos de espacialidade e de temporalidade), mas não se reduz apenas a isto. Em escala de observação reduzida, a análise desenvolve-se a partir de uma exploração exaustiva das fontes.
} 
permitiam. A isso Ginzburg chama de "exceção representativa".

No prefácio da obra em questão, Ginzburg utiliza as expressões "classe subalterna" e "classe dominante" para se referir aos conflitos de interesses postos à sociedade e questiona até que ponto tratar-se-iam de esferas tão separadas:

A essa altura começa a discussão sobre a relação entre cultura das classes subalternas e a das classes dominantes. Até que ponto a primeira está subordinada à segunda? Em que medida, ao contrário, exprime conteúdos, ao menos em parte, alternativos? É possível falar em circularidade entre dois níveis de cultura? (GINZBURG,1998: 17)

A partir daí, o autor levanta a questão da problemática das fontes relacionadas à "cultura subalterna": a imprecisão da oralidade, relatos escritos por indivíduos mais ou menos ligados à cultura dominante e uma série de filtros intermediários - problemática presente no que diz respeito aos relatos sobre o objeto monstruoso entre os séculos XVI e XIX. Para resolver este problema Ginzburg propõe estudar não a "cultura produzida pelas classes populares", mas a “cultura imposta às classes populares". Segundo o autor,

Foi o que Robert Mandrou tentou fazer há uns dez anos com base em uma fonte até aquele momento pouco explorada: a literatura de cordel, isto é, folhetos baratos, impressos grosseiramente (...) vendidos nas feiras ou nos campos por ambulantes. Mandrou, diante de uma lista dos principais temas recorrentes acabou por formular uma conclusão apressada. Essa literatura (...) teria impedido que seus leitores tomassem consciência da própria condição social e política (...) desempenhando, talvez conscientemente, uma função reacionária. (GINZBURG, 1998: 18)

Quanto ao insucesso do trabalho de Mandrou, Ginzburg afirma na sequência:

Identificar a cultura produzida pelas "classes populares" à "cultura imposta às massas populares", decifrar a fisionomia da cultura popular, apenas através das máximas, dos preceitos, e dos contos da Bibliothèque bleue é absurdo. $\mathrm{O}$ atalho indicado por Mandrou para se superarem as dificuldades ligadas à reconstrução de uma cultura oral nos leva na verdade ao ponto de partida. (GINZBURG, 1998: 19)

Ginzburg mostra ter referência na obra de Mikhail Bakhtin para pensar a cultura popular: a inversão de valores brincalhona do carnaval da Idade Média se contrapõe ao dogmatismo e seriedade da cultura das classes dominantes. "Portanto temos de um lado 
dicotomia cultural, mas por outro, circularidade, influxo recíproco entre cultura subalterna e cultura hegemônica." (GINZBURG,1998:19).

Em sua obra A cultura popular na Idade Moderna e no Renascimento, Bakhtin tem por objeto específico de estudo a obra de François Rabelais, para ele nitidamente marcada pela cultura popular. Para melhor compreender a obra rabelaisiana, analisa as diversas manifestações dessa cultura. Em seu livro ele pretende revelar a unidade e o sentido e o sentido da cultura popular, além de seu valor estético. As situações criadas por Rabelais, mais que pura ficção, constituem alusões a certos acontecimentos da vida na corte e fora dela. Muitos de seus personagens são uma verdadeira paródia de pessoas chaves na política do período em que viveu. Utilizando-se desse sistema, Rabelais, descrente do que sua época falava de si mesma e do que imaginava ser, visava lançar um outro olhar, o cômico, sobre os acontecimentos de seu tempo. Para Bakhtin, Rabelais possuía posições avançadas e progressistas para o seu tempo, acreditando que o papado e o império eram instituições ultrapassadas. Nessa obra, ao refletir sobre a cultura popular, o autor, a partir da identificação de algumas manifestações populares na cultura de prestígio do Renascimento, formula seu instrumental teórico de circularidade cultural. De acordo com as suas reflexões, podemos afirmar que não há cultura popular pura, ela se configura pela relação com a cultura, instituições e concepções dominantes, ou seja, a polarização cultural é enganosa, pois as classes dominadas estão em relação com as classes dominantes, partilhando um processo social em comum. A produção cultural é fruto dessa existência em comum, embora os benefícios e o controle sejam repartidos de forma desigual.

Para defender sua tese de circularidade cultural, Bakhtin exemplifica que na religiosidade, muitos líderes protestantes, a fim de tornarem-se mais acessíveis ao povo e obterem sua confiança, passaram a utilizar o cômico em seu vocabulário, em seus panfletos e tratados teológicos. Nesse período, somente quem utilizasse o riso era capaz de aproximarse do povo, que desconfiava do sério e fazia conexões entre a verdade e o cômico. No Renascimento o riso foi incorporado pela grande literatura, pela ciência e pela ideologia. Ainda com relação à linguagem, Bakhtin cita outro significativo exemplo de circularidade cultural: foi na obra de Rabelais que, pela primeira vez, as fontes orais, as palavras da vida popular entraram para o sistema de linguagem escrita e impressa. 
Para Canclini (2000), à exceção do trabalho precursor de Mikhail Bakhtin, apenas recentemente, nas três últimas décadas, surgiu uma preocupação científica com o tema da cultura popular. Grande parte desta bibliografia tende a considerá-la como uma expressão tradicional e subalterna, contrária ao culto, marcado pelo moderno e o hegemônico ${ }^{7}$. Analisando especificamente a situação da cultura popular na América Latina, Canclini conclui que, mesmo em países que adotam em seu discurso oficial uma visão antropológica de cultura, existe uma hierarquia entre os capitais ${ }^{8}$ culturais: a arte vale mais que o artesanato, a cultura escrita mais que a transmitida oralmente. Mesmo nos países em que os saberes e práticas culturais populares, tais como as dos indígenas ou camponeses, foram considerados expressões nacionais, estes capitais simbólicos possuem uma posição secundária, de subordinação.

\subsubsection{Práticas e representações}

O francês Roger Chartier, vinculado à atual historiografia da Escola dos Annales, desenvolve as suas reflexões e críticas acerca da história das mentalidades ${ }^{9}$ e, a partir delas, propõe algumas mudanças no modo de abordar a cultura. Uma de suas primeiras recusas se

\footnotetext{
${ }^{7}$ Com uma orientação claramente marxista, alguns conceitos e teóricos se destacam como grandes influências para os primeiros representantes dos Estudos Culturais: o conceito de hegemonia, por exemplo, associado a Gramsci, vai ser central para descrever as relações de dominação nem sempre aparentes na sociedade. A perspectiva gramsciana da hegemonia abre possibilidades para a compreensão da cultura, visto que não se trata mais de pensar os meios através de sua função ideologizante e dominadora a serviço das elites. Torna-se, outrossim, necessário refletir que o processo de dominação social se dá a partir da hegemonia de uma classe, mas não sem o consentimento e cumplicidade das classes subalternas.
}

\footnotetext{
${ }^{8}$ Bourdieu entende por "capital" todo recurso ou poder que se manifesta em uma atividade social. Assim, além do capital econômico (renda, salários, imóveis), é decisivo para o sociólogo a compreensão de capital cultural (saberes e conhecimentos reconhecidos por diplomas e títulos), capital social (relações sociais que podem ser convertidas em recursos de dominação). Em resumo, refere-se a um capital simbólico (aquilo que chamamos prestígio ou honra e que permite identificar os agentes no espaço social). Ou seja, desigualdades sociais não decorreriam somente de desigualdades econômicas, mas também dos entraves causados, por exemplo, pelo déficit de capital cultural no acesso a bens simbólicos.

${ }^{9}$ Trata-se de uma forma de refletir a história que privilegia os modos de pensar e de sentir dos indivíduos de uma mesma época. Um "estudo das mediações e da relação dialética entre, de um lado, as condições objetivas da vida dos homens e, de outro, a maneira como eles a narram e/ou como a vivem"; é uma modalidade historiográfica que privilegia os modos de pensar e de sentir dos indivíduos de uma mesma época, segundo Roger Chartier, uma história do sistema de crenças, de valores e de representações próprios a uma época ou grupo.
} 
dá com relação à ideia que por muito tempo permeou a história social da cultura, preocupada em caracterizar culturalmente os grupos sociais (erudito versus popular) ou caracterizar socialmente os produtos culturais (elite versus povo). Com isso, Chartier recusa o pressuposto de que os contrastes e as diferenças culturais estejam forçosamente organizados em função de um recorte social previamente constituído. Definir se deve chamar-se popular o que é criado pelo povo ou àquilo que lhe é destinado seria para o autor um falso problema: "Importa antes de mais identificar a maneira como se cruzam e se imbricam diferentes formas culturais”. (CHARTIER, 1990: 56)

Outra noção trabalhada por Chartier é a de "representação". Ela é instrumento de conhecimento mediado, que faz ver um objeto ausente através da sua substituição por uma imagem capaz de o reconstituir em memória e de o figurar tal como ele é.

\footnotetext{
É necessário inscrever a importância crescente adquirida pelas lutas de representações onde o que está em jogo é a ordenação, logo a hierarquização da própria estrutura social. (...) a história cultural pode regressar utilmente ao social, já que faz incidir a sua atenção sobre as estratégias que determinam posições e relações e que atribuem a cada classe, grupo ou meio um ser-apreendido constitutivo da sua identidade (CHARTIER, 1990: 23).
}

Ao reconhecer a fragilidade do esquema de interpretação utilizado pela história social da cultura para abordar os objetos e práticas culturais, Chartier sinaliza para a necessidade de se pensar em outros termos a relação entre recortes sociais e as práticas culturais. Para responder a essa necessidade propõe o deslocamento de uma história social da cultura para uma história cultural do social.

Chartier avança nos estudos da sociedade, não se contentando em voltar o olhar apenas para a cultura de um determinado grupo social, mas expandindo a visão para as trocas entre cultura oral e escrita, estudando como a cultura não letrada pode colaborar com a cultura escrita através das práticas que estas criam na sociedade.

Assim, percebemos como Chartier fazendo uso da oralidade como fonte de análise também volta o olhar para aspectos cotidianos das massas que não eram observados até então. Tudo, dentro da sociedade, pode ser entendido como representação e prática: as formas de poder em todas suas vertentes, seja política ou religiosa, como forma de dominação, de 
organização social ou para diferenciar grupos, as representações estão sempre presentes e lidas entre as linhas de todos os atos que tomamos, seja no campo da coletividade ou da individualidade.

Pensar como essas representações geram as práticas e, principalmente, como essas práticas são interpretadas dentro das sociedades em períodos diferentes, é a proposta de Chartier ao compor essas noções.

O autor também trata da manipulação de documentos clivados a partir de esquemas geradores de classificação:

À partir de ce terrain de travail où se nouent le texte, le livre et la lecture, plusieurs propositions peuvent être formulées qui articulent de manière neuve les découpages sociaux et les pratiques culturelles La première espère lever les faux débats engagés autour de la division, donnée comme universelle, entre objectivité des structures (qui serait le territoire de l'histoire la plus sûre, celle qui, en maniant des documents massifs, sériels, quantifiables, reconstruit les sociétés telles qu'elles étaient véritablement) et la subjectivité des représentations (à laquelle s'attacherait une autre histoire, vouée aux discours et située à distance du réel). (CHARTIER, 1989: 1513)

Chartier critica a ideia estereotipada da oposição entre uma objetividade estrutural e quantificável que pretende reconstruir a realidade tal como verdadeiramente foi e uma subjetividade das representações, preocupada com discursos e situada à distância do real. Além disso, Chartier sustenta a ideia de que as clivagens culturais costumam ser equivocadamente organizadas pelo viés do recorte social, quando, na verdade, esta perspectiva deveria ser invertida.

As discussões propostas até aqui levantam questionamentos fundamentais a esta pesquisa: existe de fato uma "cultura popular"? E caso admitamos que sim, ela diverge completamente de uma "cultura erudita" (também questionável) como sistemas culturais autônomos? O que se quer dizer com "popular"? De que forma essas "nuances culturais" se pronunciam quanto à ideia das formas insólitas, híbridas, monstruosas ou fantásticas? E então partimos para novas questões, a começar por como nomear essas criaturas? 


\subsubsection{Definindo e localizando o cordel}

De acordo com diversos autores o cordel aparece inicialmente na França do século XVII como objeto editorial de baixo custo e larga circulação. Apesar desta característica editorial e comercial de divulgação maciça, não é verdade que tais livros fossem dirigidos especificamente para um público de "cultura popular", urbano ou camponês. O objeto do cordel era composto por textos de origens diversas, visando públicos particulares, sendo os gêneros mais vendidos as obras de cunho religioso, os manuais de conduta e a devoção, ensinamentos da bíblia, Evangelhos e Salmos, a literatura romanesca e jocosa, as vidas dos santos, os romances de cavalaria, os contos de fadas e as peças. Tanto os textos de ficção como parte dos religiosos eram formas adaptadas de textos que passam por cultos, é o que comprovam pesquisas de historiadores, como relata Chartier (1990: 165-187). Era comum que os editores promovessem modificações nos textos a fim de torná-los mais vendáveis. $\mathrm{O}$ público principal esteve inicialmente nos burgos, mas expandiu-se para o campo, o que, aparentemente, fez com que as elites começassem a desprezar os livros de cordel, seja pela condenação dos seus textos, seja pelo descuido de sua forma, o que também não significa que sua circulação restringiu-se.

Após o surgimento da imprensa, por volta de 1450, os poemas populares começaram a ser impressos em pequenos livrinhos e em papel de má qualidade, para que o preço fosse acessível à população de baixa renda, que se tornou um de seus maiores consumidores. $\mathrm{Na}$ França, a cidade de Troyes ficou famosa em 1483, por publicar folhetos e almanacs populares ou literatura de colportage, vendidos por ambulantes, principalmente nas aldeias camponesas. A produção portuguesa de cordel pode ser situada num contexto mais alargado de publicações semelhantes que existiram, durante séculos, em diferentes países europeus, como é o caso da Bibliothèque bleue francesa, dos pliegos sueltos espanhóis e dos chapbooks ingleses, com características e objectivos semelhantes, apesar das inúmeras particularidades que distinguem estas práticas. Além disso, a literatura de cordel portuguesa revelaria ainda, determinate influência sobre a literatura de cordel brasileira, ainda em curso.

Não há entre estudiosos um consenso quanto às origens da literatura de cordel no Brasil, particularmente no nordeste brasileiro. "Em geral, suas origens são relacionadas ao hábito de contar histórias que aos poucos começaram a ser escritas e difundidas pela 
imprensa. Câmara Cascudo (1994/1953) refere-se a livros tradicionais, de grande difusão e prestígio, de origem europeia, e também a obras da literatura erudita brasileira, que foram adaptados para o formato de folhetos" (GALVÃO, 2006: 29).

O trabalho da portuguesa Ana Margarida Ramos, Os monstros na literatura de cordel portuguesa do século XVIII, analisa um conjunto de folhetos da literatura de cordel portuguesa em verso ou prosa que tratam da temática do ser monstruoso. Seu livro envolve o estudo de um contexto mais alargado de publicações principalmente portuguesas, mas também de outras localidades. Para ela, os cordéis podem ser vistos como herdeiros de tradições culturais e literárias antiquíssimas - formas embrionárias de uma literatura de massas que, a partir do século XIX, conheceu grande desenvolvimento e sucesso a partir de fórmulas editoriais semelhantes. Segundo Ramos:

A caracterização, ainda que sumária, destas diferentes realidades onde o cordel conheceu um êxito assinalável durante muito tempo permite perceber a existência de práticas afins, além de uma ligação forte a uma matriz literária oral, comum a diferentes países (RAMOS, 2008: 13).

No entanto, a filiação direta entre o cordel português e o folheto brasileiro não é consenso entre autores. Márcia Abreu, em sua tese de doutoramento, problematiza a origem portuguesa dos folhetos de cordel brasileiros. Ao confrontar a literatura de cordel portuguesa à produção brasileira do mesmo gênero concluiu que faltavam estudos, quer no Brasil quer em Portugal, demonstrando claramente que a literatura de cordel portuguesa podia ser apresentada como "fonte, origem ou matriz cultural" (ABREU, 1999: 15) da sua congênere brasileira, ainda que vários autores defendessem que o material português sofreu alterações em contato com a realidade brasileira: fala-se em "adaptação", "recriação", "transformações", "desdobramentos", fusão entre a "literatura popular ibérica" e a "prática dos poetas improvisadores" (ABREU, 1999: 17). Segundo ela:

Produções realizadas fora do padrão culto europeu são desconsideradas ou relegadas aos estudos folclóricos - mais modernamente, aos estudos de cultura popular. Apropriando-se do modelo interpretativo que vincula a produção intelectual dos países colonizados e periféricos a um original desenvolvido nos grandes centros, os folcloristas e críticos buscam identificar as produções culturais brasileiras a similares europeus. (ABREU, 1999: 126). 
A literatura de cordel brasileira apresentou, desde o surgimento, forte componente oral, além de sua manifestação através do repente ${ }^{10}$, o que leva grande número de estudiosos brasileiros a associarem-na mais diretamente à tradição oral nordestina. Mas a discussão não para por aí:

Francisco das Chagas Batista (1998/1929), por sua vez, traz diversos exemplos de cantadores que transcreviam seus versos para se apresentar nas cantorias e, por vezes, os enviavam a outros poetas através de cartas. Muitos destes desafios, como demonstram Leonardo Mota, Câmara Cascudo, Silvio Romero e Pereira da Costa, tinham origem portuguesa. Esses autores realizaram comparações entre variantes formas de poesia oral portuguesas e brasileiras. Na verdade, o que parecia ocorrer era uma circularidade entre as diversas formas de cultura (inclusive as indígenas, africanas e de outros povos) em um Brasil marcado pela oralidade (GALVÃO, 2006: 31)

Quanto a sua importância, vale a pena destacar sua aproximação a uma espécie de “jornalismo rudimentar" e sua ampla circulação, especialmente entre as décadas de 1940 e 1950:

A Literatura de Cordel constituiu-se no mais extraordinário meio impresso de comunicação no Brasil (...) Ela atingiu, entre as décadas de 1940 e 1950, audiência calculada em 30 milhões de pessoas, quase um terço da população brasileira. Os próprios poetas, semianalfabetos, escreviam ou pediam aos outros para escreverem e editarem sua produção, parte dela ilustrada na xilogravura. Os primeiros folhetos eram publicados em tipografias e se espalhavam na região nordestina, pelas praças e feiras. Era um sistema de jornalismo matuto (...). Alguns poetas tinham suas próprias gráficas, como Leandro Gomes de Barros. Com seu falecimento em 1918 João Martins Athayde comprou seu acervo e transformou a produção rústica em atividade de considerável porte no Recife, montando a maior folheteria do nordeste (FRANKLIN, 2007: 20)

Por ora, tais considerações parecem suficientes para compreendermos um pouco sobre a extensão do fenômeno do cordel no Brasil e de seus diálogos com outros suportes. Podemos, no entanto nos perguntar afinal: que tradição brasileira é essa expressa pelos

\footnotetext{
${ }^{10}$ Sob essa rubrica do cordel encontra-se o repente, um verso feito de improviso, instantaneamente, na agilidade mental do repentista, oferecido ao consumo dos presentes. Também é conhecido como improviso. Fazer repente é a arte de falar elaborando ideias, dentro de métrica e rima rigorosas. (RIBEIRO, 1995)
} 
folhetos?

\subsubsection{A cara do Brasil e um nordeste multifacetado}

Comemorações relativas ao boi, ao Divino Espírito Santo, tradições carnavalescas ou juninas seguem se repetindo anualmente, mesmo nos espaços mais urbanizados do país. Os anos noventa parecem lançar luzes ao forró, ao xaxado, ao maracatu. O Mangue Beat nasce fundindo notas da musicalidade de parte do nordeste às guitarras e aos ruídos da cidade urbanizada. A moda e a alta costura procuram suas referências em matrizes "populares". Xilógrafos, como J. Borges e o próprio cordel, cantado ou no folheto, passam a retomar a visibilidade, aparentemente perdida há algumas décadas. Seria este o retrato de uma cultura nacional?

As artes brasileiras, especialmente a literatura e seus diversos autores, desde o romantismo do início século XIX, demonstraram preocupação com a criação de algo que focasse o Brasil, retratando-o. Vemos nos anos 1920, em São Paulo, uma retomada crítica desta tendência, trazida à tona pelo Movimento Modernista. Mário de Andrade seria um dos primeiros intelectuais a empreender pesquisas sistemáticas sobre manifestações populares da cultura em todo o Brasil. Sua ideia era construir uma arte nacional erudita a partir daqueles elementos populares. No mesmo contexto, o também modernista Oswald de Andrade lançou o Manifesto Antropofágico, que propôs a "deglutição", ou absorção seletiva de ideais estrangeiros, bem como sua transformação e adaptação a nossas necessidades.

O Tropicalismo, surgido nos anos de 1960, atualizou a vertente antropofágica do Modernismo, articulada nos anos de 1920 por Oswald de Andrade. Já o movimento Armorial $^{11}$ e os valores ético-estéticos defendidos por Ariano Suassuna poderiam ser

\footnotetext{
11 O Movimento Armorial surge em Pernambuco na década de 1970 como um desdobramento das ideias nacionalistas daquela vertente do modernismo, mas também profundamente inspirado pela ideia de brasilidade nordestina tributária da obra de Freyre. Propõe-se a construir uma arte erudita brasileira a partir das raízes populares. O sertão nordestino seria o lócus privilegiado da, por eles denominada, genuína cultura popular, onde
} 
identificados como um desdobramento do ideário modernista de Mário de Andrade na busca de uma reconfiguração da identidade nacional. Ao tentarmos situar o movimento armorial dentro da tradição intelectual brasileira, identificamos não apenas afinidades com o Modernismo de Mário de Andrade, mas também com o regionalismo de Gilberto Freyre. Guardadas as devidas especificidades históricas, há vários elementos comuns entre a estética marioandradeana - que dá suporte à construção de uma concepção de identidade nacional e o ideário armorial, que propõe uma recriação erudita da cultura popular com o mesmo propósito. Suassuna, no entanto, teria partido para uma "sacralização" do popular "puro" (BEZERRA, 2009).

Contemporânea aos modernistas, uma das mais importantes obras para a constituição de uma imagem de país foi "Casa-grande e senzala", do sociólogo pernambucano Gilberto Freyre. Nela, Freyre desmonta o argumento de que a miscigenação étnica seria a grande responsável pelo atraso do Brasil, conforme pregavam as teorias eugênicas do século XIX. Por meio dessa interpelação Freyre abarca de realidades múltiplas e dispersa às culturas populares e constrói um discurso identitário unificado em torno de uma ideia de nação, tornando-se artífice do regionalismo nordestino.

Durval Muniz critica em sua tese de doutorado o regionalismo freyreano e a ideia de "brasilidade nordestina" por ele defendida. Inspirado em Foucault, para quem poder é "algo que circula". Muniz compreende os nordestinos como participantes da construção e reprodução da identidade que lhes confere um papel inferior no "dispositivo da nacionalidade" brasileira. Nas palavras do autor:

Nós, os nordestinos, costumamos nos colocar como os constantemente derrotados, como o outro lado do poder do Sul, que nos oprime, discrimina e explora. Ora, não existe esta exterioridade às relações de poder que circulam no país, porque nós também estamos no poder, por isso devemos suspeitar que somos agentes de nossa

\footnotetext{
o artista nacional deveria buscar os elementos para a elaboração de sua obra. Lá repousaria a matéria-prima capaz de revelar a verdadeira face do Brasil. O ideário armorial vai reunir em torno de seu mentor, Ariano Suassuna, intelectuais e artistas locais ligados às mais diversas formas de expressão. No entanto, um dos aspectos que vai adquirir vulto no debate cultural tanto local quanto nacional é exatamente a postura do seu líder diante de fenômenos como a internacionalização da cultura e a cultura de massa (BEZERRA, 2009).
} 
própria discriminação, opressão ou exploração. Elas não são impostas de fora, elas passam por nós (ALBUQUERQUE JÚNIOR, 2001: 21).

Para o autor a repetição de um discurso da intelectualidade do início do século XX, ligada à elite cafeeira e incorporado no próprio nordestino acabou por condená-lo a um estereótipo que permanece até a atualidade.

Definir a região é pensá-la como um grupo de enunciados e de imagens que se repetem, com certa regularidade, em diferentes discursos, em diferentes épocas, com diferentes estilos e não pensá-las numa homogeneidade, uma identidade presente na natureza. O Nordeste é tomado, neste texto, como invenção, pela repetição regular de determinados enunciados, que são tidos como definidores do caráter da região e de seu povo, que falam de sua verdade mais interior. (...) Nossa preocupação com o poder não implica, no entanto, uma análise do que está oculto sob os textos ou imagens, mas ao contrário, do que elas criam em sua exterioridade e da própria diferença com que descrevem. Não tomamos os discursos como documentos de uma verdade sobre a região, mas como monumentos de sua construção de caráter da região e de seu povo, que falam de sua verdade mais interior. (ALBUQUERQUE JÚNIOR, 2001: 24)

Mais que isso, para Albuquerque Jr., a insistente necessidade de tipificar culturas leva à “invenção de tradições".

A busca das verdadeiras raízes regionais, no campo da cultura, leva à necessidade de inventar uma tradição. Inventando tradições tenta-se estabelecer um equilíbrio entre a nova ordem e a interior; busca-se conciliar a nova territorialidade com antigos territórios sociais e existenciais. A manutenção de tradições é, na verdade, sua invenção para novos fins, ou seja, a garantia da perpetuação de privilégios e lugares sociais ameaçados. (ALBUQUERQUE JÚNIOR, 2011: 90).

As fontes utilizadas em sua pesquisa foram desde o discurso acadêmico, passando pela publicação em jornais de artigos ligados ao campo cultural, à produção literária 
e poética de romanistas e poetas nordestinos ou não, até músicas, filmes, peças teatrais, que tomaram o Nordeste por tema e o constituíram como objeto de conhecimento e de arte. Tais manifestações reproduziriam o discurso de uma elite intelectual ameaçada que tem como objetivo manter o poder. Neste sentido, também o cordel estaria inserido na reprodução de discursos, ainda que numa leitura mais negativa que a da transgressão bakthiniana.

Enfim, quanto à imagem de país, a conclusão a que chegamos é a de que a ideia de uma cultura brasileira, ou mesmo de nordeste, já seriam de início bastante discutíveis. Enquanto Muniz aposta em um nordeste cuja imagem não estereotipada ou imposta ainda está por vir, talvez o mesmo possa ser esperado a respeito da própria ideia de brasilidade, ou melhor, de brasilidades, no plural, já que qualquer tentativa de homogeneização dos costumes, tradições e culturas clivadas no espaço a que chamamos Brasil seriam tão somente superficiais. Nem por isso, tudo o que se produziu no campo das artes de maior ou menor prestígio desde o século XX deve ser subestimado, como se por traz dessas produções também não houvesse sujeitos ativos e desejosos de escrever suas próprias histórias. É pressuposto aqui que poeta e leitor não são tábulas rasas.

\title{
3.1.6. O cordel brasileiro e os seres insólitos
}

\author{
Cara de cobra \\ cobra! \\ Olhos de louco \\ Louca! \\ Testa insensata \\ Nariz Capeto \\ Cós do Capeta \\ Donzela rouca \\ Porta-estandarte \\ joia boneca \\ De maracatu! \\ (Manuel Bandeira)
}

O surgimento do cordel no Brasil é controverso: para alguns, o primeiro folheto de que se teve tem registro foi de autoria de Leandro Gomes de Barros, e data de 1893 (TERRA, 1983: 17), mas estudos recentes apontam para outras descobertas, como a de um folheto publicado no Recife, em 1865 (LUNA E SILVA, 2010: 74). O auge da literatura de cordel no Brasil ocorreu na década de 1930. Nessa época ocorreu a montagem das redes de produção 
e distribuição dos folhetos, centenas de títulos foram publicados, um público foi constituído e o editor deixou de ser exclusivamente o poeta. Entre 1930 e 1940, o cordel foi importante veículo de comunicação, antecipando-se muitas vezes com relação aos jornais. Na década de 1960, com os avanços dos meios de comunicação e de entretenimento de massa, passou por um estremecimento, mas conseguiu conviver paralelamente às novas mídias. $\mathrm{O}$ folheto de feira voltou a tomar fôlego na década de 1970 (GALVÃO, 2010: 33-34). Muitos são reedições ou releituras de folhetos das décadas anteriores e foram mantidos por colecionadores, que acabaram cedendo estes materiais a universidades para que fossem estudados.

A Fundação Casa de Rui Barbosa indica a existência de três gerações de poetas de cordel no Brasil (das quais duas serão citadas aqui por conta de sua maior relevância para este trabalho). Os artistas da primeira geração $(1900-1920 / 30)^{12}$ definiram as formas de produção e distribuição da literatura de cordel, estilos, regras de gênero e tomaram de empréstimo elementos típicos da transmissão oral. Foi essa condição de oralidade, de uma literatura feita mais para ser memorizada, cantada e fruída coletivamente do que para ser lida individualmente, que permitiu ao cordel alcançar um público cada vez mais amplo, formado, em sua maioria, por analfabetos e semianalfabetos. Inicialmente foram listados alguns exemplares nacionais, datados especialmente a partir da década de 1960 e escolhidos especialmente por conta de seu recorte temático: a abordagem de seres monstruosos. Verifica-se, desde já, que para além das dificuldades relacionadas, como a identificação da autoria dos cordéis, há especial dificuldade em sua precisa localização temporal, já que suas datas de publicação raramente aparecem veiculadas no material. Entre seus principais representantes, temos Leandro Gomes de Barros, João Melquíades, Ferreira da Silva, Severino Milanês da Silva e outros.

A Segunda Geração (1920/30 em diante) é constituída por poetas que começam a ingressar no mundo da produção do cordel a partir da década de 1930. É influenciada por histórias já narradas nos folhetos e decidiram reescrevê-las, inserindo-as nos seus próprios contextos. Nesse processo, que pode ser considerado de transição, antigos personagens

\footnotetext{
12 Informação extraídas do site da Fundação Casa de Rui Barbosa (www.casaruibarbosa.gov.br - última atualização no dia 28/10/2015).
} 
reaparecem em novas histórias ao mesmo tempo em que inúmeros novos personagens passam a integrar a galeria de tipos da literatura de cordel. Entre seus principais representantes contam-se José Soares, Minelvino Francisco Silva, Rodolfo Coelho Cavalcanti, José Pacheco, entre muitos outros.

Câmara Cascudo afirmava que os assuntos presentes nos cordéis são infinitos (...) A partir das temáticas mais recorrentes encontradas nos folhetos seus estudiosos buscam classifica-los em tipologias (...). Carlos Azevedo, por exemplo, divide a literatura de cordel em ciclos (...) Manuel Cavalcante Proença classifica a literatura popular em três grandes grupos9...) Marlyse Meyer em dois. (GALVÃO, 2006: 36).

Esta pesquisa optou pelo recorte temático em torno de seres monstruosos, que apesar de pouco tradicional mostrou-se eficiente no esmiuçamento de questões relativas a alguns trânsitos de saberes.

O acervo de Raymond Cantel, alocado na Universidade de Poitiers, as coleções de Flávio Motta e Ruth Terra, alocadas no Instituto de Estudos Brasileiros da Universidade de São Paulo, e os folhetos do acervo digital da Fundação Casa de Rui Barbosa, foram os examinados neste trabalho. A análise constatou cerca de 100 folhetos tratando do corpo monstruoso em meio a esses arquivos. Apesar de nem todos serem datados, é possível presumir que tenham sido publicados especialmente entre as décadas de 1960 e 1980. Infelizmente, pouquíssimo material anterior a esse período foi conservado. A retomada das publicações foi animada principalmente pelo interesse de intelectuais e turistas. Essa fase suscita uma acalorada discussão: seria o cordel objeto de uma "cultura popular" ou de uma "cultura letrada"? A ideia de circularidade cultural, tal como concebida por Carlo Ginzburg, no prefácio à edição italiana de $O$ queijo e os vermes, oferece respostas dotadas de certa complexidade a esta pergunta, afinal, os cordéis jamais pertenceram a uma cultura exclusiva e homogênea, pelo contrário: é notável a incorporação de elementos do cânone literário, relidos a partir de realidades locais.

Ainda em Ginzburg, a circulação entre os saberes das classes subalternas e da dominante pode ser observada em seu ensaio sobre o erótico, onde defronta a obra do poeta Ovídio com a do pintor Ticiano. O autor levanta questões sobre a interpretação das 
Metamorfoses de Ovídio nas obras do pintor, abordando a questão da figuração erótica no século XVI e sua relação com a sociedade da época. Aos poucos, essas imagens escaparam dos espaços particulares e do domínio da igreja, passando a ser reproduzidas e distribuídas em maior escala. Essa reprodução, nem tão fidedigna, gerou novos gostos e padrões para a figuração erótica em um público mais ampliado (GINZBURG, 1989: 122). Em semelhante espírito, a historiadora Natalie Davis discute o caso de Salomão e Marcolf, ilustrativo do trânsito de saberes que resiste à mera correção e uniformização vindas de cima (DAVIS, 1990: 185)

A ressignificação de uma "arte dominante" ou "vinda de cima", nos moldes propostos pelos autores, também se aplica aos cordéis coletados. Muitos dos folhetos analisados se iniciavam com um clamor às musas ou a outras entidades místicas a quem se pede a inspiração em um claro diálogo com a "invocação", recurso típico da literatura épica clássica. Mas como se comportam os folhetos selecionados com relação a tantos trânsitos culturais? Sem a pretensão de desvendar todos os enlaces relevantes para a compreensão deste fenômeno esboçaremos a seguir alguns apontamentos, por meio de uma proposta de classificação tipológica e de breves análises de trechos considerados exemplares para o entendimento de cada conjunto.

\subsubsection{Tipologia do caso brasileiro}

A pesquisa optou por dividir os folhetos selecionados em três grandes grupos. Os dois primeiros, mais homogêneos tratam de nascimentos e de transformações insólitas. O terceiro, mais diversificado, trata de estranhas aparições, de monstros e de criaturas fantásticas basicamente. Com objetivo de facilitar a visualização de cada grupo que compões o corpus, os títulos em questão serão listados grupo a grupo. Dada a grande quantidade de títulos, apenas alguns poemas, considerados bons exemplares de seus agrupamentos serão comentados.

Blasfêmias contra Deus e os santos, a insatisfação desafiadora de mulheres que não conseguem gerar crianças, ou mesmo a degradação moral da humanidade, dão origem a bebês disformes, híbridos, endemoniados e frequentemente associados ao apocalipse em cordéis de 
poetas bastante conhecidos, como Abraão Batista e José Soares. Já metamorfoses motivadas por comportamentos "transviados" e pela falta de fé no poder divino, ou em ícones da religiosidade católica nordestina, como Padre Cícero e Frei Damião, estão presentes em poemas de João de Barros, Pedro Bandeira, entre outros. Há ainda a referência a gigantes e monstros de lugares estranhos, seres encantados e aparições enigmáticas. Algumas dessas características se repetem em uma ou mais tipologias. Seguem os agrupamentos propostos. 


\subsubsection{Nascimentos}

1. BARROS, João A. de Bebê diabo apareceu em São Paulo. S.1.: s.n., 19--. (Acervo Raymond Cantel).

2. BARROS, João A. de. Os primogênitos do rapaz que casou com uma porca, ou a porcaria de Romeu. Recife: s.n., circa 1950.

3. BATISTA, Abraão. O fenômeno do bode que nasceu metade gente metade bode. Juazeiro do Norte: s.n., 1975. (Acervo Raymond Cantel).

4. BATISTA, Abraão. O menino Monstro. Juazeiro do Norte: Tipografia São Francisco, 1970. (Acervo Raymond Cantel).

5. BATISTA, Abraão. O menino que nasceu com o coração do lado de fora. Juazeiro do Norte: Tipografia São Francisco, 1976. (Acervo Raymond Cantel).

6. CAVALCANTE, Rodolfo Coelho. A criança que nasceu com duas cabeças e três braços em Pernambuco. Jequié: s.n., 19--. (Acervo Raymond Cantel).

7. CAVALCANTE, Rodolfo Coelho. A mulher que deu a luz a uma cobra porque zombou do Bom Jesus da Lapa. Salvador: Agência de Folhetos, 1976. (Acervo Raymond Cantel.).

8. CAVALCANTE, Rodolfo Coelho. Menino de dois mêses que está falando em Pernambuco. . S.l.: s.n., 19--. (Coleção Ruth Terra).

9. D’ALMEIDA FILHO, Manoel. O exemplo do menino que nasceu com duas cabeças. S.1.: s.n., 19--. (Acervo Raymond Cantel).

10. FERREIRA, Severino Amorim. Estória da criança que nasceu com quatro braços, quatro pernas e duas cabeças, falou três horas e morreu. S.1.: Manoel Caboclo e Silva, circa 1960. (Acervo Raymond Cantel).

11. MOSSORÓ, Antônio Lucena. Um cabeludo que deu a luz a um cururu em Feira de Santana. (FL)

12. OLIVEIRA, Severino Gonçalves de. O menino que nasceu barbado. S.1.: s.n., 19--. (Acervo Raymond Cantel).

13. SALES, F. Exenplo das crianças que nasceram ligas da em Belo Jardim. S.1.: s.n., 19--. (Acervo Raymond Cantel).

14. SANTANA, Braulio Teixeira. O monstro filho de um casal de irmãos. S.1.: s.n., 1960, (Acervo Raymond Cantel).

15. SANTOS, Vidal; VIANA, Arievaldo. O príncipe das sete capas. Mossoró: Editora Queima-Bucha, 2007. (Contos de Cascudo em Cordel).

16. SILVA, Gilberto Severino da. A menina que nasceu em Minas Gerais, com quatro olhos, duas bocas, duas ventas, quatro orelhas e dez dedos em cada mão, Acervo Raymond Cantel.

17. SILVA, J. B. O maior exemplo do mundo, o menino que nasceu cabeludo. S.1.: s.n., 19--. (Acervo Raymond Cantel). 
18. SILVA, João Vicente da. As proesas de bebê diabo que agora pelo mundo anda a procura do pai. S.1.: s.n., 19--. (Acervo Raymond Cantel).

19. SILVA, Manoel Caboclo e. O menino que nasceu com a pintura do cão. Juazeiro do Norte: s.n., 1976. (Acervo Raymond Cantel).

20. SOARES, José. A menina fenômeno foi moça com 10 meses, em Arapiraca. S.1.: s.n., 19--. (Coleção Ruth Terra).

21. SOARES, José. A mulher que deu a luz a um satanás. Recife: s.n., 1975. (Acervo Raymond Cantel).

22. SOARES, José. O menino que nasceu com a cabeça nas costas. Recife: s.n., 1974. (Acervo Raymond Cantel).

23. SOARES, José. O monstro de São Paulo. Recife: s.n., 1977.

24. SOUZA, Antonio Patricio de. O bebê Diabo: A história do menino que nasceu com 2 chifres e peludo em São Bernardo do Campo - São Paulo. Campina Grande: Folhetaria Estrela do Oriente, 1975. (Acervo Raymond Cantel).

Ainda que há muito consolidado o divórcio entre religião e ciência, já no século XX, é possível que alguns desses relatos de nascimentos e transformações monstruosos decorrentes de intervenções divinas ou diabólicas fossem tidos como verídicos (mesmo que desacreditados como impossíveis pela medicina). Não foram raras as capas de jornais ditos "populares" que noticiavam acontecimentos extraordinários à exaustão. Em 11 de maio de 1975, o jornal Notícias Populares estampou em sua capa a lúgubre manchete: "Nasceu o Diabo em São Paulo", sobre o suposto nascimento de uma criatura com características sobrenaturais em São Bernardo do Campo (SP). O misterioso parto do bebê diabo rendeu ao jornal 27 reportagens que alavancaram suas vendas, chegando a ultrapassar o dobro de sua tiragem comum. A primeira reportagem explorou o mistério e o medo logo de início:

\footnotetext{
Durante um parto incrivelmente fantástico e cheio de mistérios, correria e pânico por parte de médicos e enfermeiros, uma senhora deu à luz num hospital de São Bernardo (SP) a uma criatura [...] com aparência sobrenatural que tem todas as características do Diabo em carne e osso. O bebezinho já nasceu falando e ameaçou sua mãe de morte, tem o corpo totalmente cheio de pelos, dois chifres pontiagudos na cabeça e um rabo de aproximadamente cinco centímetros, além de olhar feroz que causa medo e arrepios (Notícias Populares, 11/05/1975).
}

O jornal, que circulou em São Paulo entre 15 de outubro de 1963 e 20 de janeiro de 2011, era conhecido por suas manchetes sensacionalistas. Seu slogan, entretanto, era "nada mais que a verdade". Era publicado pelo Grupo Folha, mesma empresa que publica os jornais 
Folha de S. Paulo e Agora São Paulo, considerados veículos de credibilidade. Frequentemente, suas reportagens pareciam fundir realidade e fantasia em um emaranhado de tramas grotescas que não raro buscavam se legitimar a partir da apresentação de testemunhas ou depoimentos de figuras de autoridade. Desde que as reportagens tivessem apelo junto ao público-alvo, qualquer notícia era válida para o grupo que comandava o jornal:

Figuras folclóricas como a mula sem cabeça, as almas penadas, os monstros e os demônios, eram personagens importantes do Notícias Populares (...). Na redação ninguém discutia se era certo ou errado publicar notícias sobre essas esquisitices sempre baseadas em boatos e lendas - a maioria dos leitores do jornal realmente acreditava nas aparições. Eram relatos frequentes nas comunidades pobres, principalmente com a mistura de culturas diferentes em metrópoles como São Paulo (CAMPOS JÚNIOR et al., 2011: 95).

Em seu prefácio à edição de 2011 do livro de onde se extraiu essa citação, o jornalista Marcelo Coelho chama os repórteres e diretores do jornal de "voz dos debaixo", e atribui o fechamento da publicação, entre outros motivos, à ascensão da televisão, com seu “jornalismo arrepiante" e tratamento do grotesco em reality shows, afirmando que "o mundo da sensação" coube melhor na televisão que no jornal.

Não se pretende aqui estabelecer julgamentos éticos a respeito do papel do jornal Notícias Populares, mas refletir a respeito de verdade e verossimilhança em publicações que chegaram a ser contemporâneas. O jornal é, sem dúvida, um suporte dotado de maior credibilidade, mesmo quando dito "popular" (e vale ressaltar que não há dados que invalidem a existência de um público dominante que também se interessasse pela publicação), se comparado a folhetos em versos que já não têm a mesma função comunicacional que nos anos de 1930 ou 1940. Se, por um lado, não é possível afirmar que tanto produtores, quanto leitores da literatura de cordel acreditavam, de fato, nas ocorrências monstruosas e em sua relação com a intervenção divina, por outro, é inegável o interesse dos consumidores pela temática, assim como no caso do jornal. $\mathrm{O}$ insólito se manteve fixado à curiosidade humana, à revelia do que fosse determinado pela ciência formal. Retomando Bakhtin:

(...) Por trás das mais fantásticas imagens desenham-se acontecimentos reais, figuram pessoas vivas, residem a grande experiência pessoal do autor e suas observações precisas”. (BAKTHIN, 1993: 385) 
Observemos, pois, os poemas que seguem:

\author{
O menino que nasceu barbado \\ "Um dia João Conrado \\ disse ao outro criticando \\ Dizem que Jesus tem mãe \\ Eu só fico acreditando \\ se minha mulher der a luz \\ uma criança falando \\ (...) \\ Foi mãe de um belo menino \\ gordo, nutrido e corado \\ com um burcinho de barba \\ para ser mais assinalado. \\ (...) \\ O menino levantou-se \\ ficou de pé sobre a cama \\ sorriu e depois sentou-se \\ e disse para a mãe dele \\ o tempo bom acabou-se. \\ (...) \\ Jesus mandou avisar (...) \\ que vai surgir uma guerra \\ (...) \\ quando a besta-fera chegar \\ ninguém não tem paradeiro."
}

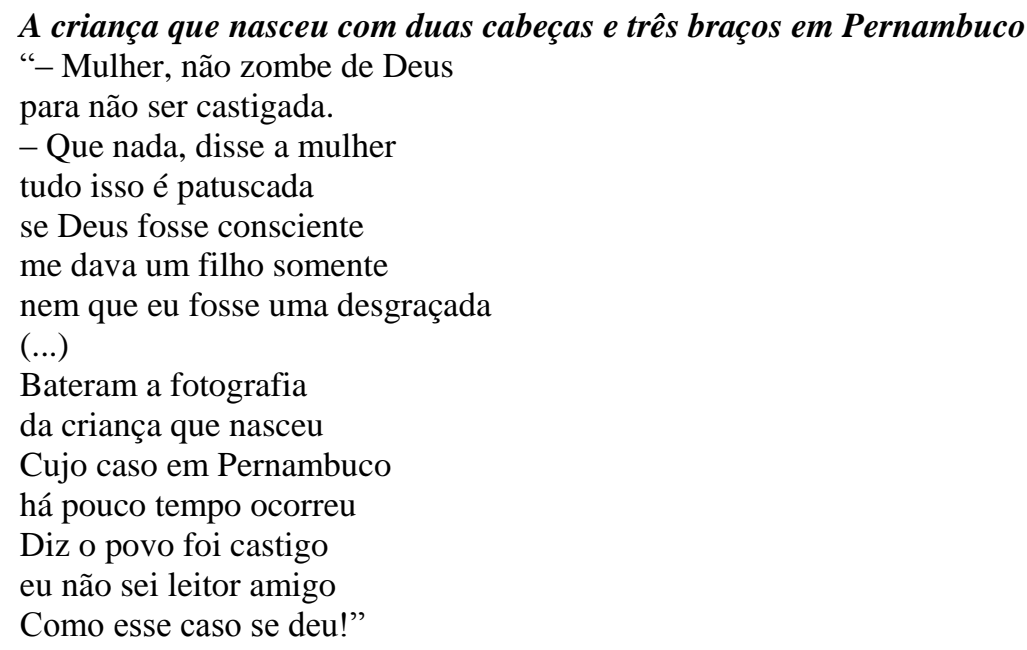

Por vezes há marcas de validação dos relatos: datas, testemunhas, presença da imprensa "Bateram a fotografia/da criança que nasceu". Ainda que isso não se verifique em ambos exertos, faz-se premente mencionar que, no conjunto dos folhetos selecionados, e não apenas nos poemas aqui observados é possível constatar o predomínio do "pecado" feminino como causador do mau nascimento, caso de A criança que nasceu com duas cabeças e três 
braços em Pernambuco. Há relatos, no entanto de que esse modo de encarar o mau nascimento, dataria de antigas tradições:

Toda uma tradição que vai até ao século XVII associa o nascimento dos monstros à "podridão" matricial. Existe uma relação muito direta entre os nascimentos monstruosos e a devassidão do desejo feminino (...) a devassidão é uma das causas da existência de monstros (...) A sobrecarga metafórica tem um efeito de “corrupção" no corpo do embrião, tornando-o monstruoso (...) A metáfora adere à coisa, por sua vez, se transforma em signo. (GIL, 2006: 86)

José Gil segue chamando atenção para modelos interpretativos do mau nascimento envolvendo também animais - Ocorrência que pode ser observada no corpus selecionado por esta pesquisa:

Há contos populares em que este tema quase universal do folclore se desenvolve através de fases sucessivas: após o nascimento da criança monstruosa (criançaporco, criança-serpente), mostram etapas do desenfeitiçamento do menino-mostro no sentido inverso das fases de iniciação da rapariga com quem se casa. No final, o porco transforma-se novamente em homem e a moça que havia suprimido seus desejos, pode agora casar-se verdadeiramente com ele (GIL, 2006: 89).

Nos cordéis brasileiros, no entanto, nem sempre há a redenção, mas por vezes há a presunção da inocência da mãe do feto, e de suas famílias. A lógica é mais associada a uma religiosidade cristã que vê em tais ocorrências o pecado e mesmo sinais do apocalipse.

\section{Criança que nasceu cabeluda}

Em uma família humilde que não ama corrução logo após o carnaval Deus deu está provação caso verídico e profundo só não sente neste mundo quem não tiver coração. (...) A mãe D. Severina mais por Bia é conhecida a qual passa muito bem em sua humilde guarida a pobre mãe tão contente ainda estar inocente desta cena referida. 
No entanto, o que se encerraria, em primeira análise, na restrita reprodução de conservadorismos, a partir da perspectiva bakhtiniana, tem rico alargamento. Com efeito, Bakhtin chama atenção para a importância da ruptura entre o oficial e o cômico já na Idade Média. A sátira e o riso constituíam uma forma de libertação popular com relação a instituições e símbolos do poder, especialmente nas festas carnavalescas.

O riso na Idade Média, durante o Renascimento, tornou-se a expressão da consciência nova, livre, crítica e histórica da época. Desfigura, degrada, desvirtua os poderes estabelecidos, na sincronia (a festa e sua ambivalência) e na diacronia (em relação à dimensão histórica). Portanto, o riso liberta e ao libertar concede a consciência social (BAKTHIN, 1993: 64).

Entre os folhetos que tratam de nascimentos monstruosos o apocalipse aparece como marca frequente da religiosidade católica: tais nascimentos anunciariam o fim dos tempos. São bons exemplos disso A menina fenômeno foi moça com 10 meses em Arapiraca, A criança que nasceu com duas cabeças e três braços em Pernambuco, A menina que nasceu em Minas Gerais, com quatro olhos, duas bocas, duas ventas, quatro orelhas e dez dedos em cada mão, entre outros. O Apocalipse previsto seria consequência do mau comportamento humano como indica o trecho do poema que segue:

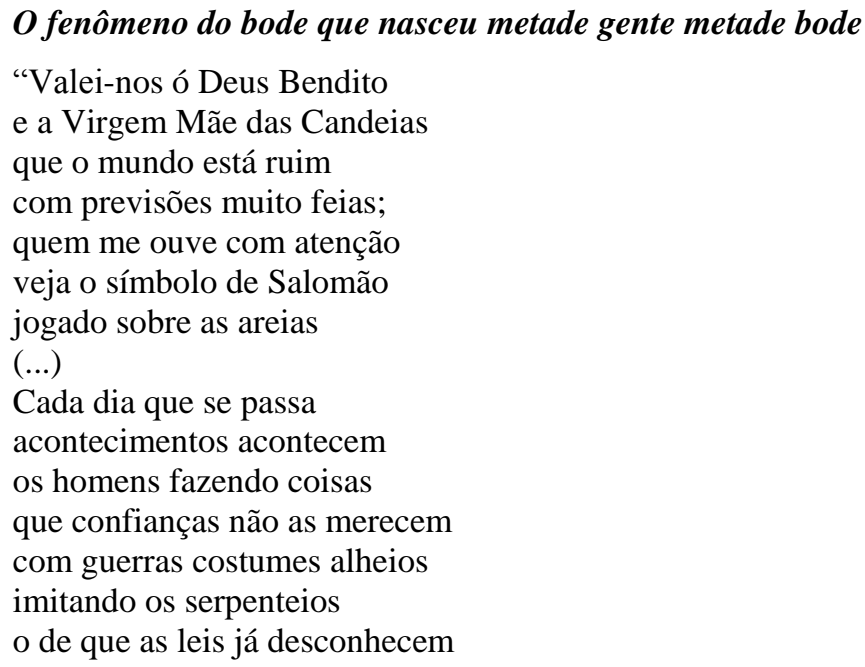

Também são muito comuns as interações com o diabo que têm como consequência o nascimento de crianças que carregariam suas marcas por estarem amaldiçoadas, ou mesmo por serem filhas do próprio com mães pecadoras. Nestes folhetos é comum a mescla de elementos trágicos, cômicos e religiosos. Entre eles estão O bebê Diabo: A história do 
menino que nasceu com 2 chifres e peludo em São Bernardo do Campo, A mulher que deu a luz a um satanás. As proesas de bebê diabo que agora pelo mundo anda a procura do pai e O menino que nasceu com a pintura do cão. Entretanto, para além das marcas características do diabo, alguns dos rebentos descritos neste grupo carregam características animais, como pode ser observado nos casos de Os primogênitos do rapaz que casou com uma porca, ou a porcaria de Romeu, A mulher que deu a luz a uma cobra porque zombou do Bom Jesus da Lapa e $O$ fenômeno do bode que nasceu metade gente metade bode. Neste último vale notar a estratégia retórica do autor, que recorre ao diálogo direto com o leitor ao afirmar a veracidade do caso narrado:

\section{O fenômeno do bode que nasceu metade gente metade bode}

"Eu sempre digo a verdade
pode custar, mas sempre vem
ou mais cedo ou mais tarde
ela aparece, não se retêm
não há força que a detenha
ou na cidade ou na brenha
a verdade é como o bem."

Temos aqui a tentativa de validação do relato com foco na credibilidade do emissor. Do ponto de vista da religiosidade merece destaque o amplo campo de significados que envolvem o bode: um símbolo do paganismo, que foi associado mais tarde à imagem do diabo pela religiosidade cristã. Em algumas tradições o bode representa mesmo o não-cristão.

Nascimentos insólitos quanto no tange transformações bizarras é possível estabelecer paralelos com tipos textuais em diálogo com o cordel. Um dos mais frequentes é a invocação, típica da poesia épica clássica:

\footnotetext{
"O menino que nasceu barbado"

Oh! Santo deus do infinito

Rei dos reis e pai dos pais

Fortificai minha Lira

com as forças divinais

pra eu contar o exemplo

que deu-se agora em Goiás.
}

No trecho do poema que segue temos uma menção à ciência, vista como incapaz de responder a questões de que somente a religiosidade pode dar conta. Também há referências tanto à cultura cristã quanto à cultura grega: 
"O fenômeno do bode que nasceu metade gente metade bode"

"Naquele tempo, Pe. Cicero

soube de uma aberração

mandou Dr. Belém olhar

para tirar a conclusão

e lá na serra do Horto

enterrou um bode morto

sem dar mais satisfação

A Medicina não fala nisso porque ainda não registrou mas o homem sabe que o homem com bicho, também casou

contrariando a natureza mergulha na impureza da vida que procurou

O cruzamento de duas raças diz a ciência: é impossível mas o que se vê na pratica torna isso discutivel por isso chamo atenção necessária e bem cabível

O Centauro e o Minotauro a Sereia e a Medusa são lendas de outras terras mas agora o povo usa com bode que tem de gente se quiser vamos pra frente para ver se não abusa

De acontecimento como esse eu tenho a impressão é o protesto da natureza gritando por atenção é a verdade que aparece é o natural que acontece iluminando a escuridão

Já na Biblia está escrito caso assim, bem parecido quando José lá no Egito por seu pai muito querido os irmãos se censuravam quando eles prevaricavam igual a esse acontecido 


\subsubsection{Transformações}

1. ANDRADE, J. J. A moça que virou cachorra porque deu banana ao padre frei Damião. S.l.: s.n., 19-. (Coleção Ruth Terra).

2. BANDEIRA, Pedro. A mulher que virou cobra por zombar de Frei Damião. Juazeiro do Norte: s.n., 19--.

3. BARROS, João Antonio de. Encontro da crente que virou besta com o crente que virou jumento. Recife: s.n., 19--. (Coleção Ruth Terra).

4. BARROS, João Antonio de. Mensageira do diabo ou a mulher vampiro. Recife: s.n., 19--. (Coleção Ruth Terra).

5. BARROS, João Antonio de. O rapaz que virou cachorro porque zombou do Padre Cícero Romão. Juazeiro do Norte: s.n., 19--.

6. BORGES, José Francisco. A moça que virou jumenta porque falou de top less com Frei Damião. Bezerros: s.n., 19--. (Coleção Gilmar de Carvalho).

7. BORGES, José Francisco. A mulher vampiro e o exemplo das costas nuas. Bezerros: Ed. Prop. José Francisco Borges, 19--. (Coleção Ruth Terra).

8. CAVAlCANTE, Rodolfo Coelho. A moça que bateu na mãe e virou cachorra. Salvador: Ed. Prop. Rodolfo Coelho Cavalcante, 1973. (Acervo Raymond Cantel).

9. CAVALCANTE, Rodolfo Coelho. O filho que levantou falso a mãe e virou bicho. Salvador: Tipografia Ansival,1977. (Acervo Raymond Cantel).

10. CAVAlCANTE, Rodolfo Coelho. O rapaz que bateu na mãe e virou bicho em Feira de Santana. 6. ed. S.1.: Ed. Prop. Rodolfo Coelho Cavalcante, 1967.

11. MAXADO, F. O jumento que virou gente ou o milagre do Frei Damião. Olinda: Casa das Crianças de Olinda, 1979. (Acervo Raymond Cantel).

12. MONTEIRO, José Estácio. Exemplo de um filho que casou com a mãe e virou jumento. Aracaju: Silva, Antonio José da (Folheteiro ambulante), 19--. (Acervo Raymond Cantel).

13. RIBEIRO, Edgley. A mulher que virou Diabo. S.1.: s.n., 1976. (Acervo Raymond Cantel).

14. ROMEU, H. A moça que virou cabra. S.1.: s.n., 19--. (Acervo Raymond Cantel).

15. SANTOS, Alípio Bispo dos. O ateu que virou monstro na noite de São João. S.1.: s.n., 19--.

16. SANTOS, José Martins dos. A moça que virou porca. S.1.: s.n., 19--. (Acervo Raymond Cantel).

17. SILVA, João José da. A moça que virou cobra. Condado: Ed. Prop. João José da Silva, (Acervo Raymond Cantel).

18. SILVA, José Bernardo da. História do rapaz que virou cavalo. Juazeiro do Norte: Tipografia São Francisco, 1958. (Acervo Raymond Cantel).

19. SILVA, José Soares da (Dila). O homem que virou bode. Caruaru: Artfolheto São José de Dila, 19--. (Coleção Ruth Terra). 
20. SILVA, José Soares da (Dila). São Salviano e Satanás. Caruaru: Artefolheto São José, 19--.

21. SOARES, José Francisco. O homem macaco ou o lobisomem do Cabo. Recife: s.n., 19--. (Coleção Ruth Terra).

22. TAVARES, Cavalcante. A filha amaldiçoada. Fortaleza: Secretaria de Cultura e Desporto, 1990. (Coleção Gilmar de Carvalho).

23. VENTURA, Manoel Serafim. O protestante que virou num urubu porque queria matar Frei Damião. S.1.: s.n., 19--. (Coleção Ruth Terra).

24. VITORINO, Vicente. Exemplo da crente que profanou Frei Damião. S.l.: s.n., 19--. (Coleção Ruth Terra).

Nos cordéis apreciados a motivação principal das transformações é o "mau comportamento" do ser transformado. Mulheres infiéis e "assanhadas" surgem alvoroçando as páginas destes folhetos, mas não para por aí. Qualquer confronto direto com a religião católica merece como castigo alguma desagradável transformação. Ataques ou contatos desrespeitosos com as figuras de Padre Cícero e Frei Damião recebem a implacável retaliação divina: a desorganização dos corpos permite o reestabelecimento de uma ordem proposta pela fé cristã. $\mathrm{O}$ ateísmo, ou o protestantismo também não ficam de fora. Frequentemente tais comportamentos são associados à aproximação do fim dos tempos. Em alguns casos, no entanto, o arrependimento proporciona a redenção e o retorno das formas originais do pecador, mas não sem antes muito sofrimento. As formas zoomórficas, glorificadas e cultuadas por antigas sociedades distantes são aqui motivo de vergonha e sofrimento.

\footnotetext{
A mulher que virou cobra

"Não acreditava em Deus

e nem na Virgem Maria

(...)

era uma mulher casada

que traiu seu esposo

e passou a viver jogada

num meretrício seboso

jogou os santos no mato

chamou Jesus de barato

botou gás no retrato

de Frei Damião Poderoso."

A moça que virou porca

"Era muito vaidosa, gostava de cachorrada saía a boca da noite voltava de madrugada e a mãe quando falava ela ficava zangada."
} 


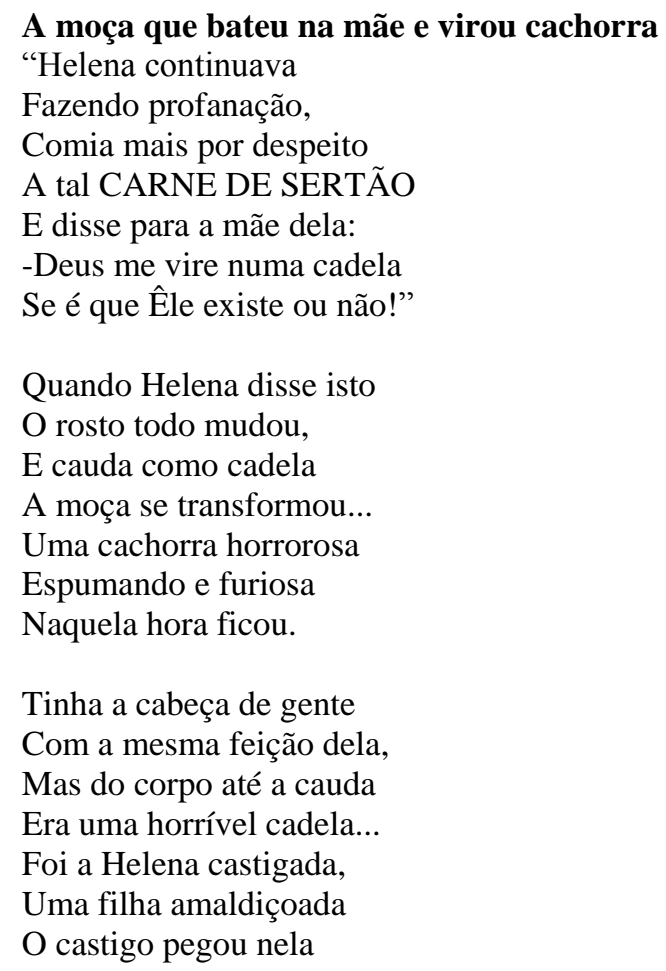

Na primeira amostra o ateísmo é a origem do mal. Neste último excerto é possível identificar características recorrentes entre os cordéis que tematizam a metamorfose: a ideia de exemplo, de punição em terra pelos pecados aqui cometidos. Entre tais produções o diálogo direto com o leitor e a referência a personagens míticos da história universal, ou do imaginário nordestino visam a conquista do receptor:

\footnotetext{
"Caros leitores amigos me prestem muita atenção a algum tempo escrevi estoria de Lampião agora entrei na onda com estoria de assombração

Se você caro leitor teme coisa do outro mundo segure logo a a calça se não vai melar o fundo antes de ler este verso medite logo profundo

Numa vila sertaneja de nome Varzea da Raz aconteceu muita coisa nunca mais lá teve paz segando seus moradores era arte do satanás."
} 
Note-se que é comum que a presença de "celebridades" de toda ordem entrando em cena de modo persuadir o leitor sobre o grande interesse de seu conteúdo. Retornando ao campo da religiosidade merece novamente destaque a figura do bode, como em $\mathrm{O}$ homem que virou bode por zombar de frei Damião São conhecidos boatos em que frei Damião chamava de bode os protestantes.

\subsubsection{Outros:}

1. BARROS, João A. de. História de um peru que falou ou um peru malicioso. S.1.: s.n., 19--. (Coleção Ruth Terra).

2. BARROS, João A. de. O velho caipora. Recife: Editorial Novo Horizonte, 19--. (Coleção Ruth Terra).

3. BARROS, Leandro Gomes. História de Juvenal e o dragão. Juazeiro do Norte: Tipografia São Francisco, 19--.

4. BATISTA, Abraão. A luta de um homem com um lobisomem. Juazeiro do Norte: s.n., 19--.

5. BATISTA, Abraão. Conversa da caapora com o saci pererê. Juazeiro do Norte: s.n., 1992. (Coleção Gilmar de Carvalho).

6. BATISTA, Abraão. O papa-figo Juazeiro do Norte: s.n., 1974.

7. BATISTA, Abraão. O pássaro encantado da gruta do Ubajara. Juazeiro do Norte: s.n., 1978.

8. CALDAS, João Bandeira de. A cobra de dois chifres da lagoa encantada da Timbaúba. S.l.: s.n., 19-. (Coleção Gilmar de Carvalho).

9. CAMPINA, Manoel A. Epaminondas e o monstro da gruta d'água. S.1.: s.n., 19--. (Acervo Raymond Cantel).

10. CARVALHO, José Furtado de. O cavaleiro da lua e o dragão do pôr do sol. S.l.: s.n. 1999. (Coleção Gilmar de Carvalho).

11. CAVALCANTE, Rodolfo Coelho. $O$ boi de sete chifres. Salvador: s.n., 19--. (Acervo Raymond Cantel).

12. CAVALCANTE; Rodolfo Coelho; SANTOS, Alípio B. dos. A mulher sem cabeça que está aparecendo no nordeste. Salvador: s.n., 1972. (Coleção Ruth Terra).

13. FANKA. Padre Cícero e a Vampira. Sociedade dos cordelistas Malditos. Juazeiro do Norte: s.n., 2000. (Coleção Gilmar de Carvalho).

14. GOMES, Paulo de Tarso Bezerra. O rapaz que brigou com o lobisomem. 3. ed. Fortaleza, 1990. (Coleção Gilmar de Carvalho).

15. GONÇALVES, Antônio (Patativa do Assaré). A lâmpada de Aladim. Juazeiro do Norte: Universidade Regional do Cariri (URCA), Associação de Artistas e Amigos da Arte (AMAR), 1989. (Coleção Ruth Terra). 
16. LEITE, José Costa. O cavalo voador ou Juliêta e Custódio. Fortaleza/Ceará: Tupynanquim Editora, 2005. (Coleção Ruth Terra).

17. MELO, Vicente Vitorino. História de Luizinho e o velho feiticeiro. Bezerros: Ed. Prop. José Francisco Borges, 19--.

18. NETO. João Pedro C. Besta do horror. Fortaleza: Ed. do Autor, 2001. (Coleção Gilmar de Carvalho).

19. OLIVEIRA, José Duda de. Homem que tinha fé em Deus e lutou com um dragão. Fortaleza: Manoel Caboclo e Silva, 1979. (Coleção Gilmar de Carvalho).

20. PAULA, Arquimedes de. O valor de Reginaldo e o encanto de Jacira. S.1.: s.n., 19--.

21. PAULINO, Eliseu. O cão da Itaoca, 2010, Coleção Gilmar de Carvalho.

22. RINARÉ, Rouxinol do. O colar de pérolas e a lenda dos vaga-lumes. Fortaleza: Editora Tupynanquim, 2001. (Coleção Gilmar de Carvalho).

23. ROCHA, José Pacheco da. A princesa Rosamunda ou a morte do gigante. São Paulo: Editora Luzeiro, 1974. (Fundação Casa de Ruy Barbosa).

24. RUFINO, H. Rufino. A papa-figo em ação. S.l.: s.n., 19--. (Coleção Ruth Terra).

25. SANTOS, Enéas Tavares dos. O encontro de um feiticeiro com a negra de um peito só. Maceió: Museu Theo Brandão, 1977. (Coleção IEB)

26. SANTOS, Enéas Tavares. A mulher de quatro metros que anda de feira em feira. S.l.: s.n., 19--. (Coleção Ruth Terra).

27. SENA, Joaquim Batista de. História de João Valente e o dragão de três cabeças. Fortaleza: Tipografia Casa dos Horóscopos, 19--. (Acervo Raymond Cantel).

28. SILVA, Expedito F. da. O filho de Juvenal e o dragão vermelho. Rio de Janeiro: s.n., 1978. (Coleção Raymond Cantel).

29. SILVA, José Bernardo. História do boi mandingueiro e o cavalo misterioso. Juazeiro do Norte: Tipografia São Francisco, 1955. (Coleção Ruth Terra).

30. SILVA, José Bernardo. História do boi misterioso. Juazeiro do Norte: Tipografia São Francisco, 19-. (Coleção Ruth Terra).

31. SILVA, José Bernardo. História do pato misterioso. Juazeiro do Norte: Tipografia São Francisco, 1955. (Coleção Ruth Terra).

32. SILVA, José Soares da (Dila). Camões e o rei mágico. Caruaru: Folhetaria São José de Vandecila Silva, 19--. (Acervo Raymond Cantel).

33. SILVA, Minelvino Francisco da. A mulher de sete metros que apareceu em Itabuna - Estado da Bahia. Itabuna: s.n., 1968. (Coleção Ruth Terra).

34. SILVA, Minelvino Francisco da. A prisão do gigante da montanha assombrosa. Juazeiro do Norte: José Bernardo da Silva, 1974. (Acervo Raymond Cantel).

35. SILVA, Minelvino Francisco da. História do bicho de sete cabeças. São Paulo: Editora Luzeiro. (Acervo Raymond Cantel).

36. SILVA, Minelvino Francisco da. História do gigante da montanha assombrosa. Juazeiro: Filhos de José Bernardo da Silva, 1974. (Acervo Raymond Cantel). 
37. SILVA, Minelvino Francisco da. Os martírios de três irmãs e a tragédia de um pássaro encantado. S.1.: s.n., 19--. (Coleção Ruth Terra).

38. SOARES, José. Negra de um peito só. Olinda: Casa das Crianças de Olinda, 19--.

39. SOARES, José. O caranguejo de Várzea Nova. S.l.: s.n., 19--. (Coleção Ruth Terra).

40. SOARES, José. O fenômeno dos fenômenos: o rio de São Francisco secando. S.1.: s.n., 19--. (Coleção Ruth Terra).

41. SOARES, José; CAMPOS, Francisco Souza. Abelhas, morcegos e grilos sugando a humanidade. Recife: s.n., 19--. (Coleção Ruth Terra).

42. VIANA, Antônio Klévisson. A história de João e o pé de feijão. Fortaleza: Editora Tupynanquim, 2000. (Coleção Gilmar de Carvalho).

43. VIANA, Arievaldo; PAULINO, Pedro Paulo. A caveira do ET encontrada em Quixadá. Ceará: Tupynanquim, 2005. (Coleção Gilmar de Carvalho).

44. LEITE, José Costa. A vaca misteriosa que falou profetizando.

Este agrupamento envolve temas bastante variados: aparição de bichos anormais, gigantes, dragões, seres fantásticos como o pássaro encantado, o cavalo alado, o peru falante, a caipora etc.

No caso do Pássaro encantado da gruta do Ubajara temos referência ao ano bissexto 1968. Na trama, o corajoso Mustafá encontra um pássaro encantado que havia sido a própria Iemanjá (na descrição aproximada à própria Vênus - descrição de beleza europeizada), filha de um importante cacique (cultura indígena/ afro-brasileira?). Mustafá (que é judeu) vence um monstro semelhante a um macaco (Mustafá chega a ser comparado ao deus Apolo da cultura clássica grega) e salva a princesa Iemanjá. Ao longo do poema uma "pitonisa rara" estabelece paralelo com as sacerdotisas de Apolo.

Em O valor de Reginaldo e o encanto de Jacira o herói luta contra uma cobra mágica em um ambiente de fábula com muitos seres encantados.

Já o papafigo, ilustrado com chifres na capa do cordel tem a habilidade do disfarce.

Aqui, como em cordéis portugueses, há a presença de intrigantes histórias de reinos distantes: 


\section{Epaminondas e a gruta d'agua}

"Em setecentos e quinze

Num territorio Hungriano

Quando a Austria e a Hungria

Dominava um Soberano

Desenrolou-se um segrêdo

Naquele imperio tirano" [...]

"No imperio desse principe

Apareceu um misterio

Assombrando toda gente

E devorando o imperio

Que para toda creatura

Tornou-se em caso serio

Com dez leguas de distancia

Daquele grande reinado

Apareceu um Dragão

Misterioso e encantado

No terreno Gruta d'Agua

Era por ele habitado

Não tinha uma pessôa

Que passasse ali por perto

Que o monstro farejasse

Para não morrer por certo

Por causa disso tornou-se

Ali o maior deserto

Era um monstro horroroso

Horrivel, sanguinolento

Com dois metros de altura

E doze de comprimento

A cabeça com dez pontas

E orelhas como jumento"

Mas nem tudo acontece em tempos e espaços desconhecidos: Fenômenos de aspecto mais regionais também têm espaço entre os seres fantásticos e acontecimentos estranhos: No próximo poema, moça ambiciosa herda fazenda do pai. Acaba resolvendo vender tudo, pois preferia lidar com o dinheiro:

\section{Boi de sete chifres}

Faltava vender um Boi

Sendo este de encomenda,

Pela causa do desgôsto

Vieram as rugas do rosto

Para sua trite senda. 
Era um Boi de sete chifres

Que na Boa Fé pastava,

O comprador deste Boi

Boa quantia lhe dava,

Porém depois de pegado,

Disse Lúcia:- está fechado,

Dizendo que o entregava.

Mandou chamar os Vaqueiros:

Agostinho Potifar,

Chico Lopes, Né Caçote

Para o dito Boi pegar,

Esses não deram roteiro

No imenso taboleiro

Que vivia ele a pastar.

Lúcia desta vez gastou

Grande soma de dinheiro

E ainda prometeu

Publicamente ao vaqueiro

Que o "Sete Chifres" pegasse

Que garantia casar-se

Se fosse um rapaz solteiro. (...)

Lúcia acaba gastando todo seu dinheiro em menos de um mês, mas oferece seus últimos "cem contos" àquele que conseguir pegar o boi fugitivo.
Dou aquele que pegar
Esse Boi de Sete Chifres
E se o Diabo o laçar
Me trazendo na Fazenda
Eu serei a sua prenda
Pode comigo casar.
Satanás ouvindo isto
Soltou grande gargalhada
E disse consigo mesmo:
-Esta alma está laçada...
Amanhã eu mostro á ela
Que o vil orgulho dela
Para mim não vale nada.

O diabo então se aproveita da situação, mas Lúcia depois de uma visão e um aviso, arrepende-se de sua soberba e desfaz o negócio com Satanás, identificado como Burburinho.
Desapareceu o Boi
E o tal de "BURBURINHO
Lúcia muito arrependida
Procurou outro caminho,
Tratou de unir-se ao pobre
E a falsa vida nobre
Deixou-a por seu carinho. 
O boi mandingueiro aparece em diversos folhetos como uma fera indomável de feições fantásticas. Ninguém consegue capturá-lo, parece estar associado ao Diabo. Um fazendeiro promete muito dinheiro pela sua captura, além da mão de sua filha (relação com histórias em que o rei promete coisas pra quem capturar o dragão?). Um jovem herda um cavalo misterioso de seu pai ancião, que lhe faz algumas recomendações: não emprestar nem o cavalo nem a sela, pois assim poderia derrubar até Satanás. A história não se encerra, prometendo um próximo volume. Em A vaca misteriosa que falou profetizando, no momento de ser ordenhada, a vaca Maroca surpreende a todos falando. Ela critica o comportamento humano e anuncia o fim dos tempos. Uma oração ao Padre Cícero é deixada ao final da mensagem. Bovinos, são recorrentemente associados aos mistérios de deus e do diabo.

A associação entre monstros e o apocalipse perpassou os três agrupamentos da amostragem. Segue um exemplo:

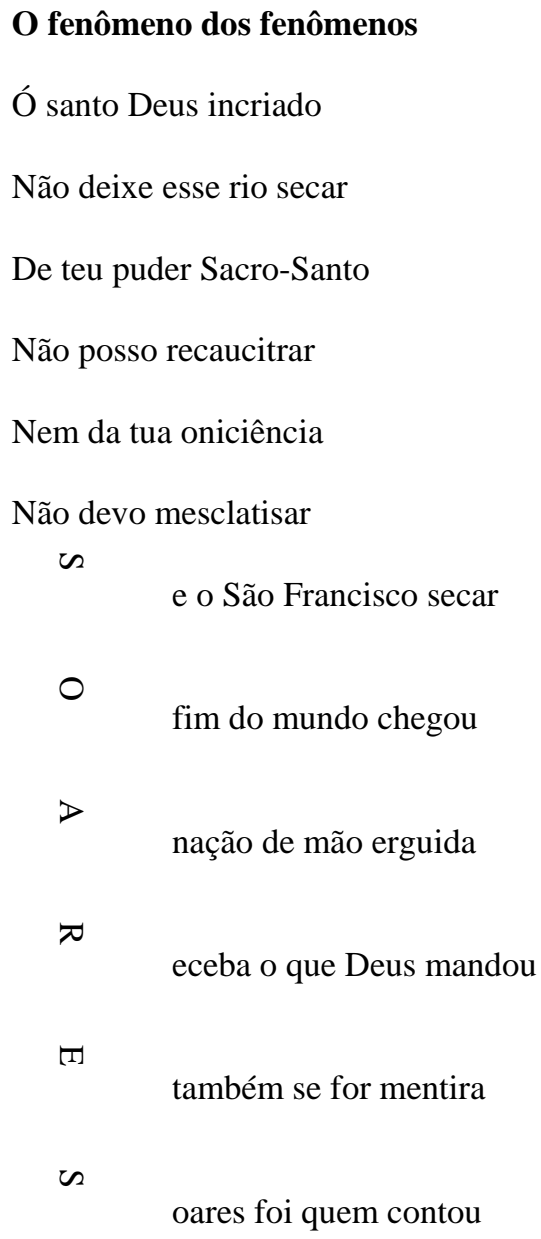


No mesmo poema: a ciência incapaz de explicar fenômenos:

\author{
Na América um ciêntista \\ Fez uma roda quadrada \\ Coiza que estava prevista \\ $\mathrm{Na}$ escritura Sagrada \\ No mensageiro da fé \\ E na missão abreviada
}

Alguns folhetos fundem curiosas aparições associando-as à religiosidade em detrimento de um insuficiente conhecimento da ciência acerca de tais casos:

\author{
Caranguejo de Várzea Nova \\ (...) \\ O segredo da natureza \\ Não há quem possa entender. \\ (...) \\ Na Paraíba do Norte \\ Na capital João Pessoa \\ Município Várzea Nova \\ A terra de gente boa \\ Apareceu um fenonimo \\ Peixando a ciência a tôa.
}

Severino pesca um caranguejo grande e diferente em tudo, narra o poema:

No casco do caranguejo

O emblema de uma cruz

O pescador, cria o caranguejo e passa a exibí-lo à multidão que paga para vê-lo por alguns segundos. Ninguém sabe ao certo o que ele significa, se bom, ou se mal, mas para muitos ele passa a ser visto como um milagre.

Matinhos e casca de frutas

Com que o caranguejo Sá

se alimenta, são tirados

pros doentes tomar chá.

Dizem ser uma relinquia

Mandada por Jeová. 
Eis que a religiosidade cristã aparece para organizar a realidade "desorganizada" do tal caranguejo ofertando explicações divinas para o aparecimento da estranha criatura. Em síntese, mais uma vez a desorganização do monstro serve à organização do meio que o circunda. 


\section{Capítulo 3}

\subsection{A xilogravura no cordel brasileiro: aproximações e afastamentos}

A arte da xilogravura foi praticada no Brasil, a partir do século XIX, supostamente por influência do colonizador, ganhando espaço em veículos de comunicação de grande circulação para época. O pesquisador Jeová Franklin explora esta hipótese a seguir:

A técnica da xilogravura chegou ao Brasil no período colonial. Foi usada na estampagem de tecidos e papéis de parede, na produção de cartas de baralho e na edição de imagens e textos sacros. Em 1815 estreou na literatura em História Verdadeira da Princesa Mangalona (...). Os primeiros autores das matrizes em madeira eram os xilógrafos vindos da Europa.(...). No Rio Grande do Norte , O Mossoroense, um dos três jornais mais antigos em circulação no Brasil (...) ilustrou notícias e publicidade com gravuras talhadas pelo diretor e proprietário, João da Escócia, no período de 1902 até 1909, ano em que faleceu (FRANKLIN, 2007: 13).

Everardo Ramos, no entanto, problematiza essa chegada ao afirmar que não há comprovação documental sobre quando e onde se iniciou a prática da xilogravura no Brasil. Relatos de viajantes indicam como as populações indígenas já faziam uso de matrizes de madeira para imprimir, com tinta, desenhos nos corpos e, por vezes, para estampar peças de indumentária. Embora esta seja uma prática comum a mais de duas dezenas de tribos indígenas, os registros históricos da prática de xilogravura remontam apenas ao período colonial (RAMOS, 2010).

De acordo com Gilmar de Carvalho (2001), a xilogravura foi introduzida no Brasil em 1808. Somente após quase duas décadas é que se encontram registros da sua chegada ao Ceará, em Fortaleza, por volta de 1824, e na região do Cariri, em 1855. Veio de Recife junto com a imprensa e o seu uso estava, inicialmente, voltado para ilustrações de papéis comerciais e vinhetas para jornais e livros. No século XX surgiu a ilustração comercial em pequenos anúncios e, a partir da década de 1930 a xilogravura passou a predominar nas capas de folhetos de cordel. A necessidade editorial exigia pressa nas impressões e nas vendas, e o alto custo e a demora na fabricação dos clichês de metal, que no início do século XX ainda não eram comercializados na região do Cariri, tornava necessário o deslocamento a Recife 
ou Fortaleza para adquiri-los. Tendo em vista a dificuldade na obtenção de clichês, passouse a encomendar xilogravuras a artistas com o objetivo de ilustrar capas de folhetos de cordel. Este formato, no entanto, parecia agradar mais a intelectuais e a turistas que ao público em geral, que preferia os clichês de metal (DE PAULA; VENEROSO, 2012).

A zincogravura foi o tipo de ilustração preferido do público tradicional de folhetos, contribuindo muito para o enorme sucesso da literatura de cordel. Já a xilogravura era utilizada principalmente nas cidades do interior, como Juazeiro do Norte, no Ceará, onde gráficas rudimentares não permitiam praticar técnicas mais elaboradas, como era o caso no Recife. A este respeito, Franklin afirma que a valorização acadêmica da gravura popular criou, entre intelectuais, a lenda da fidelidade entre os dois meios expressivos da cultura do povo: a literatura de cordel e a xilogravura. Por isso, outras formas de ilustração, como o desenho, a fotografia, os postais, eram consideradas fugas ao comportamento padrão. A ideia da xilogravura não prosperava diante do público tradicional de folheto popular (...). Era comum o comentário maldoso contra alguém: "fulano é feio como capa de cordel" (FRANKLIN, 2007: 14).

A partir da década de 1960 foi que a xilogravura começou a se destacar e ganhar status. Intelectuais começaram a produzir álbuns de gravuras, o que fez com que a xilogravura ganhasse proporções internacionais.

Em resenha publicada na Revista do IEB, Peter Burke afirma que uma ampla literatura secundária sobre folhetos surge com o declínio do gênero nos anos 1960, ilustrando, assim, o que Michel de Certeau chamou de "beleza do morto". Contudo, evocando Everardo Ramos, na perspectiva do historiador da arte, pouca atenção foi dada às ilustrações dos folhetos. Este autor também enxerga que, para o grande público (composto não por turistas e intelectuais), as ilustrações modernas parecem mais autênticas, ou pelo menos mais "populares" que as arcaicas. É também comum que as imagens muitas vezes sejam adaptações de outras mais antigas, frequentemente recicladas e empregadas por diversos editores em textos diversos. Por conta desta tendência à individuação e a outros fatores, as ilustrações xilogravadas tornam-se um gênero independente, vendido para colecionadores e museus. Seguindo a lógica da circularidade, o autor segue levantando questões sobre o tema: Artistas brasileiros anônimos teriam tido familiaridade com a obra de artistas europeus? A arte contemporânea pode ter influenciado nossas xilogravuras? (BURKE, 2007). Este fenômeno, assim como o 
crescente interesse da classe média pelos folhetos de cordel, se insere no que tem sido chamado de "invenção do Nordeste” (ALBUQUERQUE JÚNIOR, 2001).

Everardo Ramos problematiza também a intervenção do mundo letrado neste universo, ao passo em que ela não se limita a transformar a gravura popular em categoria artística, mas também define esta categoria, pela própria maneira como a estabelece. De fato, as diversas ações de promoção e valorização da gravura popular - artigos na imprensa, exposições, publicação de álbum e constituição de coleção - têm como objeto apenas um tipo de obra: a xilogravura dos folhetos de cordel. Técnica e função constituem, portanto, noções identificadoras da nova categoria artística, guiando as atitudes e as reflexões dos intelectuais da época. Com o passar do tempo, tais noções iriam inclusive cristalizar-se, fazendo com que, nos dias de hoje, a expressão "gravura popular" se confundisse frequentemente com a palavra "xilogravura" e com a categoria "ilustração de folheto de cordel", como se todas fossem sinônimos. Confrontando esta definição com o estudo das próprias obras, percebe-se, no entanto, que ela não traduz completamente a realidade dos fatos, tal como eles se apresentavam aos artistas e intelectuais que começaram a se interessar pela gravura popular. Se a apologia da técnica artesanal e das formas rústicas explica o sucesso de uma certa categoria de obras (a xilogravura estilizada) e o esquecimento de outras (a zincogravura e a xilogravura "naturalista"), é necessário explicar também as razões dessa própria apologia, a fim de se compreender o processo de legitimação artística da gravura popular em toda sua complexidade.

Para Ramos (2007), as iniciativas que têm por objeto a gravura popular manifestam o que caracteriza as concepções e atitudes de tipo folclórico: a admiração pelas coisas do passado, principalmente pelas técnicas artesanais, cujo desaparecimento é frequentemente anunciado, em razão do progresso técnico-industrial; a ideia de que o mundo letrado pode e até deve - evitar esse desaparecimento, tirando as obras ameaçadas de seu ambiente natural para integrá-las no circuito erudito de coleções, exposições e publicações; a preferência dada a certas categorias de obras, em detrimento de outras, em função de critérios preestabelecidos que sempre associam o "popular" ao manual, simples, primitivo, rústico, antinaturalista; a certeza, enfim, que o criador popular, sendo autodidata, é necessariamente ingênuo, e que seu anonimato é um valor positivo, ao contrário da afirmação individual expressa numa assinatura. 
Nesse mesmo artigo produzido por Ramos, Ariano Suassuna, pai do movimento armorial, é evocado: ele, em um primeiro momento, associa a gravura popular à arte contemporânea e, em particular, à obra de artistas como Picasso, Gauguin, Chagall, Rousseau e Modigliani. Para ele, o ponto de contato entre estas produções seria o primitivismo inerente à arte popular, e incorporado pela arte erudita do século XX, bem como uma "comunidade de intenções" entre artistas de culturas diferentes, no momento da criação. A perspectiva muda completamente, no entanto, num texto do final dos anos 1960, quando Ariano Suassuna, já famoso, inspirando-se na tradição ibérica e na literatura de cordel - também considerada uma "reminiscência medieval" - para criar um teatro "tipicamente nordestino", prefere associar a ausência de perspectiva à arte medieval que à arte moderna. "Esta questão resume toda a dimensão folclórica e regionalista do processo de promoção e legitimação artística da gravura popular" (RAMOS, 2010: 40).

A nova atitude de Ariano Suassuna mostra que ele, assim como outros intelectuais de sua geração, foi condicionado a encarar a obra de arte popular - principalmente a realizada no Nordeste - apenas como uma relíquia de uma idade remota, de uma época mítica e idealizada, berço de uma "pureza original” que teria se perdido em seguida, com os progressos da razão, do capital e da máquina - com a Modernidade, enfim. Daí a preferência pela xilogravura artesanal, rústica e primitiva, e o desprezo pelas outras categorias de ilustração de cordel, a zincogravura e a xilogravura refinada, que não se encaixam nas noções estabelecidas para "popular" e "nordestino", tanto por questões técnicas como estéticas (RAMOS, 2010: 45).

Assim, retomamos uma questão que perpassou toda a dissertação: ao tratar do cordel brasileiro, estamos a tratar de um objeto artístico representante de uma cultura genuinamente "pura", livre de diálogos e de intercâmbios? Assim como Everardo Ramos, acreditamos que não. A própria seleção de capas de folhetos que virá na próxima seção procurará, ainda que de maneira incipiente, revelar um pouco sobre isso. 


\subsection{Considerações acerca das capas de alguns folhetos:}

\subsubsection{Nascimentos}

\subsubsection{Capas "realistas"}

Se por um lado diz-se que a partir dos anos de 1960 o cordel passou a ter como público alvo colecionadores e intelectuais, mais afeitos às xilogravuras que às ilustrações coloridas ou reproduções de fotografias frequentemente inspiradas nas telas dos cinemas, por outro, temos aqui uma amostra de capas que optaram pela imagem pouco nítida, e talvez mesmo alterada de imagens fotográficas cujos motivos são bebês extraordinários. Tais folhetos parecem buscar afastamento da atmosfera de comicidade muitas vezes pressuposta pela xilogravura, ou esperada, quase que como um estigma, para este tipo de suporte. A falta de nitidez, ou mesmo o enquadramento, não permitem examinar com precisão os traços de insolidez pressupostos pelos títulos dos folhetos, mas o uso deste tipo de imagem parece conferir maior verossimilhança aos fenômenos, numa espécie de aproximação ao modelo informativo que apresenta provas, ainda que discutíveis.

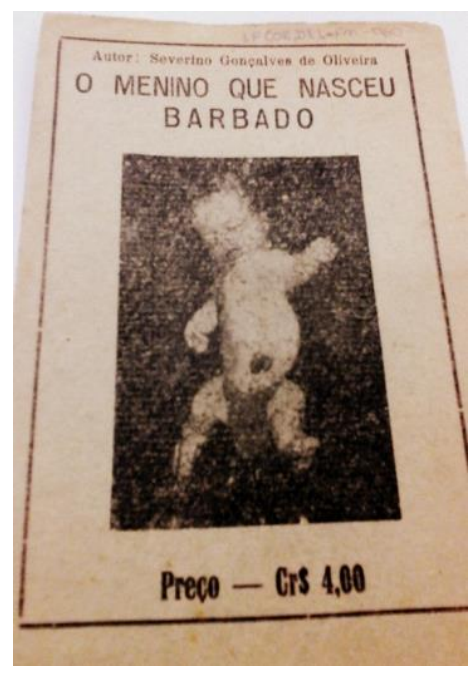

Figura 5 O menino que nasceu barbado, de Severino Gonçalves de Oliveira

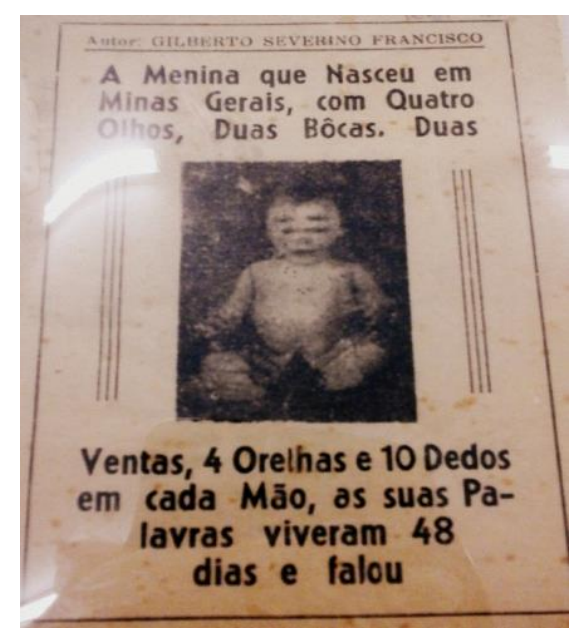

Figura 6 A menina que nasceu em Minas Gerais, com quatro olhos, duas bôcas, duas ventas, 4 orelhas e 10 dedos em cada mão, as suas palavras viveram 48 dias e falou, de Gilberto Severino Francisco.

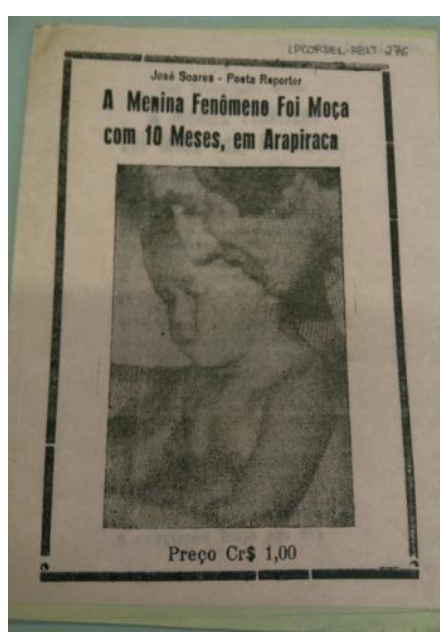

Figura 7 A menina fenômeno foi moça com 10 meses, em Arapiraca, de José Soares. 


\subsubsection{Xilogravura - com foco no bebê}

Na xilogravura com foco no bebê insólito repete-se um dos artifícios mencionados no caso do uso da imagem fotográfica: Exemplares como "O Menino Monstro", de Abraão Batista apostam na imprecisão da imagem, que chegaria mesmo a intensificar a atmosfera de terror. Outros apostam em estratégias como a xilogravura de Jeronimo na capa de "A mulher que deu a luz a Satanás", conferindo-lhe o humor grotesco, mais afinado com o próprio poema.

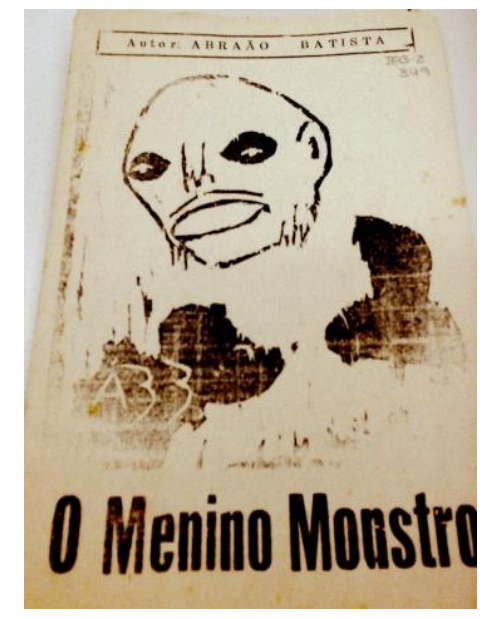

Figura 80 menino monstro, de Abrã̃o Batista.

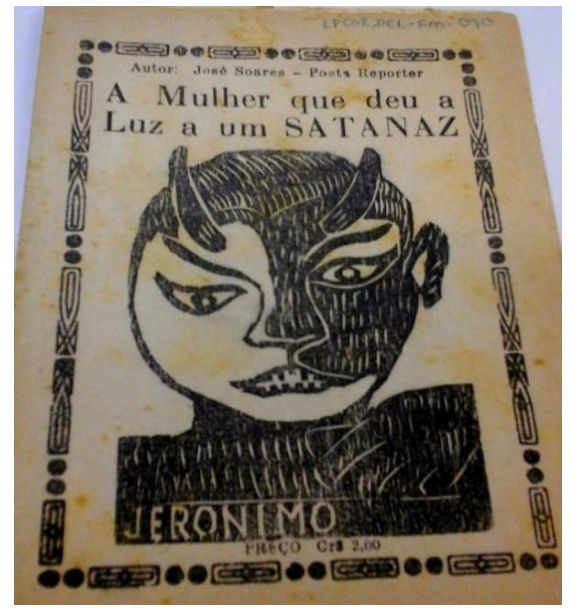

Figura 9 A mulher que deu a luz a um satanaz, Jeronimo.

\subsubsection{Xilogravura - sem foco no bebê}

Folhetos com tais características parecem assumir a dificuldade intrínseca ao tratamento direto da imagem de bebês fantásticos e optam por figurar não as crianças, mas personagens relacionados à narrativa. Por vezes, como no caso de $\mathrm{O}$ menino que nasceu com a cabeça nas costas, chega a ser difícil mesmo o estabelecimento de relações entre capa e conteúdo. 


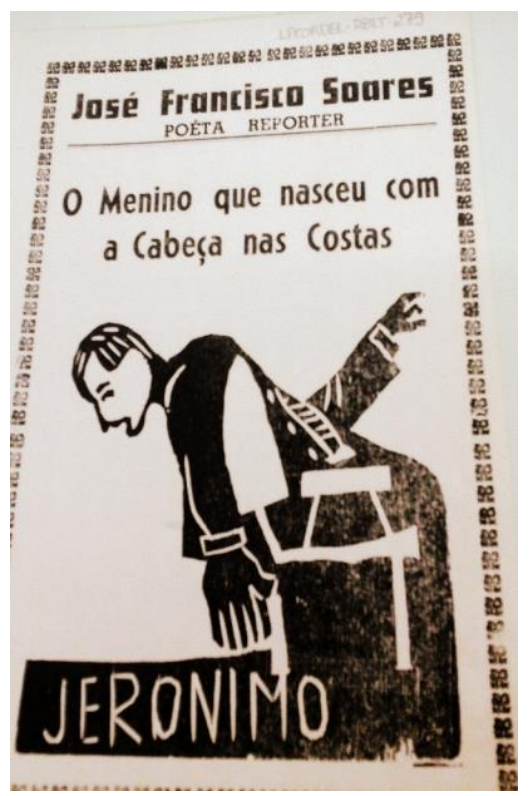

Figura 10 O menino que nasceu com a cabeça nas constas, Jeronimo

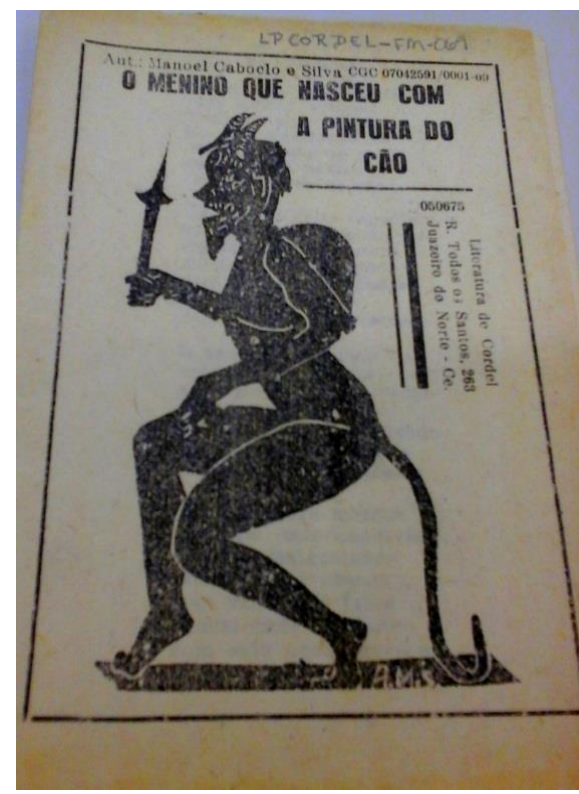

Figura 11 o menino que nasceu com a pintura do cão, de Manoela Caboblo e Silva.

\subsubsection{Transformações}

.Aqui a xilogravura se revela opção que contribiu ao caráter cômico de obras que têm preocupação com a moralização dos hábitos conforme a religuão católica. 


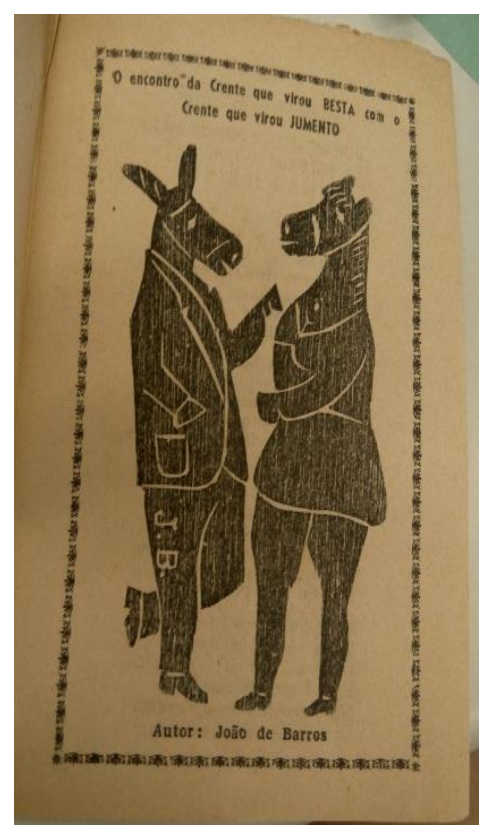

Figura 12 A moça que virou jumenta porque falou de top less com Frei Damião, de José Francisco Borges.

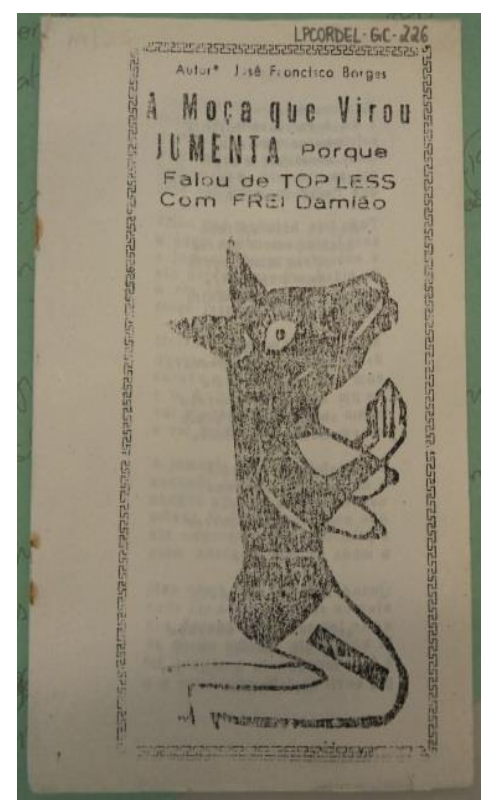

Figura $13 O$ encontro da crente que virou besta com o crente que virou jumento, de João de Barros.

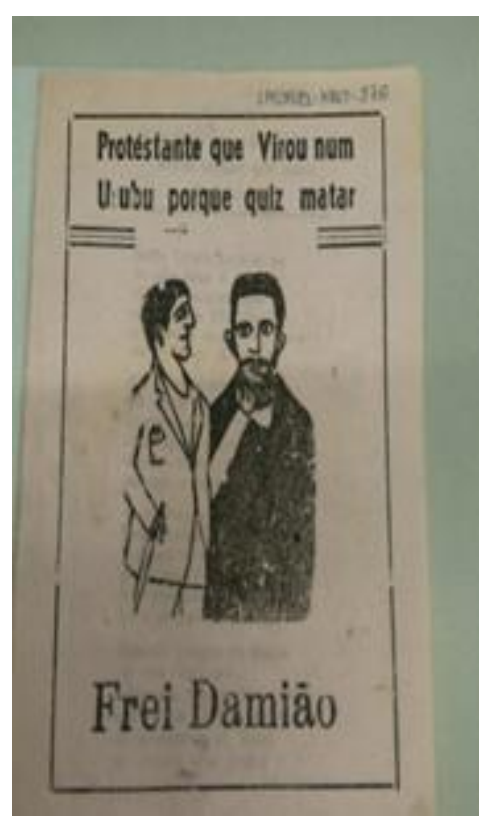

Figura 14 Protestante que virou num urubu porque quiz matar Frei Damião, de Manoel Serafim Ventura.

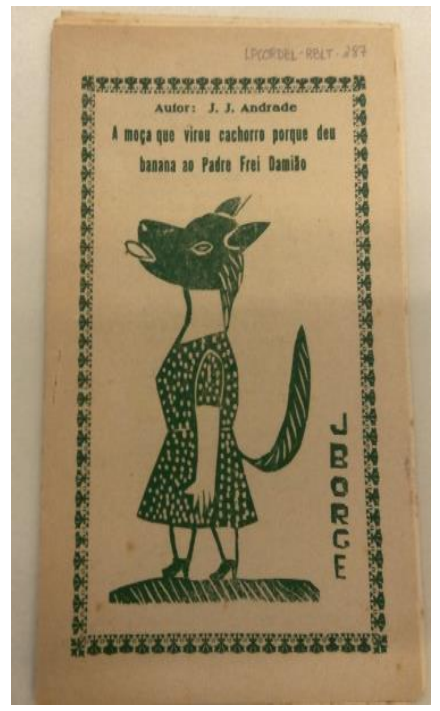

Figura 15 A moça que virou cachorro porque deu banana ao padre Frei Damião, de J. J. Andrade.

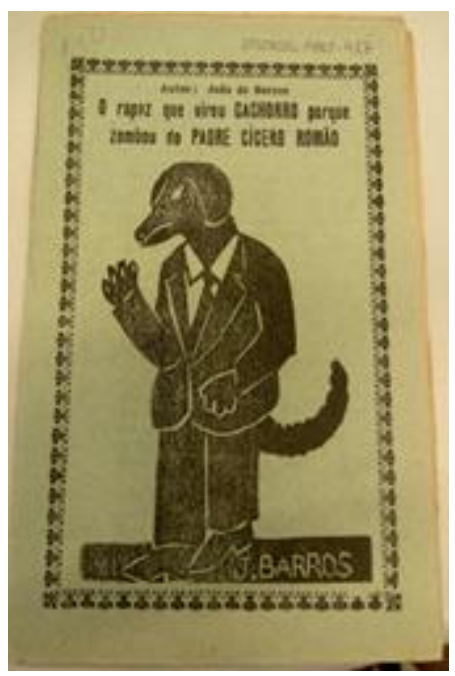

Figura 16 O rapaz que virou cachorro poque zombou do padre Cícero Romão, de João de Barros.

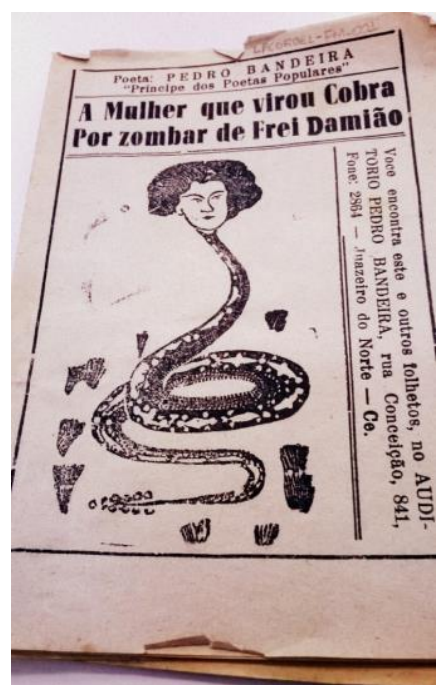

Figura 17 A mulher que virou cobra por zombar de Frei Damião, de Pedro Bandeira. 


\subsubsection{Outros}

\subsubsection{Referências à literatura universal}

São bastante comuns as capas que fazem referência a criaturas fantásticas da literatura universal: vampiras, gênios, cobras gigantes, centauros. Neste agrupamento parecem imperar técnicas diversas: xilogravura, zincografia, ilustrações etc. Algumas capas chegam a revelar paralelos que ficam pouco claros quando nos apoiamos exclusivamente nos textos. Possivelmente a capa não intencionasse ilustrar o texto, mas chamar a atenção do público apelando para temáticas associadas. É o caso de $\mathrm{O}$ homem macaco, ou o lobisomem do cabo. A primeira hipótese interpretativa da associação entre capa e título leva as telas do cinema: O clássico estadunidense mais que revisitado teve versões para o cinema em 1918, 1932, 195 e, 1981. Considerando que as culturas nordestinas não estiveram alheias ao contato com a cultura pop estadunidense, a associação imagética parece bastante plausível. No entanto, se quisermos regredir no tempo, outras referências podem ser associadas à esta mesma capa: $\mathrm{O}$ caso da hipertricose, doença que reveste de vasta pelugem o corpo de seu portador e lhe confere aparência selvagem. Há registros de antigos relatos que relacionam a doença ao mito do lobisomem:

Gonsalvus was born in Teneriffe in 1556. Raised at the court of Henry II of France, he also spent time at the court of Margaret of Parma, together with his wife and children. The artist of the Ambras portraits is unknown. The giant and dwarf in another painting in the same collection have been tentatively identified with Giovanni Bona, court giant of Ferdinand II, and the dwarf Thomerle 20 The painting illustrates one of the display strategies common to many collections, which exaggerated the effect of their contents by surprising juxtapositions. (DASTON; PARK, 1998, p. 194).

Também chama atenção a presença de um centauro, criatura cuja parte superior é figura típica da mitologia grega, com cabeça, braços e dorso de um ser humano e com corpo e pernas de cavalo em um diálogo direto com a capa, mas não com o conteúdo de História de Luizinho e o velho feiticeiro. 


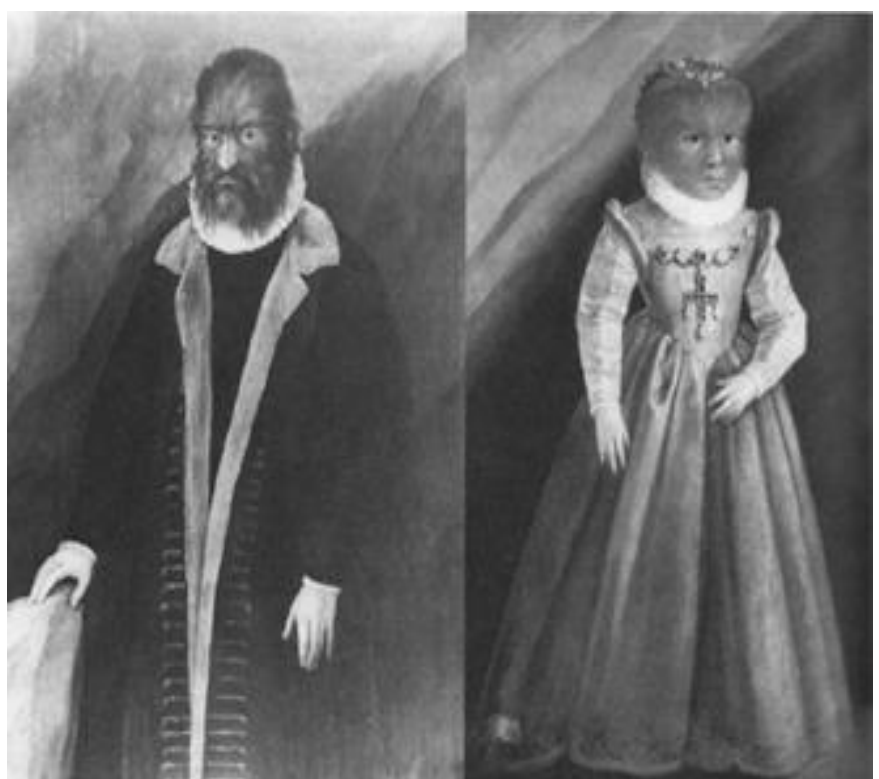

Figura 18 Retratos dos monstros de Schloss Ambras. À esquerda, Petrus Gonçalvus, à direita, sua filha. (Fonte: Museu da História da Arte, Viena.) Rothschild.)

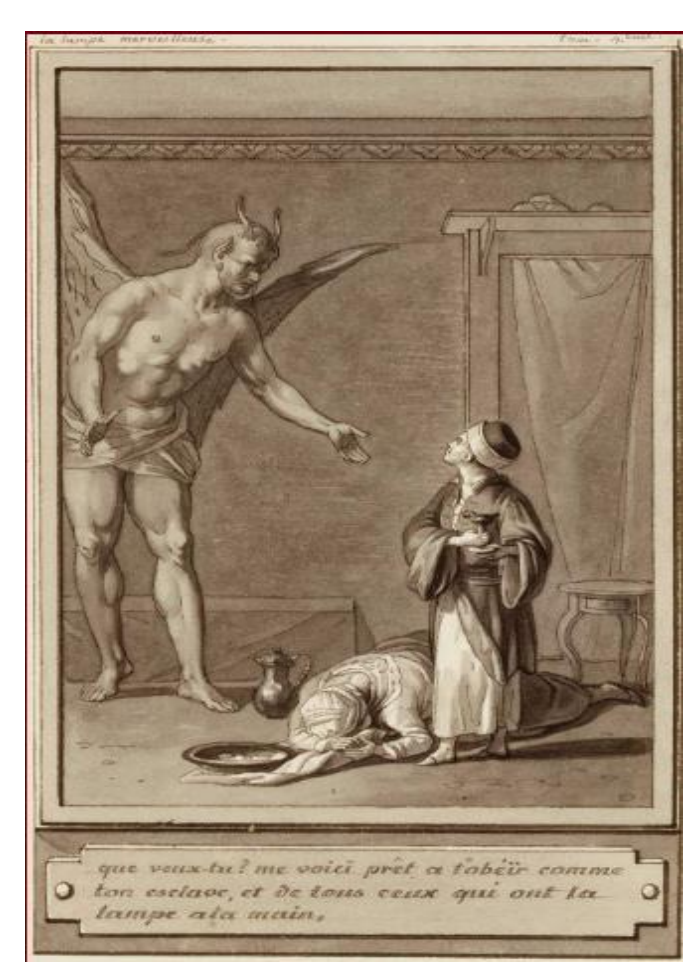

Figura 20 Dessins pour le Cabinet des fées Marillier, Clément-Pierre (1740-1808). (Fonte: Biblioteca Nacional de Paris, Acervo

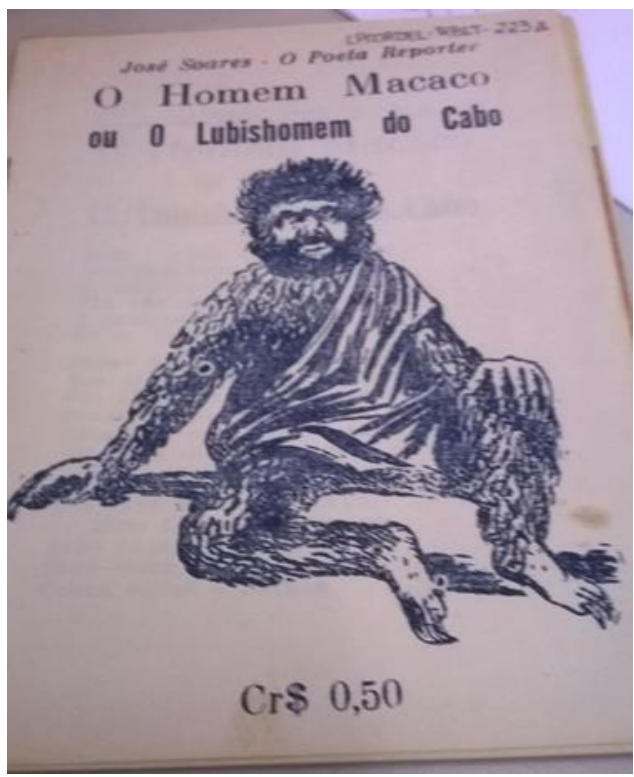

Figura 19 O homem macaco ou o lubisomem do cabo, de José Soares.

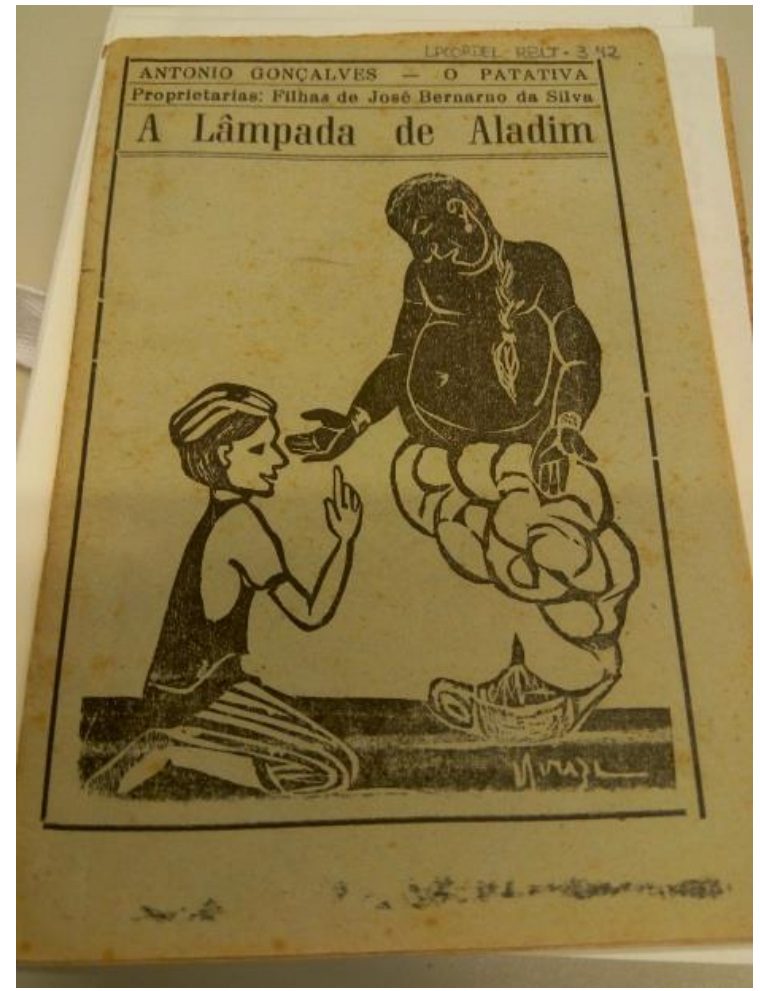

Figura 21 A lâmpada de Aladim, de Antonio Gonçalves (Patativa do Assaré). 


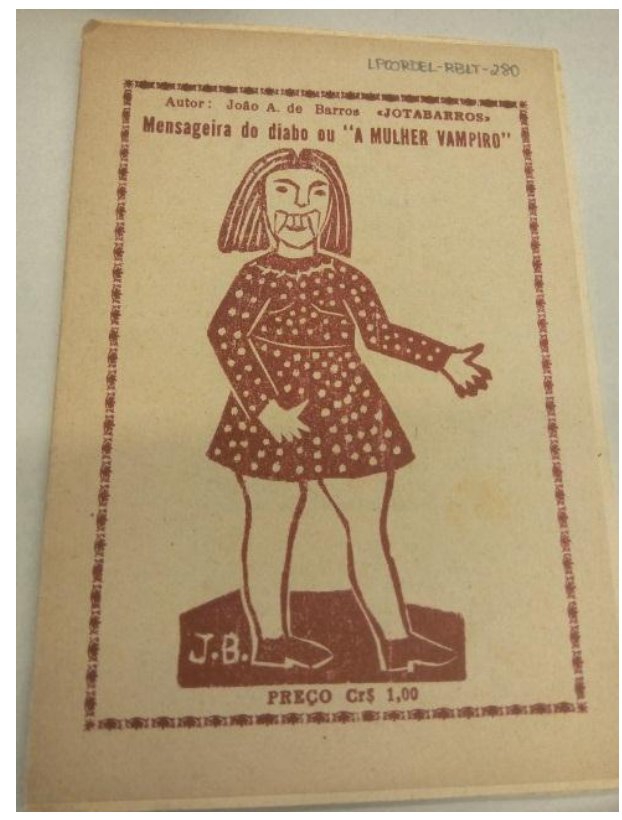

Figura 22 Mensageira do diabo ou " $a$ mulher vampiro", de João de Barros.

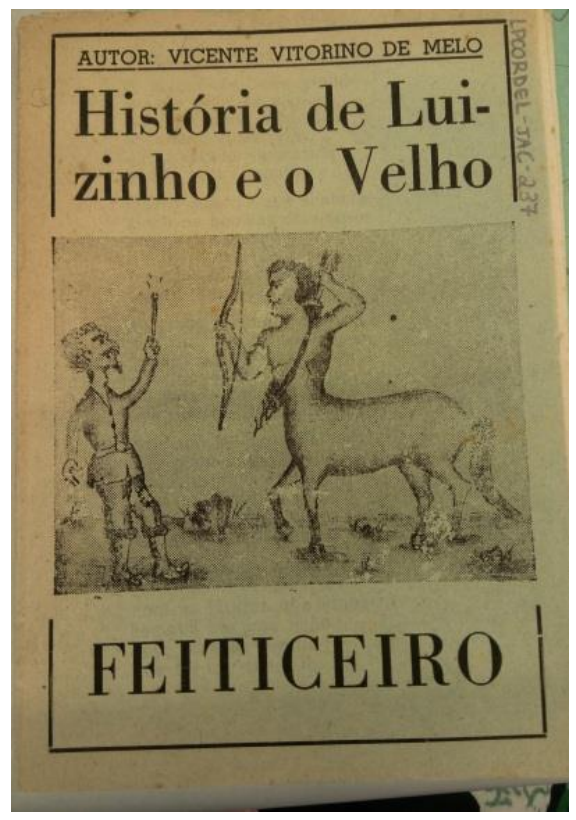

Figura 23 História de Luizinho e o velho feiticeiro, de Vicente Vitorino de Melo.

\subsubsection{Dragões}

As capas que tratam de dragões explicitam claros paralelos com estórias típicas da tradição europeia. Vale o destaque para Raquel e a fera Encantada. A técnica utilizada na confecção desta capa parece ser a da zincografia e valoriza traços mais característicos de tradições do oriente, sugerindo que no interior do folheto estaria por vir uma história de mistérios ligados a um povo distante. 


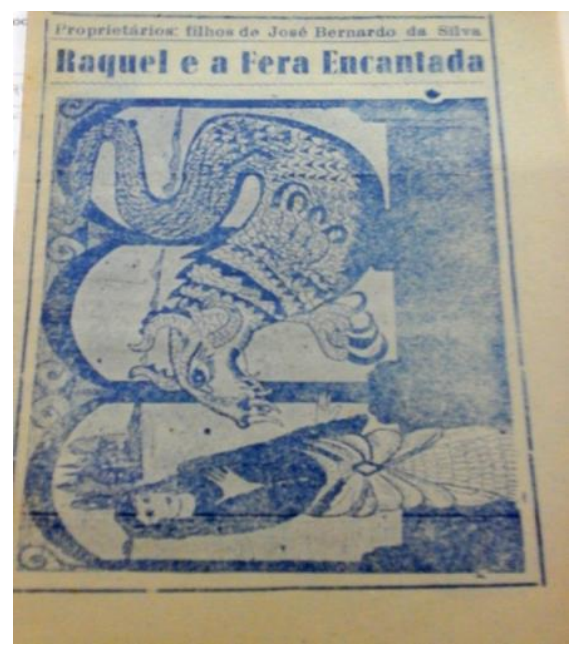

Figura 24 Raquel e a fera encantada, de José Bernardo da Silva.

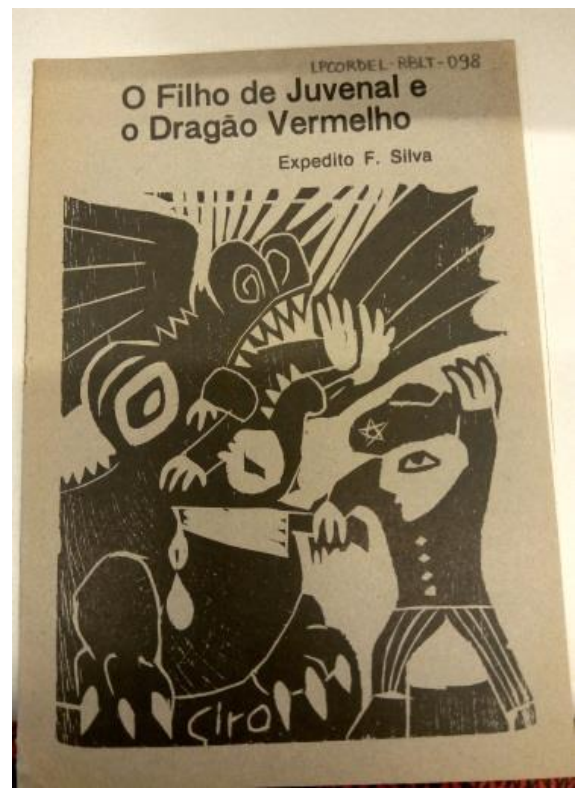

Figura 26 O filho de Juvenal e o dragão vermelho, de Expedito F. Silva.

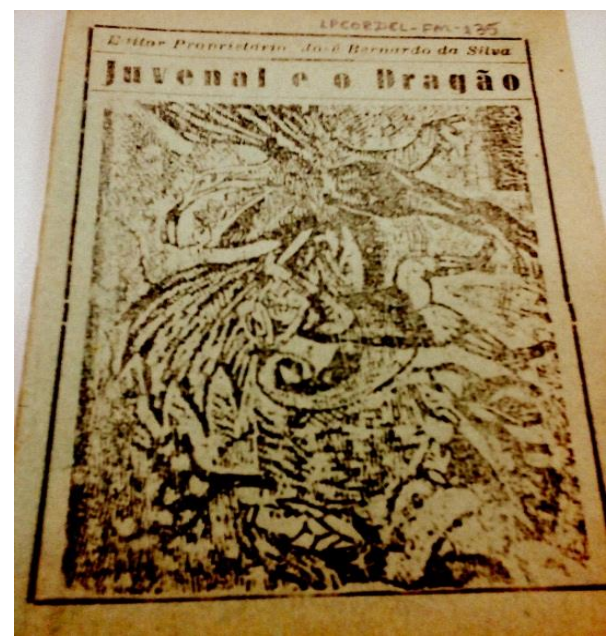

Figura 25 Juvenal e o dragão, de José Bernardo da Silva.

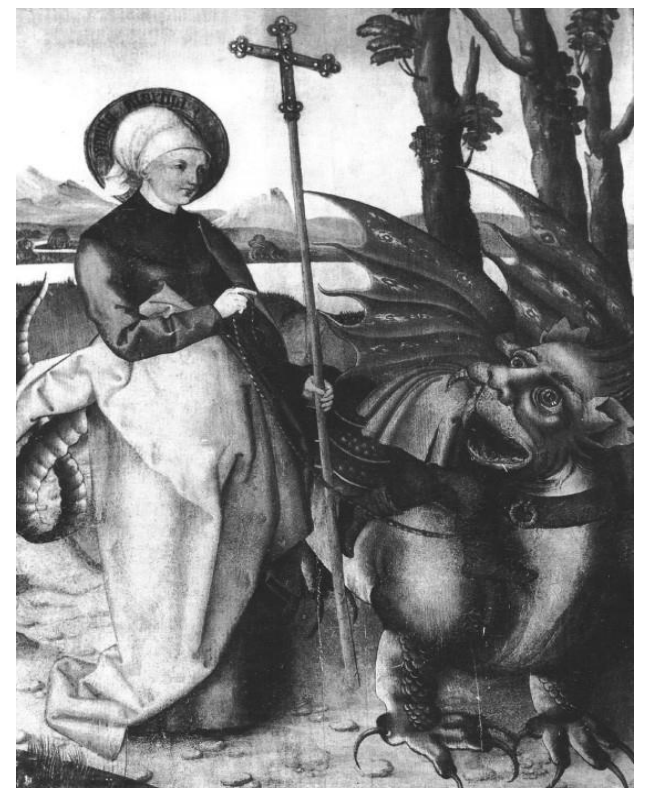

Figura 27 Imagem do altar de Marta presente na Igreja St. Lorenz, em Nuremberg (Alemanha), mostrando a santa com uma Tarasca. (Fonte: <http://de.wikipedia.org/w iki/Bild:MarthaundDrache.jpg>. Acesso em 18.07.2015.) 


\section{Outros seres assustadores ou impressionantes}

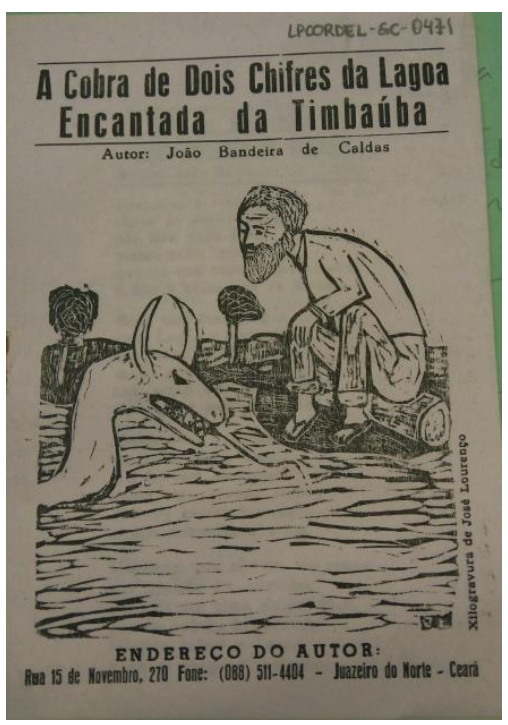

Figura 28 Mensageira do diabo ou "a mulher vampiro", de João de Barros.

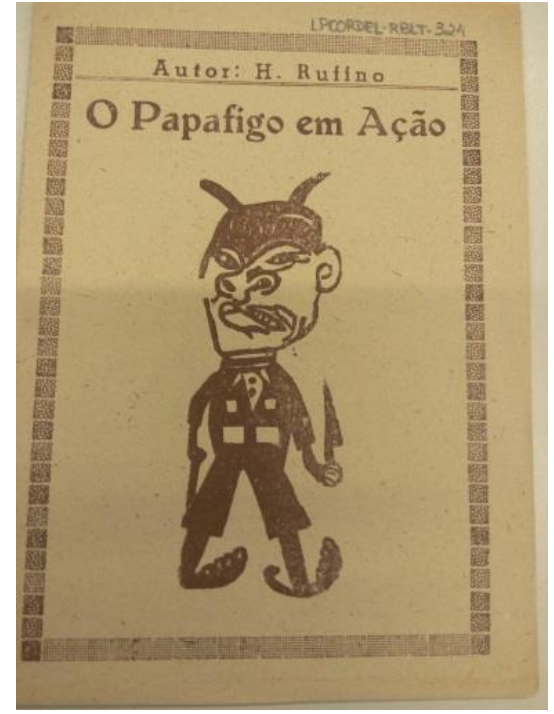

Figura 29 O papafigo em ação, de $H$. Rufino

\subsubsection{Seres Maravilhosos}

Neste caso há grande variação de técnicas, tratamentos e possivelmente de públicosalvo. As referências culturais também são variadas e tem inspiração em folclores do nordeste, do oriente, mas também da cultura europeia. Vale notar as semelhanças entre as capas, ainda que apropriadas de diferentes técnicas, de Cavalo encantado e $O$ cavalo voador - ou Julieta e Custódio. 


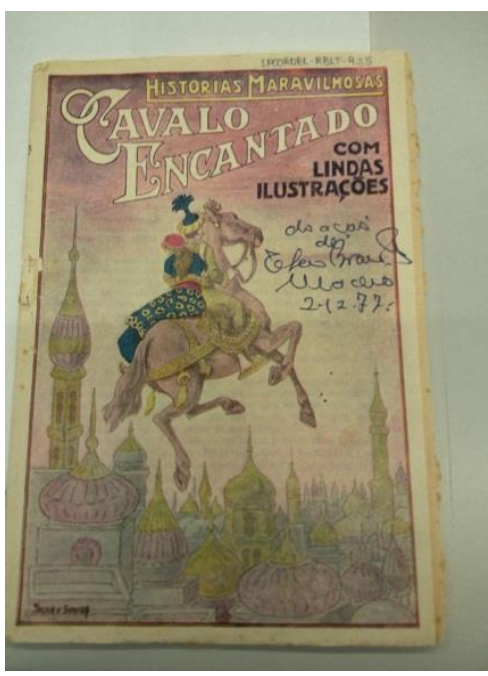

Figura 30 Cavalo encantado, coleção Ruth Terra

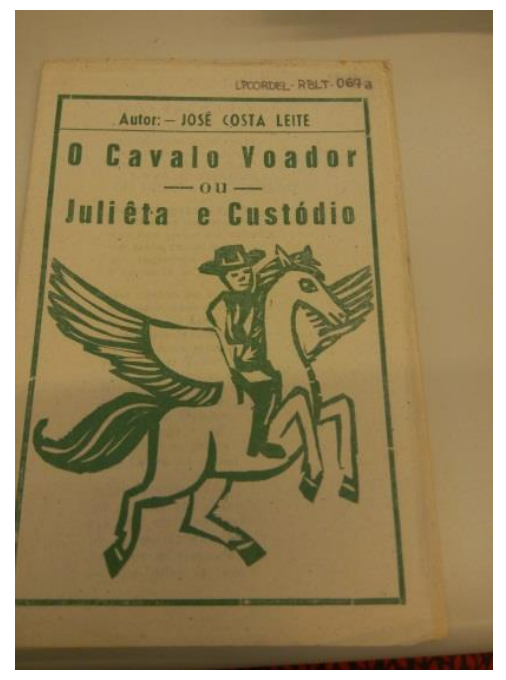

Figura 31 o cavalo voador ou Juliêta e Custódio, de José Costa Leite.

\subsubsection{Gigantes}

Nos cordéis listados, o fenômeno tem contornos de exagero e opta pela xilogravura, que parece pretender feições de maior regionalidade para o fenômeno narrado. Há também exemplares com gigantes que remontam o imaginário da literatura europeia, como João e o pé de feijão, que optou por uso de capa ilustrada e colorida. 

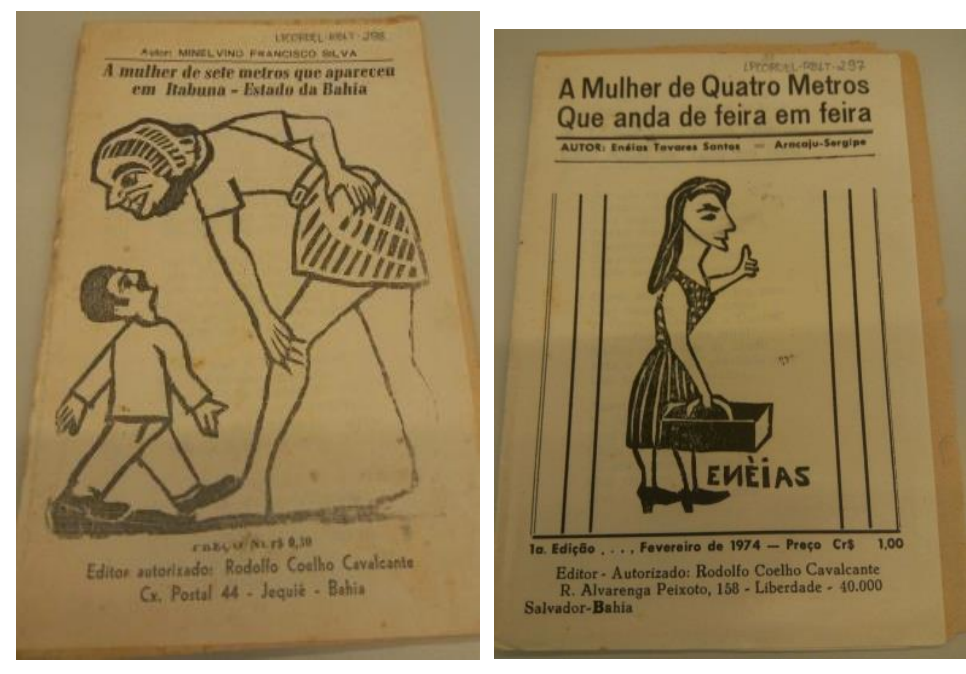

Figura 32 A mulher de sete metros que apareceu em Itabuna - Estado da Bahia, de Minelvino Francisco Silva.
Figura 33 A mulher de quatro metros que anda de feira em feira, de Rodolfo Coelho Cavalcante.

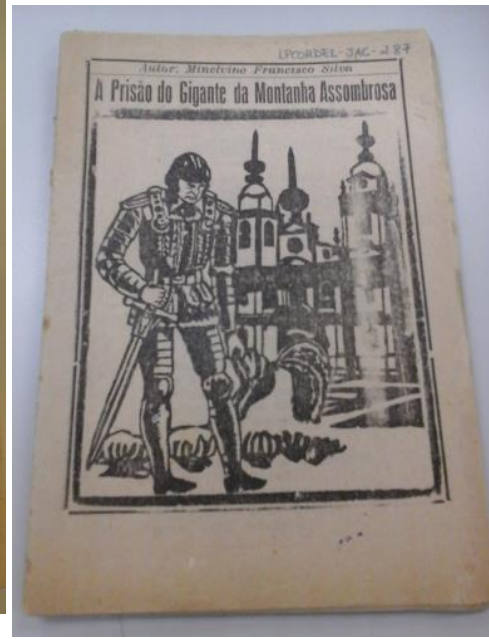

Figura 34 A prisão do gigante da montanha assombrosa, de Minelvino Francisco Silva. 


\section{Conclusão}

Saberes sobre monstros discutidos tanto pela ciência e pela teologia - ora associados à metafísica, ora compreendidos como desvios da natureza -, quanto aqueles difundidos por meios associados à ideia de menor prestígio e credibilidade - a exemplo dos canards franceses, ou dos colportages que se espalharam pela Europa - revelam cruzamentos que diluem a noção de culturas "eruditas" e "populares" que de alguma forma não se imprimam uma na outra. Por muito tempo, relatos do "público leigo" sobre a aparição de monstros alimentaram a "alta ciência", ao passo que também essa prestigiada ciência alimentou o imaginário de artesãos e de contadores de histórias que, por vezes, mesmo anônimos, encantavam o povo.

Em meados do século XVI, por exemplo, a estética do grotesco se manifestou na obra La vie de Gargantua et de Pantagruel de François Rabelais. Eis um caso típico da circularidade de saberes envolvendo seres monstruosos impressa na literatura: pautada por um tipo de humor considerado inadequado para a elite europeia e taxada como imprópria pelo poder eclesiástico a obra encontra suas fontes tanto na cultura do povo quanto na cultura erudita. Mais que isso: nessa pentalogia de romances, como bom conhecedor do grego antigo, Rabelais passou a inventar palavras a partir dele, algumas das quais passaram a fazer parte do vocabulário francês.

Não resta dúvida quanto aos movimentos circulares que caracterizaram a produção de saberes na Europa de séculos atrás, mas como se comporta essa circularidade quando testada em outros tempos e espaços? Retomando a discussão etimológica acerca da palavra 'monstro' (mostrare), presente no Capítulo 1 desta dissertação, nos perguntamos: o que o tratamento dado a esses seres na literatura de cordel brasileira produzida no século XX pode nos mostrar? Retomando ainda discussões do Capítulo 2: quantos paralelos não podem ser estabelecidos com o tipo de trânsitos culturais que levaram Carlo Ginzburg a especular sobre as relações entre a obra do poeta Ovídio e a do pintor Ticiano, que levaram Natalie Zemon Davis a investigar relações entre Os provérbios de Salomão e as respostas de Marcolf? A tentativa compreender tais trânsitos, especialmente no recorte temático selecionado para o corpus desta pesquisa, revela que muitos são os paralelos possíveis. Passemos em revista, portanto, o que constatamos a respeito dos monstros nos folhetos de cordel brasileiros. 
A pesquisa verificou que a aparição de seres grotescos e monstruosos no cordel brasileiro é marcada principalmente por casos relacionados a nascimentos ou transformações insólitas, atrelados a fortes marcas da religiosidade católica e a repetidas menções aos sinais do fim dos tempos. Há significativo número de exemplares mais localizados no campo da religiosidade, ou ainda, da simples curiosidade pelo incompreensível. A abordagem predominantemente humorística de elementos sacros, tanto nas imagens quanto nos poemas, propõe certa resistência a uma compreensão dura de religião, transgredindo-a. Os valores da razão científica também são desorganizados diante das aparições monstruosas, que oscilam entre a tentativa de verossimilhança e uma irresistível comicidade, operações que resultam em ironia no sentido mais rigoroso do termo, e que não prescindem de formulações textuais que nos remetem ao engenho ou à agudeza.

As aparições insólitas mais frequentes envolvem estranhos nascimentos, seres próprios à literatura universal, como dragões; gigantes; monstros assustadores em suas mais variadas formas, associados a localidades por vezes bastante distantes, por vezes o espaço natural do poeta; seres fantásticos, como aves dotadas de poderes especiais ou mesmo cavalos alados; zoomorfias diversas e criaturas mais diretamente associadas às lendas nacionais, como o homem do saco (Papafigo), ou figurações em torno da imagem "folclórica" do boi. É patente o cruzamento de variadas referências no corpus analisado. Vale reiterar, aqui, que nossa opção por um recorte temático no lugar do tradicional estudo da literatura de cordel por ciclos procurou realçar a presença de tamanha variedade e intercâmbio de referências.

As análises dos poemas evidenciaram a presença marcante do catolicismo - ofensas à fé católica, o "mal nascimento" como fruto do "pecado feminino", a crença nos fenômenos como sinais do apocalipse, além da interação com o próprio diabo, ao fenômeno da zoomorfia, a possíveis relações explícitas com outros modelos literários - presença de artifícios retóricos clássicos, utilização de recursos próprios da poesia épica, tais como a "invocação" ou o mesmo a analogia a obras consagradas da literatura universal.

Muitos observadores do cordel quiseram ver, em poetas com os mais diversos repertórios calcados na cultura letrada ou na simples vivência, algum tipo de retorno à medievalidade ou afirmação de tradições, extraindo disso teses sobre o funcionamento da "cultura popular": seu conservadorismo ou sua ação de resistência, seu arcaísmo ou sua inovação, e, sobretudo, sua autenticidade. Isto fez, e segue fazendo, parte do longo processo 
de "interpretação do Brasil" que concedeu ao Nordeste um lugar de honra em tudo que nos seria mais atávico, para o bem ou para o mal.

Outros estudiosos, por sua vez, procurando entender o grau de agência dos poetas diante de seus públicos e dentro das malhas da economia da edição dos folhetos, ressaltaram o cordel como espaço de experimentação formal, bricolagem e também como produto editorial vendável, sem hierarquias de "autenticidade". Os folhetos utilizados nesta pesquisa nos direcionam muito mais a este tipo de interpretação da cultura do cordel. Nossos monstros não estão permanentemente associados à medievalidade ou a algum folclore local - eles podem ecoar motivos de outros tempos e espaços, relacionar-se com a "cultura pop", com a comunicação de massa, até com internet. Mesmo as inegáveis marcas da piedade católica, realmente "observáveis" nas tradições do Nordeste, não esgotam de modo algum todo o nosso corpus. Talvez caiba sempre enfatizar as ressignificações dos conteúdos pela via da sátira um grotesco intencional e não acidental -, atendendo ao evidente interesse comercial pelo cômico.

É pois no que diz respeito ao uso da imagem nos cordéis que é notória sua importância editorial como propaganda do que será vendido, já que os folhetos movimentam economia em torno deles. Neste sentido, seres híbridos chegam a povoar até maior número de capas que de narrativas. A xilogravura se sobressai como estética mais usada para tais fins, ainda que divida espaço com a fotografia que, por vezes, surge para conferir certa verossimilhança ao que é contado. São comuns os casos em que o poeta é também o artista da xilogravura da capa, produzindo imagens para serem vendidas em paralelo aos cordéis. Aparentemente, o público com maior interesse na xilogravura nordestina, seja como capa de cordéis, seja como obra de arte, é composto por intelectuais, turistas, colecionadores e indivíduos especialmente interessados em culturas locais.

Quanto ao fenômeno recente a que se convencionou chamar "cultura nordestina", temos muito ainda a refletir sobre a materialidade e a construção de discursos e de imaginários embebidos em ideologias dominantes (ALBUQUERQUE JUNIOR, 2001).

Ainda assim, a ideia de cultura popular calcada sobre um recorte social (a cultura do "povo", dos "humildes", dos "autênticos") permanece fascinando um sem-número de pesquisadores, mesmo que ela acabe sendo descrita em termos tão flexíveis que não a definam de fato. 
Toda cultura viva não é nem menos nem mais que "reinventar, recriar e ressignificar" saberes e práticas. O cordel brasileiro, queiram chamá-lo de popular ou não, de autêntico ou inventado, faz precisamente essa incessante reinvenção, recriação e ressignificação de formas, temas e motivos literários e imagéticos, como esperamos ter esboçado neste trabalho, imperfeitamente, no caso do tratamento que dão ao insólito. 


\section{Bibliografia}

\subsection{Referências}

ABREU, Márcia. Histórias de Cordéis e Folhetos. Campinas: Mercado de Letras/Associação de Leitura do Brasil; São Paulo: Fapesp, 1999.

ALBUQUERQUE JÚNIOR, Durval Muniz de. A invenção do Nordeste e outras artes. São Paulo: Cortez; Recife: Massangana, 2001.

ALMEIDA, R. C. O grotesco medieval - Hyeronimus Bosch e as cantigas de maldizer portuguesas. In: Revista Cultura E Extensão - Usp, São Paulo v. 3, p. 57-63, mai. 2010.

AMARAL, Amadeu. Tradições Populares. São Paulo: Hucitec, 1976.

AMORIM, Maria Adelina. Viagem e mirabilia: monstros, espantos e prodígios. In: CRISTÓVÃO, Fernando (Coord.). Condicionantes Culturais da Literatura de Viagens: Estudos e Bibliografias. Lisboa: Edições Cosmos, 1999.

ARISTÓTELES. Analíticos Posteriores. In: Órganon. Tradução: Edson Bini. São Paulo: Edipro, 2005.

DE PAULA, Francisco Sebastião; VENEROSO, Maria do Carmo Freitas. A gravura de ilustração no cordel e a gravura de arte no ceará: diferenças e similaridades. In: . A trajetória da xilogravura no Ceará, nos seus diferentes segmentos: de ilustração, comercial, artística e no campo ampliado. Tese (Doutorado em Artes). Universidade Federal de Minas Gerais, Minas $2012 . \quad$ Gerais, Disponível http://www.anpap.org.br/anais/2012/pdf/simposio10/francisco_de_paula_e_maria_do_carm os_veneroso.pdf. Acesso em: 05.01.2016.

ARISTÓTELES. Retórica. Tradução: Edson Bini. 1. ed. São Paulo: Edipro, 2011. 
AUERBACH, E. Mimesis: a representação da realidade na literatura ocidental. 5. ed. São Paulo: Perspectiva, 2007.

BAKHTIN, Mikhail Mikhailovich. Cultura popular na Idade Média e no Renascimento: o contexto de François Rabelais. Tradução: Yara Frateschi Vieira. 7. ed. São Paulo: Hucitec, 2010.

BASQUES JÚNIOR, Messias Moreira. As Verdades da Mentira: Ensaio Etnográfico de Folhetos de Cordel. São Carlos: USFCar, 2012.

BATISTA, Francisco das Chagas. Cantadores e poetas populares. 2. ed. João Pessoa: UFPB, 1997.

BATISTA, Sebastião Nunes. Antologia da Literatura de Cordel. Natal: Fundação José Augusto, 1977.

BENJAMIN, Roberto Emerson Câmara. Breve notícias de antecedentes franceses e ingleses da literatura de cordel nordestino. Tempo Universitário, Natal, v. 6, n. 1, p. 169-188, jan./jun. 1980.

BENJAMIN, Roberto Emerson Câmara. Literatura de cordel: expressão literária popular. Bando, Natal, ano 3, 1952. p. 228-243. Separata.

BENJAMIN, Walter. Origem do drama barroco alemão. Tradução: Sérgio Paulo Rouanet. São Paulo: Brasiliense, 1984. p. 193.

BENVENISTE, Émile. O vocabulário das instituições indo-europeias. Tradução: Denise Bottmann e Elionora Bottmann. Campinas: EDUNICAMP, 1995, v. II.

BEZERRA, Amilcar Almeida. Movimento armorial x tropicalismo: dilemas brasileiros sobre a questão nacional na cultura contemporânea. In: V ENECULT - ENCONTRO DE ESTUDOS MULTIDISCIPLINARES EM CULTURA. UFBA. Salvador, Bahia. 2009.

BLACK, Jeremy A.; GREEN, Anthony. Gods, Demons and Symbols of Ancient Mesopotamia. Ilustrações de Tessa Richards. London: The British Museum Press, 1992. 
BORGES, Jorge Luis; GUERRERO, Margarita. El libro de los seres imaginarios. Barcelona: Emecé, 1990.

BOUZA, Fernando. Locos, enanos y hombres de placer en la corte de los Austrias. Madrid: Ediciones Temas de Hoy, 1991.

BURKE, Peter. Gravura popular brasileira. Resenha de RAMOS, Everardo. Du marché au marchand. La gravure populaire brésilienne. Gravelines: Musée du Dessin et de l'Estampe Originale, 2005. Tradução do inglês de João Adolfo Hansen. Revista do IEB, n. 44, pp. 243246, 2007.

BURKE, Peter. Cultura Popular na Idade Moderna. Tradução: Denise Bottmann. São Paulo: Companhia das Letras/Companhia de Bolso, 1999.

BURKE, Peter. O que é história cultural? Tradução: Sérgio Goes de Paula. Rio de Janeiro: Jorge Zahar Editor, 2005.

CAMPOS JÚNIOR et al. Nada mais que a verdade: a extraordinária história do jornal Notícias Populares. São Paulo: Summus Editorial, 2011.

CANCLINI, Nestor Garcia. Culturas Híbridas. São Paulo: Edusp, 2000.

CARVALHO, Gilmar de. Desenho gráfico popular. São Paulo: IEB/USP, 2000. (Coleção Cadernos do IEB.)

CARVALHO, Gilmar de. Xilogravura: doze escritos na madeira. Fortaleza: Expressão Gráfica, 2001.

CASCUDO, Luis da Câmara. Vaqueiros e cantadores. Belo Horizonte: Itatiaia/ São Paulo: Edusp, 1984.

CAVALCANTI, Maria Laura Viveiros de Castro. Cultura popular e sensibilidade romântica. Revista Brasileira de Ciências Sociais, v. 19, n. 54, p. 57-79, fev. 2004.

CAVIGNAC, Julie. A literatura de cordel no Nordeste do Brasil. Da história escrita ao relato oral. Natal: EDUFRN, 2006. 
CAVIGNAC, Julie. A literatura de cordel no Nordeste do Brasil: da história escrita ao relato oral. Natal: Ed. da UFRN, 2006.

CERTEAU, M. de; JULIA, D; REVEL, J. A beleza do morto: o conceito de cultura popular. In: . A invenção da sociedade. Tradução: Vanda Anastácio. Lisboa: Difel, 1989.

CESARINY, Mario. Horta de literatura de cordel. Lisboa: Assírio \& Alvim, 2004.

CHARTIER, Roger. A História Cultural entre Práticas e Representações. Tradução: Maria Manuela Galhardo. Rio de Janeiro: Bertrand Brasil, 1990.

CHARTIER, Roger. Cultura popular: revisitando um conceito historiográfico. Estudos Históricos. Rio de Janeiro, v. 8, p. 179-192, 1995.

CHARTIER, Roger. Le monde comme representation In: Annales. Économies, Sociétés, Civilisations, ano 44, n. 6, 1989.p. 1505-1520.

COSTA, Palmira Fontes da. O Corpo Insólito: Dissertações Sobre Monstros no Portugal do Século XVIII. Porto: Porto Editora, 2005.

CUCHE, Denys. A noção de Cultura nas Ciências Sociais. Bauru: Edusc, 1999.

CUNHA, Antônio Geraldo. Dicionário etimológico da língua portuguesa. Rio de Janeiro: Lexikon Editora, 2010.

CURRAN, Mark. História do Brasil em cordel. São Paulo: Edusp, 2001.

DARNTON, Robert. O grande massacre de gatos e outros episódios da história cultural francesa. São Paulo: Graal, 1988.

DASTON, Lorraine; PARK, Katharine. Wonders and the Order of Nature. New York: Zone Books, 1998.

DAVIS, Natalie Zemon. Culturas do povo. Rio de Janeiro: Paz e Terra, 1990.

DAVIS, Natalie Zemon. Sociedade e Cultura na França Moderna. Tradução: Mariza Corrêa. 
Rio de Janeiro: Paz e Terra, 1990.

DEL PRIORE, Mary. Esquecidos por Deus: Monstros no Mundo Europeu e IberoAmericano (Séculos XVI-XVIII). São Paulo: Companhia das Letras, 2000.

EAGLETON, Terry. A ideia de cultura. Tradução: Sandra Castello Branco. São Paulo: Editora Unesp, 2005.

EAGLETON, Terry. Teoria da literatura: uma introdução. Tradução: Waltensir Dutra. São Paulo: Martins Fontes, 2001.

ECO, Umberto. História da feiura. Tradução: Eliana Aguiar. Rio de Janeiro: Record, 2007.

FADINI, Ubaldo; NEGRI, Antonio; WOLFE, T. Charles (Orgs.). Desiderio del mostro - dal circo al laboratorio alla política. Roma: Manifestolibri, 2001.

FERNANDES, Florestan. Mário de Andrade e o folclore brasileiro. In: Ofolclore em questão. São Paulo: Hucitec, 1989.

FRANKLIN, Jeová. Xilogravura popular na literatura de cordel. Brasília: LGE, 2007.

GALVÃO, Ana Maria de Oliveira. Cordel: leitores e ouvintes. Belo Horizonte: Autêntica, 2001.

GIL, José. Monstros. Lisboa: Relógio D’Água Editores, 2006.

GINZBURG, Carlo. "Prefácio", "Sinais: raízes de um paradigma indiciário", e "Ticiano, Ovídio e os códigos da figuração erótica no século XVI”. In: . Mitos, emblemas, sinais: morfologia e história. São Paulo: Cia. das Letras, 1989.

GINZBURG, Carlo. O Queijo e os Vermes. São Paulo: Companhia das Letras, 1998.

GRAMSCI, Antonio. Os intelectuais e a organização da cultura. Tradução: Carlos Nelson Coutinho. Rio de Janeiro: Civilização Brasileira, 1968.

GRANGEIRO, Cláudia Rejanne Pinheiro. O discurso religioso na literatura de cordel de Juazeiro do Norte. Crato: A Província Edições, 2002. 
HOUAISS, Antônio (Ed.). Dicionário Eletrônico Houaiss da Língua Portuguesa. Rio de Janeiro: Objetiva, 2001.

HUET, Marie-Helene. Monstruous imagination. Cambridge: Harvard University Press, 1993.

JEHA, Júlio. (Org.). Monstros e monstruosidades na literatura. Belo Horizonte: Editora da UFMG, 2007.

KAYSER, Wolfgang. O grotesco: configuração na pintura e na literatura. São Paulo: Perspectiva, 2003.

KUNZ, Martine. Cordel: a voz do verso. Fortaleza: Museu do Ceará, 2001. MARANHÃO, Liêdo. O folheto popular - sua capa e seus ilustradores. Recife: Massangana, 1981.

LÉVI-STRAUSS, Claude. Mito e significado. Tradução:António Marques Bessa. Lisboa: Edições 70, 1979.

LÉVI-STRAUSS, Claude. O homem nu. Mitológicas IV. Tradução: Beatriz Perrone-Moisés. São Paulo: Cosac Naify, 2011.

LOOK, Brandon C. Leibniz and Locke on Natural Kinds. In: Branching Off:

The Early Moderns in Quest for the Unity of Knowledge. Bucarest: Zeta Books, 2009.

LUNA E SILVA, Vera Lúcia de. Primórdios da literatura de cordel no Brasil - Um folheto de 1865. Revista Graphos, João Pessoa, v. 12, n. 2, dez. 2010.

ORTIZ, Renato. Românticos e folcloristas. São Paulo: Olho d'água, 1992.

PASTA JÚNIOR, José Antônio. Cordel, intelectuais e o Divino Espírito Santo (notas sobre artes do povo e estética da representação). In: BOSI, Alfredo (Org.). Cultura Brasileira temas e situações. São Paulo: Ática, 2006. p. 58-74.

PELOSO, Silvano. O canto e a memória. História e utopia no imaginário popular brasileiro. São Paulo: Ática, 1996. 
PROENÇA, Manoel Cavalcanti (Org.). Literatura popular em verso: antologia. Belo Horizonte: Itatiaia/ São Paulo: Edusp/ Rio de Janeiro: Fundação Casa de Rui Barbosa, 1986.

RAMOS, Ana Margarida. Os monstros na literatura de cordel portuguesa do século XVIII. Lisboa: Edições Colibri, 2008.

RAMOS, Everardo. Do mercado ao museu: a legitimação artística da gravura popular. In: Visualidades (UFG), Goiânia, v. 8, p. 39-57, 2010. Disponível em: http://www.revistas.ufg.br/index.php/VISUAL/article/view/18209/10865. Acesso em: 07 jan. 2016.

RAMOS, Everardo. Veredas no Grande Sertão: aportes da História da Arte para o estudo da criação popular. In: VII ENCONTRO DE HISTÓRIA DA ARTE - UNICAMP, VII, Campinas, 2011. p. 145.

RAMOS, Everardo. Escritores-illustradores de folhetos de cordel: processos de criação popular. In: ENCONTRO REGIONAL DA ABRALIC (USP), São Paulo, 2007.

RAMOS, Everardo. Du marché au marchand. La gravure populaire bresilienne. Éditions Musée de Gravelines, 2005.

RAMOS, Francisco Régis Lopes. O verbo encantado. A construção do Padre Cícero no imaginário dos devotos. Ijuí: Unijul, 1998.

RIBEIRO, P. Nos caminhos do repente. Teresina: Halley Gráfica e Editora, 1995.

ROAZZI, Antoni. Saberes sobre o fazer: representações sociais de repentistas sobre o repente. In: II ENCONTRO DE PESQUISA EM EDUCAÇÃO DA UFPI: FORMAÇÃO DE PROFESSORES, DIREITOS HUMANOS E DIVERSIDADES CULTURAIS, Teresina, 2002.

SOUTO MAIOR, Mário. Painel Folclórico do Nordeste. Recife: Editora Universitária, 1981.

SOUZA, Laura de Mello e. O diabo na terra de Santa Cruz: feitiçaria e religiosidade popular no Brasil colonial. São Paulo: Cia. das Letras, 1993. 
TAUNAY, Visconde de (Afonso D'escragnolle Taunay) (Org.); PRIORE, Mary Del. Monstros e monstrengos do Brasil. São Paulo: Companhia das Letras, 2011.

TERRA, Ruth Brito Lemos. Memória de lutas: primórdios da literatura de folhetos do Nordeste (1893-1930). São Paulo: Global, 1983.

THOMPSON, Edward Palmer. A Formação da Classe Operária Inglesa. 1. v. Rio de Janeiro: Paz e Terra, 1987.

THOMPSON, Edward Palmer. Costumes em comum. São Paulo: Companhia das Letras, 2013.

VELOSO, Mariza; MADEIRA, Angélica. Leituras brasileiras - itinerários no pensamento social e na literatura. São Paulo: Paz e Terra, 1999.

WILLIAMS, Raymond. Cultura e sociedade. São Paulo: Companhia Editora Nacional, 1969. 


\subsection{Cordéis}

A pesquisa procurou identificar todos os autores, xilógrafos e editores relacionados aos cordéis que compuseram o corpos. Ainda que especificidades do próprio material não tenham possibilitado a identificação plena dos responsáveis, todos os esforços foram feitos para que se cumprissem os direitos de propriedade legal e intelectual sobre os folhetos, tratados igualmente com imenso respeito.

ANDRADE, J. J. A moça que virou cachorra porque deu banana ao padre frei Damião. S.1.: s.n., 19--. (Coleção Ruth Terra).

BANDEIRA, Pedro. A mulher que virou cobra por zombar de Frei Damião. Juazeiro do Norte: s.n., 19--.

BARROS, João A. de Bebê diabo apareceu em São Paulo. S.l.: s.n., 19--. (Acervo Raymond Cantel).

BARROS, João A. de. História de um peru que falou ou um peru malicioso. S.1.: s.n., 19--. (Coleção Ruth Terra).

BARROS, João A. de. O velho caipora. Recife: Editorial Novo Horizonte, 19--. (Coleção Ruth Terra).

BARROS, João A. de. Os primogênitos do rapaz que casou com uma porca, ou a porcaria de Romeu. Recife: s.n., circa 1950.

BARROS, João Antonio de. Encontro da crente que virou besta com o crente que virou jumento. Recife: s.n., 19--. (Coleção Ruth Terra).

BARROS, João Antonio de. Mensageira do diabo ou a mulher vampiro. Recife: s.n., 19--. 
(Coleção Ruth Terra).

BARROS, João Antonio de. O rapaz que virou cachorro porque zombou do Padre Cícero Romão. Juazeiro do Norte: s.n., 19--.

BARROS, Leandro Gomes. História de Juvenal e o dragão. Juazeiro do Norte: Tipografia São Francisco, 19--.

BATISTA, Abraão. A luta de um homem com um lobisomem. Juazeiro do Norte: s.n., 19--.

BATISTA, Abraão. Conversa da caapora com o saci pererê. Juazeiro do Norte: s.n., 1992. (Coleção Gilmar de Carvalho).

BATISTA, Abraão. O fenômeno do bode que nasceu metade gente metade bode. Juazeiro do Norte: s.n., 1975. (Acervo Raymond Cantel).

BATISTA, Abraão. O menino Monstro. Juazeiro do Norte: Tipografia São Francisco, 1970. (Acervo Raymond Cantel).

BATISTA, Abraão. O menino que nasceu com o coração do lado de fora. Juazeiro do Norte: Tipografia São Francisco, 1976. (Acervo Raymond Cantel).

BATISTA, Abraão. O papa-figo. Juazeiro do Norte: s.n., 1974.

BATISTA, Abraão. O pássaro encantado da gruta do Ubajara. Juazeiro do Norte: s.n., 1978.

BORGES, José Francisco. A moça que virou jumenta porque falou de top less com Frei Damião. Bezerros: s.n., 19--. (Coleção Gilmar de Carvalho).

BORGES, José Francisco. A mulher vampiro e o exemplo das costas nuas. Bezerros: Ed. Prop. José Francisco Borges, 19--. (Coleção Ruth Terra).

BRANDÃO, Petrolin. Romance da peteleca. Salvador: s.n., 1972.

CALDAS, João Bandeira de. A cobra de dois chifres da lagoa encantada da Timbaúba. S.1.: s.n., 19--. (Coleção Gilmar de Carvalho).

CAMPINA, Manoel A. Epaminondas e o monstro da gruta d'água. S.1.: s.n., 19--. (Acervo 
Raymond Cantel).

CARVALHO, José Furtado de. O cavaleiro da lua e o dragão do pôr do sol. S.1.: s.n. 1999. (Coleção Gilmar de Carvalho).

CAVALCANTE, Rodolfo Coelho. A criança que nasceu com duas cabeças e três braços em Pernambuco. Jequié: s.n., 19--. (Acervo Raymond Cantel).

CAVALCANTE, Rodolfo Coelho. A moça que bateu na mãe e virou cachorra. Salvador: Ed. Prop. Rodolfo Coelho Cavalcante, 1973. (Acervo Raymond Cantel).

CAVALCANTE, Rodolfo Coelho. A mulher que deu a luz a uma cobra porque zombou do Bom Jesus da Lapa. Salvador: Agência de Folhetos, 1976. (Acervo Raymond Cantel.).

CAVALCANTE, Rodolfo Coelho. Menino de dois mêses que está falando em Pernambuco. . S.1.: s.n., 19--. (Coleção Ruth Terra).

CAVALCANTE, Rodolfo Coelho. O boi de sete chifres. Salvador: s.n., 19--. (Acervo Raymond Cantel).

CAVALCANTE, Rodolfo Coelho. O filho que levantou falso a mãe e virou bicho. Salvador: Tipografia Ansival,1977. (Acervo Raymond Cantel).

CAVALCANTE, Rodolfo Coelho. O rapaz que bateu na mãe e virou bicho em Feira de Santana. 6. ed. S.1.: Ed. Prop. Rodolfo Coelho Cavalcante, 1967.

CAVALCANTE; Rodolfo Coelho; SANTOS, Alípio B. dos. A mulher sem cabeça que está aparecendo no nordeste. Salvador: s.n., 1972. (Coleção Ruth Terra).

D'ALMEIDA FILHO, Manoel. O exemplo do menino que nasceu com duas cabeças. S.l.: s.n., 19--. (Acervo Raymond Cantel).

FANKA. Padre Cícero e a Vampira. Sociedade dos cordelistas Mauditos. Juazeiro do Norte: s.n., 2000. (Coleção Gilmar de Carvalho).

FERREIRA, João Melequíades. História do pavão misterioso. Juazeiro do Norte: Filhas de José Bernardo da Silva, 19--. 
FERREIRA, Severino Amorim. Estória da criança que nasceu com quatro braços, quatro pernas e duas cabeças, falou três horas e morreu. S.1.: Manoel Caboclo e Silva, circa 1960. (Acervo Raymond Cantel).

FILHO, João Carneiro. A Moça que Deflorou Duas Moças e Transformou-se em Homem e os Castigos da Terra. Uruóca: s.n., 19--.

GOMES, Paulo de Tarso Bezerra. O rapaz que brigou com o lobisomem. 3. ed. Fortaleza, 1990. (Coleção Gilmar de Carvalho).

GONÇALVES, Antônio (Patativa do Assaré). A lâmpada de Aladim. Juazeiro do Norte: Universidade Regional do Cariri (URCA), Associação de Artistas e Amigos da Arte (AMAR), 1989. (Coleção Ruth Terra).

LEITE, José Costa. O cavalo voador ou Juliêta e Custódio. Fortaleza/Ceará: Tupynanquim Editora, 2005. (Coleção Ruth Terra).

MAXADO, F. O jumento que virou gente ou o milagre do Frei Damião. Olinda: Casa das Crianças de Olinda, 1979. (Acervo Raymond Cantel).

MELO, Vicente Vitorino. História de Luizinho e o velho feiticeiro. Bezerros: Ed. Prop. José Francisco Borges, 19--.

MONTEIRO, José Estácio. Exemplo de um filho que casou com a mãe e virou jumento. Aracaju: Silva, Antonio José da (Folheteiro ambulante), 19--. (Acervo Raymond Cantel).

MOSSORÓ, Antônio Lucena. Um cabeludo que deu a luz a um cururu em Feira de Santana. (FL)

NETO. João Pedro C. Besta do horror. Fortaleza: Ed. do Autor, 2001. (Coleção Gilmar de Carvalho).

OLIVEIRA, José Duda de. Homem que tinha fé em Deus e lutou com um dragão. Fortaleza: Manoel Caboclo e Silva, 1979. (Coleção Gilmar de Carvalho).

OLIVEIRA, Severino Gonçalves de. O menino que nasceu barbado. S.1.: s.n., 19--. (Acervo 
Raymond Cantel.)

PAULA, Arquimedes de. $O$ valor de Reginaldo e o encanto de Jacira. S.1.: s.n., 19--.

PAULINO, Eliseu. O cão da Itaoca, 2010, Coleção Gilmar de Carvalho.

RIBEIRO, Edgley. A mulher que virou Diabo. S.l.: s.n., 1976. (Acervo Raymond Cantel).

RINARÉ, Rouxinol do. O colar de pérolas e a lenda dos vaga-lumes. Fortaleza: Editora Tupynanquim, 2001. (Coleção Gilmar de Carvalho).

ROCHA, José Pacheco da. A princesa Rosamunda ou a morte do gigante. São Paulo: Editora Luzeiro, 1974. (Fundação Casa de Ruy Barbosa).

ROMEU, H. A moça que virou cabra. S.l.: s.n., 19--. (Acervo Raymond Cantel).

RUFINO, H. Rufino. A papa-figo em ação. S.l.: s.n., 19--. (Coleção Ruth Terra).

SALES, F. Exenplo das crianças que nasceram ligas da em Belo Jardim. S.1.: s.n., 19--. (Acervo Raymond Cantel).

SANTANA, Braulio Teixeira. O monstro filho de um casal de irmãos. S.1.: s.n., 1960, (Acervo Raymond Cantel).

SANTOS, Alípio Bispo dos. O ateu que virou monstro na noite de São João. S.l.: s.n., 19--.

SANTOS, Enéas Tavares dos. O encontro de um feiticeiro com a negra de um peito só. Maceió: Museu Theo Brandão, 1977. (Coleção Folclórica da UFAL)

SANTOS, Enéas Tavares. A mulher de quatro metros que anda de feira em feira. S.1.: s.n., 19--. (Coleção Ruth Terra).

SANTOS, José Martins dos. A moça que virou porca. S.1.: s.n., 19--. (Acervo Raymond Cantel).

SANTOS, Vidal; VIANA, Arievaldo. O príncipe das sete capas. Mossoró: Editora QueimaBucha, 2007. (Contos de Cascudo em Cordel). 
SENA, Joaquim Batista de. História de João Valente e o dragão de três cabeças. Fortaleza: Tipografia Casa dos Horóscopos, 19--. (Acervo Raymond Cantel).

SILVA, Expedito F. da. O filho de Juvenal e o dragão vermelho. Rio de Janeiro: s.n., 1978. (Coleção Raymond Cantel).

SILVA, Gilberto Severino da. A menina que nasceu em Minas Gerais, com quatro olhos, duas bocas, duas ventas, quatro orelhas e dez dedos em cada mão, Acervo Raymond Cantel.

SILVA, J. B. O maior exemplo do mundo, o menino que nasceu cabeludo. S.1.: s.n., 19--. (Acervo Raymond Cantel).

SILVA, João José da. A moça que virou cobra. Condado: Ed. Prop. João José da Silva, Coleção Raymond Cantel.

SILVA, João Vicente da. As proesas de bebê diabo que agora pelo mundo anda a procura do pai. S.1.: s.n., 19--. (Acervo Raymond Cantel).

SILVA, José Bernardo da. História do rapaz que virou cavalo. Juazeiro do Norte: Tipografia São Francisco, 1958. (Acervo Raymond Cantel).

SILVA, José Bernardo da. Raquel e a fera encantada. Juazeiro do Norte: Tipografia São Francisco, 1964.

SILVA, José Bernardo. História do boi mandingueiro e o cavalo misterioso. Juazeiro do Norte: Tipografia São Francisco, 1955. (Coleção Ruth Terra).

SILVA, José Bernardo. História do boi misterioso. Juazeiro do Norte: Tipografia São Francisco, 19--. (Coleção Ruth Terra).

SILVA, José Bernardo. História do pato misterioso. Juazeiro do Norte: Tipografia São Francisco, 1955. (Coleção Ruth Terra).

SILVA, José Soares da (Dila). Camões e o rei mágico. Caruaru: Folhetaria São José de Vandecila Silva, 19--. (Acervo Raymond Cantel).

SILVA, José Soares da (Dila). O homem que virou bode. Caruaru: Artfolheto São José de 
Dila, 19--. (Coleção Ruth Terra).

SILVA, José Soares da (Dila). O homem que virou bode. Caruaru: Artfolheto São José, 19-. (Acervo Raymond Cantel).

SILVA, José Soares da (Dila). São Salviano e Satanás. Caruaru: Artefolheto São José, 19--.

SILVA, Manoel Caboclo e. O menino que nasceu com a pintura do cão. Juazeiro do Norte: s.n., 1976. (Acervo Raymond Cantel).

SILVA, Minelvino Francisco da. A mulher de sete metros que apareceu em Itabuna - Estado da Bahia. Itabuna: s.n., 1968. (Coleção Ruth Terra).

SILVA, Minelvino Francisco da. A prisão do gigante da montanha assombrosa. Juazeiro do Norte: José Bernardo da Silva, 1974. (Acervo Raymond Cantel).

SILVA, Minelvino Francisco da. História do bicho de sete cabeças. São Paulo: Editora Luzeiro. (Acervo Raymond Cantel).

SILVA, Minelvino Francisco da. História do gigante da montanha assombrosa. Juazeiro: Filhos de José Bernardo da Silva, 1974. (Acervo Raymond Cantel).

SILVA, Minelvino Francisco da. Os martírios de três irmãs e a tragédia de um pássaro encantado. S.1.: s.n., 19--. (Coleção Ruth Terra).

SOARES, José Francisco. O homem macaco ou o lobisomem do Cabo. Recife: s.n., 19--. (Coleção Ruth Terra).

SOARES, José. A menina fenômeno foi moça com 10 meses, em Arapiraca. S.1.: s.n., 19--. (Coleção Ruth Terra).

SOARES, José. A mulher que deu a luz a um satanás. Recife: s.n., 1975. (Acervo Raymond Cantel).

SOARES, José. Negra de um peito só. Olinda: Casa das Crianças de Olinda, 19--.

SOARES, José. O caranguejo de Várzea Nova. S.1.: s.n., 19--. (Coleção Ruth Terra). 
SOARES, José. O fenômeno dos fenômenos: o rio de São Francisco secando. S.l.: s.n., 19--. (Coleção Ruth Terra).

SOARES, José. O menino que nasceu com a cabeça nas costas. Recife: s.n., 1974. (Acervo Raymond Cantel).

SOARES, José. O monstro de São Paulo. Recife: s.n., 1977.

SOARES, José; CAMPOS, Francisco Souza. Abelhas, morcegos e grilos sugando a humanidade. Recife: s.n., 19--. (Coleção Ruth Terra).

SOUZA, Antonio Patricio de. O bebê Diabo: A história do menino que nasceu com 2 chifres e peludo em São Bernardo do Campo - São Paulo. Campina Grande: Folhetaria Estrela do Oriente, 1975. (Acervo Raymond Cantel).

TAVARES, Cavalcante. A filha amaldiçoada. Fortaleza: Secretaria de Cultura e Desporto, 1990. (Coleção Gilmar de Carvalho).

VENTURA, Manoel Serafim. O protestante que virou num urubu porque queria matar Frei Damião. S.1.: s.n., 19--. (Coleção Ruth Terra).

VIANA, Antônio Klévisson. A história de João e o pé de feijão. Fortaleza: Editora Tupynanquim, 2000. (Coleção Gilmar de Carvalho).

VIANA, Arievaldo; PAULINO, Pedro Paulo. A caveira do ET encontrada em Quixadá. Ceará: Tupynanquim, 2005. (Coleção Gilmar de Carvalho).

VITORINO, Vicente. Exemplo da crente que profanou Frei Damião. S.1.: s.n., 19--. (Coleção Ruth Terra). 